Prepared for the U.S. Department of Energy under Contract DE-AC05-76RL01830

\title{
RESULTS OF THE EXCRETA BIOASSAY QUALITY CONTROL PROGRAM FOR APRIL 1, 2010 THROUGH MARCH 31, 2011
}

\author{
CL Antonio
}

\section{July 2012}




\title{
DISCLAIMER
}

This report was prepared as an account of work sponsored by an agency of the United States Government. Neither the United States Government nor any agency thereof, nor Battelle Memorial Institute, nor any of their employees, makes any warranty, express or implied, or assumes any legal liability or responsibility for the accuracy, completeness, or usefulness of any information, apparatus, product, or process disclosed, or represents that its use would not infringe privately owned rights. Reference herein to any specific commercial product, process, or service by trade name, trademark, manufacturer, or otherwise does not necessarily constitute or imply its endorsement, recommendation, or favoring by the United States Government or any agency thereof, or Battelle Memorial Institute. The views and opinions of authors expressed herein do not necessarily state or reflect those of the United States Government or any agency thereof.

\author{
PACIFIC NORTHWEST NATIONAL LABORATORY \\ operated by \\ BATTELLE \\ for the \\ UNITED STATES DEPARTMENT OF ENERGY \\ under Contract DE-AC05-76RL01830
}

Printed in the United States of America
Available to DOE and DOE contractors from the Office of Scientific and Technical Information,
P.O. Box 62, Oak Ridge, TN 37831-0062;
ph: (865) 576-8401
fax: $(865)$ 576-5728
email: reports@adonis.osti.gov

\begin{abstract}
Available to the public from the National Technical Information Service, U.S. Department of Commerce, 5285 Port Royal Rd., Springfield, VA 22161 ph: (800) 553-6847 fax: $(703) 605-6900$ email: orders@ntis.fedworld.gov online ordering: http://www.ntis.gov/ordering.htm
\end{abstract}

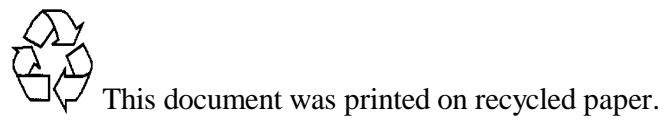




\section{RESULTS OF THE EXCRETA BIOASSAY QUALITY CONTRIL PROGRAM FOR APRIL 1, 2010 THROUGH MARCH 31, 2011}

CL Antonio

July 2012

Prepared for the U.S. Department of Energy under Contract DE-AC05-76RL01830

Pacific Northwest National Laboratory

Richland, Washington 99352 


\title{
RESULTS OF THE EXCRETA BIOASSAY QUALITY CONTROL PROGRAM FOR APRIL 1, 2010 THROUGH MARCH 31, 2011 CONTRACT 112512
}

\author{
Cheryl L. Antonio
}

April 2012

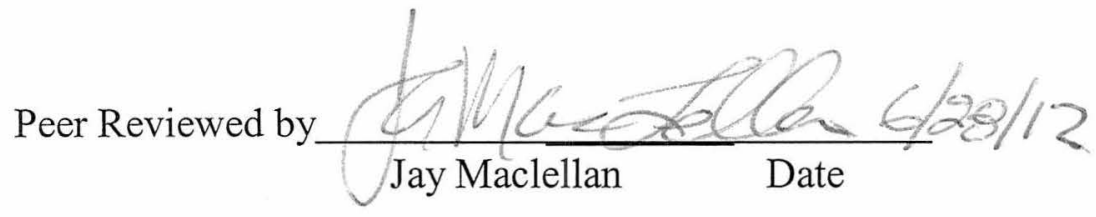




\section{$\underline{\text { SUMMARY }}$}

A total of 76 urine samples and 10 spiked fecal samples were submitted during the report period (April 1, 2010 through March 31,2011) to GEL Laboratories, LLC in South Carolina by the Hanford Internal Dosimetry Program (IDP) to check the accuracy, precision, and detection levels of their analyses. Urine analyses for ${ }^{14} \mathrm{C}, \mathrm{Sr}$, for ${ }^{238} \mathrm{Pu},{ }^{239} \mathrm{Pu},{ }^{241} \mathrm{Am}$, ${ }^{243} \mathrm{Am},{ }^{235} \mathrm{U},{ }^{238} \mathrm{U},{ }^{238} \mathrm{U}$-mass and fecal analyses for ${ }^{241} \mathrm{Am},{ }^{238} \mathrm{Pu}$ and ${ }^{239} \mathrm{Pu}$ were tested this year. The number of QC urine samples submitted during the report period represented $1.1 \%$ of the total samples submitted.

In addition to the samples provided by IDP, GEL was also required to conduct their own QC program, and submit the results of analyses to IDP. About 31\% of the analyses processed by GEL during the first year of contract 112512 were quality control samples. GEL tested the performance of 23 radioisotopes, all of which met or exceeded the specifications in the Statement of Work within statistical uncertainty except the slightly elevated relative bias for ${ }^{243,244} \mathrm{Cm}$ (Table 4).

IDP concluded that GEL was performing well for all analyses tested, and concerns identified earlier were satisfactorily resolved (see section on Follow-up on Concerns During the Fifth Contract Year).

Beginning in May 2006, it was decided to evaluate the MDA capability of the Lab based on detections of samples spiked at the $\mathrm{CL}$ level rather than on blanks, with the exception of ${ }^{238} \mathrm{Pu}$ and ${ }^{243} \mathrm{Am}$. The decision not to submit blank samples, other than for ${ }^{238} \mathrm{Pu}$ and ${ }^{243} \mathrm{Am}$, was made in order to increase the number of samples spiked at the CL and therefore improve the statistics for evaluating MDA, bias and precision. The MDA criteria would be met if less than 20 percent of the reported results for samples spiked at the Contractual Detection Level are less than the decision level (for $n$ between 5 and 25) or less than 10 percent of the reported results are less than the decision level (for $\mathrm{n}>25$ ).

The isotopic uranium analysis reports on three uranium isotopes: ${ }^{234} \mathrm{U},{ }^{235} \mathrm{U}$, and ${ }^{238} \mathrm{U}$. The isotopes are differentiated only during counting by alpha spectrometry. All performance criteria were met within statistical variation. Of the 89 samples that GEL spiked at the CDL, only two samples did not show detection, giving a false-negative (beta error) of $2 \%$, which was acceptable.

Because IDP used a depleted uranium source material for the isotopic uranium urinalyses, ${ }^{233,234} \mathrm{U}$ was not evaluated. However, the performance statistics for ${ }^{235} \mathrm{U}$ and ${ }^{238} \mathrm{U}$ were reviewed and the MDA for ${ }^{235} \mathrm{U}$ and the bias and precision for ${ }^{238} \mathrm{U}$ were acceptable.

No concerns were identified with the ${ }^{238} \mathrm{U}$ mass urinalysis program using inductivelycoupled plasma mass spectrometry (ICPMS) and it was considered acceptable. Because IDP uses a $0.2 \mu \mathrm{g}$ screening level for ${ }^{238} \mathrm{U}$ mass, samples spiked at $0.06 \mu \mathrm{g}$ were discontinued. The MDA at the contractual level of $0.06 \mu \mathrm{g}$ was evaluated through GEL's program and was found to be acceptable. The relative bias and precision were likewise acceptable. The bias and precision as tested by IDP met the acceptance criteria. The bias and precision was tested by IDP at $0.2 \mu \mathrm{g}$ and by GEL at $1 \mu \mathrm{g} / \mathrm{sample}$ and at $0.05 \mu \mathrm{g} / \mathrm{sample}$.

The performance statistics for the ${ }^{236} \mathrm{U}$ analysis using ICPMS were supplied by GEL's QC program, IDP did not submit QC samples. The MDA and relative bias and precision reported by GEL met the performance criteria. The ${ }^{236} \mathrm{U}$ analysis procedure was considered acceptable. 
The total strontium procedure is used to screen samples to determine whether analysis for ${ }^{90} \mathrm{Sr}$ is warranted. Samples with total strontium results less than $15 \mathrm{dpm}$ do not undergo further analysis. Samples with results greater than or equal to $15 \mathrm{dpm}$ may undergo ${ }^{90} \mathrm{Y}$ ingrowth to specifically determine ${ }^{90} \mathrm{Sr}$ levels. The calculated MDA, reported by GEL and tested by IDP, for the total strontium part of the analysis was less than $46 \%$ of the CL. The MDA, relative bias and precision, tested by IDP and GEL for the ${ }^{90} \mathrm{Sr}$ and total $\mathrm{Sr}$ procedures were all within limits. The relative bias was slightly elevated but within statistical uncertainty. The 16 samples spiked at the contractual level by IDP were all detected. The strontium urinalysis procedure was concluded to be acceptable.

Samples spiked with ${ }^{238} \mathrm{Pu}$ and ${ }^{239} \mathrm{Pu}$ were analyzed using the same procedures and same reagents. The two isotopes are differentiated only at the end of the procedure by alpha spectrometry. Therefore, laboratory performance is expected to be similar for both isotopes using any of the seven procedures that incorporate plutonium analysis (IPU, IPA, IPS, IPSA, IPSR, IUPU, and ITPAC).

The MDAs and performance statistics for ${ }^{239} \mathrm{Pu}$ and ${ }^{238} \mathrm{Pu}$ in urine were acceptable. The MDA tested by IDP was slightly above the CDL, but the difference was not considered significant because only three results were submitted. The MDA tested by GEL and based on 557 samples was $25 \%$ less than the criteria. The 14 samples spiked at the CL for ${ }^{239} \mathrm{Pu}$ all showed detection and the relative bias and precision met the acceptance criteria. Out of 555 samples spiked by GEL at the CDL, only 2 samples did show detection, giving a false-negative (beta error) of $0.4 \%$, which was acceptable. There were 17 blank samples analyzed for ${ }^{238} \mathrm{Pu}$ activity, none of the 17 samples detected activity in excess of the decision level. Overall the plutonium urinalyses were considered acceptable.

The MDA and performance statistics for ${ }^{239} \mathrm{Pu}$ and ${ }^{238} \mathrm{Pu}$ in feces were likewise acceptable. More than $15 \%$ of the fecal samples analyzed were duplicated to test the consistency of the aliquoting procedure. A review of the duplicate samples determined that the aliquoting procedure produced results with a variation of less than 3 sigma. The fecal aliquoting procedure was acceptable. This year IDP submitted 10 actual fecal samples, five samples were blanks and five samples were spiked with very insoluble ${ }^{239} \mathrm{Pu}$ and slightly soluble ${ }^{238} \mathrm{Pu}$. The MDA, precision and bias for ${ }^{239} \mathrm{Pu}$ and ${ }^{238} \mathrm{Pu}$ met the performance criteria. The performance statistics reported by GEL for ${ }^{239} \mathrm{Pu}$ and ${ }^{238} \mathrm{Pu}$ also met the acceptance criterion. The failed analysis rate for fecal sampling was $1 \%$ with a low or high yield rate of $7 \%$, which is within the contractual level of $10 \%$. Overall the plutonium fecal analyses were considered acceptable but the failed analysis rate will continue to be monitored.

The ${ }^{241} \mathrm{Am}$ fecal and urine analyses met the acceptance criteria for MDA, relative bias and precision. The MDA tested by IDP was slightly above the CDL, but the difference was not considered significant because only three results were submitted. The MDA as reported by GEL was less than $10 \%$ of the contractual level. All 14 of the ${ }^{241} \mathrm{Am}$ samples spiked at the contractual detection level (CDL) were detected. Out of 280 samples spiked by GEL at the CDL, only three samples did not show detection, giving a false-negative (beta error) of $1 \%$, which was acceptable. The relative bias and precision as reported by GEL and tested by IDP met the performance criteria. The current AM241 urinalysis procedure was considered acceptable.

The ${ }^{241}$ Am fecal duplicate samples were evaluated and it was concluded that the aliquoting procedure produced results with a variation less than three sigma. This year IDP submitted five 
actual fecal samples spiked with very insoluble ${ }^{241} \mathrm{Am}$ and the relative bias and precision were acceptable. Overall the ${ }^{241} \mathrm{Am}$ fecal analyses were considered acceptable.

The AM243 procedure was identical to the AM241 procedure, except a different tracer is used $\left({ }^{244} \mathrm{Cm}\right.$ instead of $\left.{ }^{243} \mathrm{Am}\right)$. The four blank ${ }^{243} \mathrm{Am}$ QC samples submitted were all reported with results less than the decision level, and the calculated MDA met the contractual detection level. The performance statistics for ${ }^{243} \mathrm{Am}$, as tested by GEL, met the acceptance criteria for relative bias and precision. The MDA was slightly elevated, but was within the statistical uncertainty of the analysis. The ${ }^{243} \mathrm{Am}$ procedure was concluded to be acceptable.

IDP did not submit QC samples to test the isotopic curium program, therefore performance statistics were based on the GEL QC results. GEL tested the MDA for ${ }^{242} \mathrm{Cm}$ and ${ }^{244} \mathrm{Cm}$ and the relative bias and precision for ${ }^{244} \mathrm{Cm}$. The average relative bias of ${ }^{244} \mathrm{Cm}$ was slightly elevated but it was not considered a concern (see Table 4). Overall the results met the acceptance criteria and the isotopic curium urinalysis program was considered acceptable.

IDP also did not submit QC samples to test the isotopic thorium program, therefore performance statistics were based on the GEL QC results. GEL tested the MDA for ${ }^{228} \mathrm{Th},{ }^{229} \mathrm{Th}$, ${ }^{230} \mathrm{Th}$ and ${ }^{232} \mathrm{Th}$ and the relative bias and precision for ${ }^{232} \mathrm{Th}$. Of the 12 samples spiked with ${ }^{232} \mathrm{Th}$, one sample did not show detection, resulting in a false-negative percent (beta error) of $8 \%$, which was determined to be acceptable, assuming the normal statistical variation in the measurement process. Overall the results met the acceptance criteria and the isotopic thorium urinalysis program was considered acceptable.

Neptunium-237 was likewise not tested by IDP and the performance statistics were supplied by the GEL's QC program. The MDA, average relative bias and precision met the performance criteria and the NP237 analysis was considered acceptable.

Because GEL LLC, did not meet the acceptance criteria for C14 urinalyses under the guidelines set forth by the Department of Energy's Laboratory Accreditation Program (DOELAP), IDP submitted 12 samples for analysis to further test the procedure. Five blank samples and 12 spiked samples were submitted and the MDA, average relative bias and precision all met IDP's contractual specifications. After reviewing the ${ }^{14} \mathrm{C}$ source material on the Hanford Site, IDP determined that ${ }^{14} \mathrm{C}$ bioassay monitoring would not be required and pursuing DOELAP accreditation for the procedure was discontinued. This is discussed further in the Carbon-14 section. 


\section{CONTENTS}

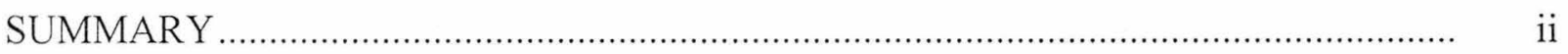

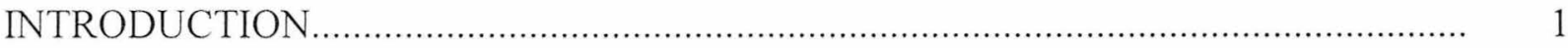

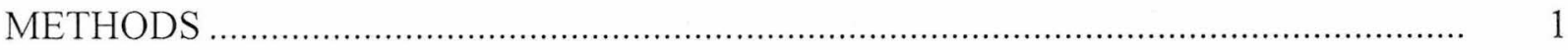

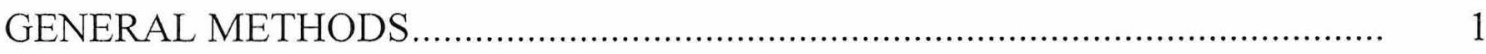

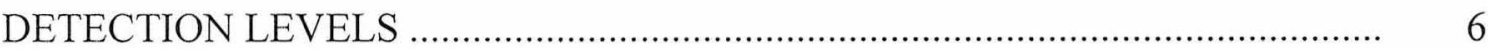

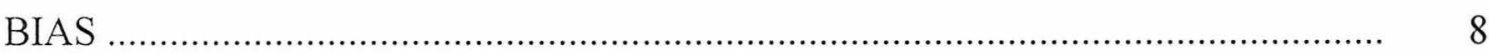

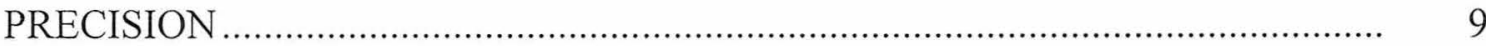

FINDINGS

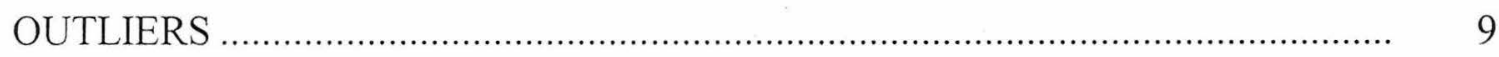

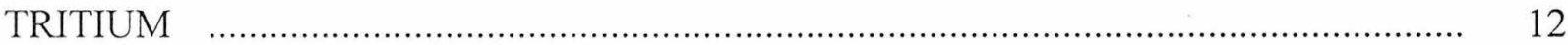

STRONTIUM-90 AND TOTAL STRONTIUM ........................................................... 12

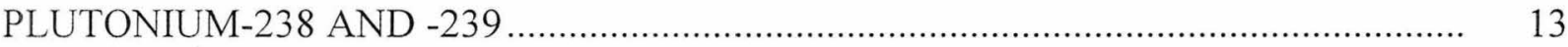

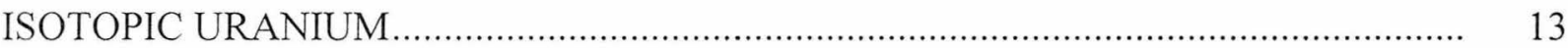

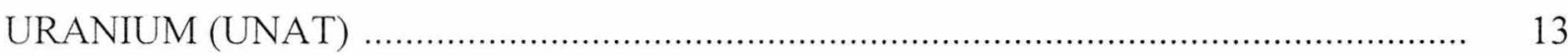

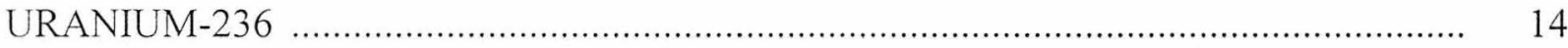

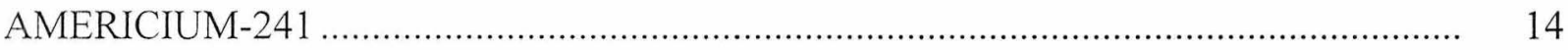

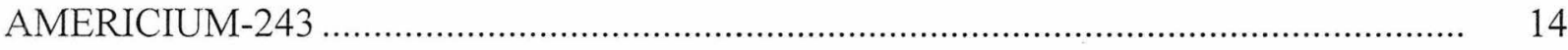

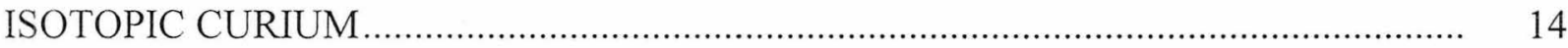

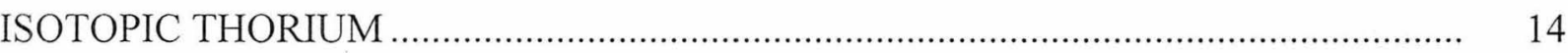

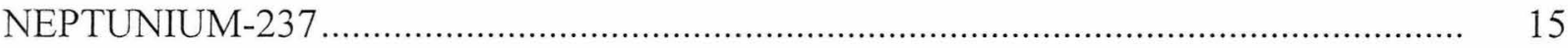

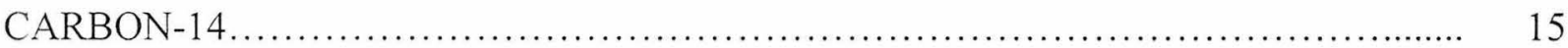

FOLLOW-UP ON FINDINGS FROM FIFTH YEAR CONTRACT YEAR .................... 15

SUMMARY OF THE QUALITY CONTROL REPORT FROM GEL INCORPORATED, FOR THE CONTRACT 112512 FIRST OPERATIONAL YEAR .................................. 16

RESULTS FROM INTERCOMPARISON PROGRAMS ................................... 16 


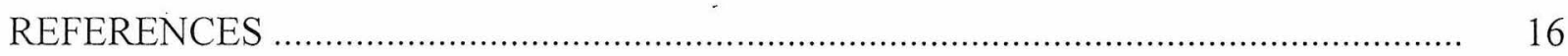

RELEVANT PROCEDURES AND CORRESPONDENCE …....................................... 18

ATTACHMENT 1: CARBON-14 FOLLOW-UP

APPENDIX A QUALITY CONTROL SAMPLE RESULTS

(Historical File Only)

APPENDIX B GEL QUALITY CONTROL REPORT SUMMARY

(Historical File Only)

APPENDIX C GEL QUALITY CONTROL INTERCOMPARISON RESULTS

(Historical File Only)

\section{TABLES}

1 Analytical and Reporting Requirements for Routine Processing of Samples ......... 3

$2 \quad$ Number and Category of Bioassay Samples Analyzed ......................................... 5

3 Typical Chemical Yield, Typical Detector Efficiencies, and Counting Time Values from GEL Quality Control Report ................................................................. 8

4 Summary of Statistical Values by Nuclide ............................................................. 10

5 Comparison of Quality Control Statistics Between the Third and Fourth Contract Year with Gel Using QC Samples Submitted by IDP …............................................... 11

$6 \quad$ Other Indicators of Analytical Uncertainty ..................................................... 12 


\section{INTRODUCTION}

This report summarizes the results of the excreta bioassay quality control program's monitoring of the performance of GEL Laboratories, LLC (GEL) for samples submitted from April 1, 2010 through March 31, 2011 under contract 112512. During the reporting period GEL analyzed, under the contract with Battelle, 7455 urine and 96 fecal samples for various radionuclides. The number of samples analyzed was much greater than in previous years due to an increased work force due in part to the American Recovery Act.

The results of the analyses are part of a system of legal records concerning internal deposition of radionuclides for workers at the Hanford Site. GEL is required to have a rigorous quality control $(\mathrm{QC})$ program to ensure the accuracy of its results. In addition, the Pacific Northwest National Laboratory's (PNNL) Hanford Internal Dosimetry Program (IDP) has a QC program in place to independently check the accuracy of the results from GEL. The objective of the PNNL excreta bioassay QC program is to provide quantitative data to support the assessment of performance criteria for excreta bioassay analyses, as specified in the Statement of Work (Battelle 2010).

The reliability of the excreta bioassay program depends, to a significant extent, on the adoption and implementation of performance criteria for laboratory accuracy, precision, and detection levels. Such performance criteria are established in the Statement of Work (Battelle 2010) and include the following:

- Actual minimum detectable activities (MDAs) determined from QC samples for the year shall be equal to or less than the contractual detection level (CL) in the Statement of Work, as calculated from blank QC samples.

- The mean relative bias, $\mathrm{B}_{\mathrm{r}}$, shall fall within $\pm 20 \%$ when calculated from 15 to 50 samples spiked at greater than three times the CL, and within $\pm 10 \%$ when calculated from greater than 50 samples.

- The relative precision statistic, $\mathrm{S}_{\mathrm{B}}$, shall be less than or equal to 0.4 for samples spiked at greater than three times the CL, and less than or equal to 0.5 for samples spiked between one and three times the CL.

Formulas for MDA, $\mathrm{B}_{\mathrm{r}}$, and $\mathrm{S}_{\mathrm{B}}$, presented in the next section of this report, are based on recommendations in the Health Physics Society (HPS) Standard N13.30 (1996) and are listed in the Statement of Work. In addition to the Statement of Work (SOW) performance criteria, it is expected that the MDA shall also be such that fewer than $10 \%$ of the QC samples spiked at the $\mathrm{CL}$ shall be reported with values less than the decision level (i.e., twice the total propagated uncertainty of the result).

\section{METHODS}

\section{GENERAL METHODS}

Urine collected from PNNL employees who are not occupationally exposed to radioactive material was prepared in the 325 Building as blank and spiked samples by PNNL Radiochemical Processing Group (RPG), according to the directions given by the PNNL Internal Dosimetry 
Program (IDP), following Procedure PNL-MA-565-800-20, Rev. 2. Most samples were submitted as double-blind samples, with the exception of isotopic uranium urinalyses and the spiked fecal samples. Double blind samples are scheduled with and collected by GEL as if they were personnel samples. The isotopic uranium urinalyses were scheduled as single-blind intercomparisons, which meant that GEL was aware they were intercomparison samples but unaware of the activity. The samples were scheduled as single-blinds because they were spiked with a depleted uranium source. Since depleted uranium exposures at Hanford are rare, the intercomparison samples would stand out and the QC alias names used could become known and compromise the double-blind intercomparison program. The spiked fecal samples were artificial fecal samples consisting of a soil matrix. Blank fecal samples were scheduled as double-blind samples and were actual fecal samples. GEL analyzed urine samples for tritium, ${ }^{90} \mathrm{Sr},{ }^{14} \mathrm{C},{ }^{237} \mathrm{~Np},{ }^{242} \mathrm{Cm},{ }^{244} \mathrm{Cm},{ }^{238} \mathrm{Pu},{ }^{239,240} \mathrm{Pu}$, ${ }^{241} \mathrm{Pu},{ }^{241} \mathrm{Am},{ }^{243} \mathrm{Am},{ }^{228} \mathrm{Th},{ }^{229} \mathrm{Th},{ }^{230} \mathrm{Th},{ }^{232} \mathrm{Th},{ }^{236} \mathrm{U},{ }^{234} \mathrm{U},{ }^{235} \mathrm{U},{ }^{238} \mathrm{U}$ (alpha spectrometry and mass analysis) and fecal samples for ${ }^{14} \mathrm{C},{ }^{238} \mathrm{Pu},{ }^{239,240} \mathrm{Pu},{ }^{241} \mathrm{Am},{ }^{234} \mathrm{U},{ }^{235} \mathrm{U},{ }^{238} \mathrm{U}$. To reduce costs in the intercomparison program, plutonium, americium, and strontium analyses were tested using routine sequential procedures when possible (i.e., where one urine sample is analyzed for several radionuclides). The analysis categories specified in the contract with GEL are shown in Table 1. All urinalysis samples contained approximately $1000 \mathrm{ml}$ of urine, except for the samples analyzed for tritium, which contained approximately $100 \mathrm{ml}$. GEL's QC sample total is dependent on the number of analytical batches run during the year, and they were well over the $15 \%$ criteria specified in the contract. 
Table 1: Battelle Contract 112512 - Feb. 2010

TABLE B-3

Analytical And Reporting Requirements For Routine Processing Of Samples

Constituents Reported
Pu-238, Pu-239, 240
Pu-238, Pu-239, 240
Am-241
Am-243
Cm-242, Cm-244
U-234, U-235, U-238
Th-228, Th-229, Th-230, Th-232
Np-237
H-3
Sr (sum Sr-89+Sr-90)
Sr-90
K-40, Cs-137+Others
Am-24)
U-236
U-238

\begin{abstract}
Contractual Detection

$$
\text { Level }{ }^{\text {(a) }} \text { (dpm/sample) }
$$
\end{abstract}

Analysis (Code)

Pu(x) isotopic (IPU)

$\mathrm{Pu}(\infty)$ Isotopic (IPUL.)

Am-241 (AM241)

Am-243 (AM243)

$\mathrm{Cm}(\alpha)$ Isotopic (ICM)

$U(\infty)$ Isotopic (IU)

$\mathrm{Th}(\infty)$ Isotopic (ITH)

Np-237 (NP237)

Tritium ( $\mathrm{H} 3)$

Sr-total (SR)

Sr-90 (SR90) $)^{(n)}$

Gamma Spectroscopy (ISPEC)

Gamma Spectroscopy (LEPD)

U-236 Mass (U 236)

U-238 Mass (U 238)

Pm-147 (PM147)

$\mathrm{Pm}-147$

Urine Fecal says following

0.02

0.005

0.02

0.02

0.02

0.1

0.02

$10 \mathrm{dpm} / \mathrm{ml}$

10

10

See
Table B-5

5

0.000140

$0 . \mathrm{g} / \mathrm{sample}(\mathrm{g})$
0.06

0.06 isample
Hgisan

$50 \quad 200$
Reporting Time $e^{(n)}$

Emall
By chose of

business on

day of

determination

Written

Within five Within 10

usiness days business

determination determination
Email Reporting Limit; (dpm/sample) ${ }^{\text {tb) }}$

Urine Focal Eq. 1 Eq. 1

Eq. 1

Eq. 1

Eq. 1 Eq. 1

Eq.

(d)

Eq. 1 Eq.

Eq. 1

$10 \mathrm{dpm} / \mathrm{ml}$

5

Eq. 1

Eq. 1

$70 \mathrm{pg} / \mathrm{sample}$

$0.2 \mu g$ sample

Eq. 1

Sequential Analyses:

$\mathrm{Pu}(\infty)$ Iso and Sr-total (IPS)

$P \cup(\infty)$ iso. Am-241 (IPA)

As for individual analyses

Pu $(\infty)$ iso, Am-241, Sr-total (IPSA)

$P(\infty)$ Iso, U-238 (IUPU)

Aclinide $(\infty)$ isotopic (ITPAC) ${ }^{(h)}$

$\mathrm{Cm}(\alpha)$ iso, Am-241 (ICA) CMm-242, Cm-244, Am-241 ${ }^{(\mathrm{Cl})}$

$\mathrm{PU}(\propto)$ Iso and $\mathrm{U}$ ISO (IPIU)

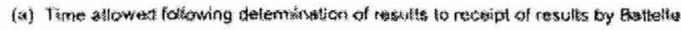

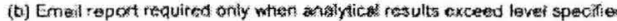

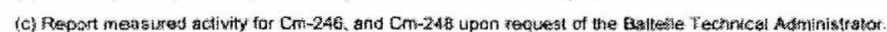

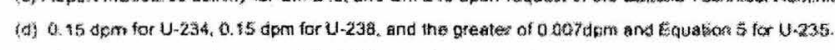

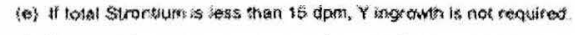

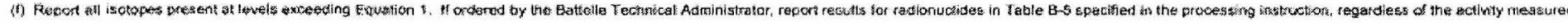

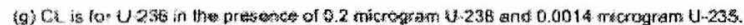

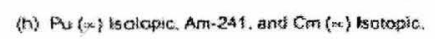


Table 1 cont: Table B-3: Effecitve 1/7/2009

Analytical and Reporting Requirements for Routine Processing of Samples

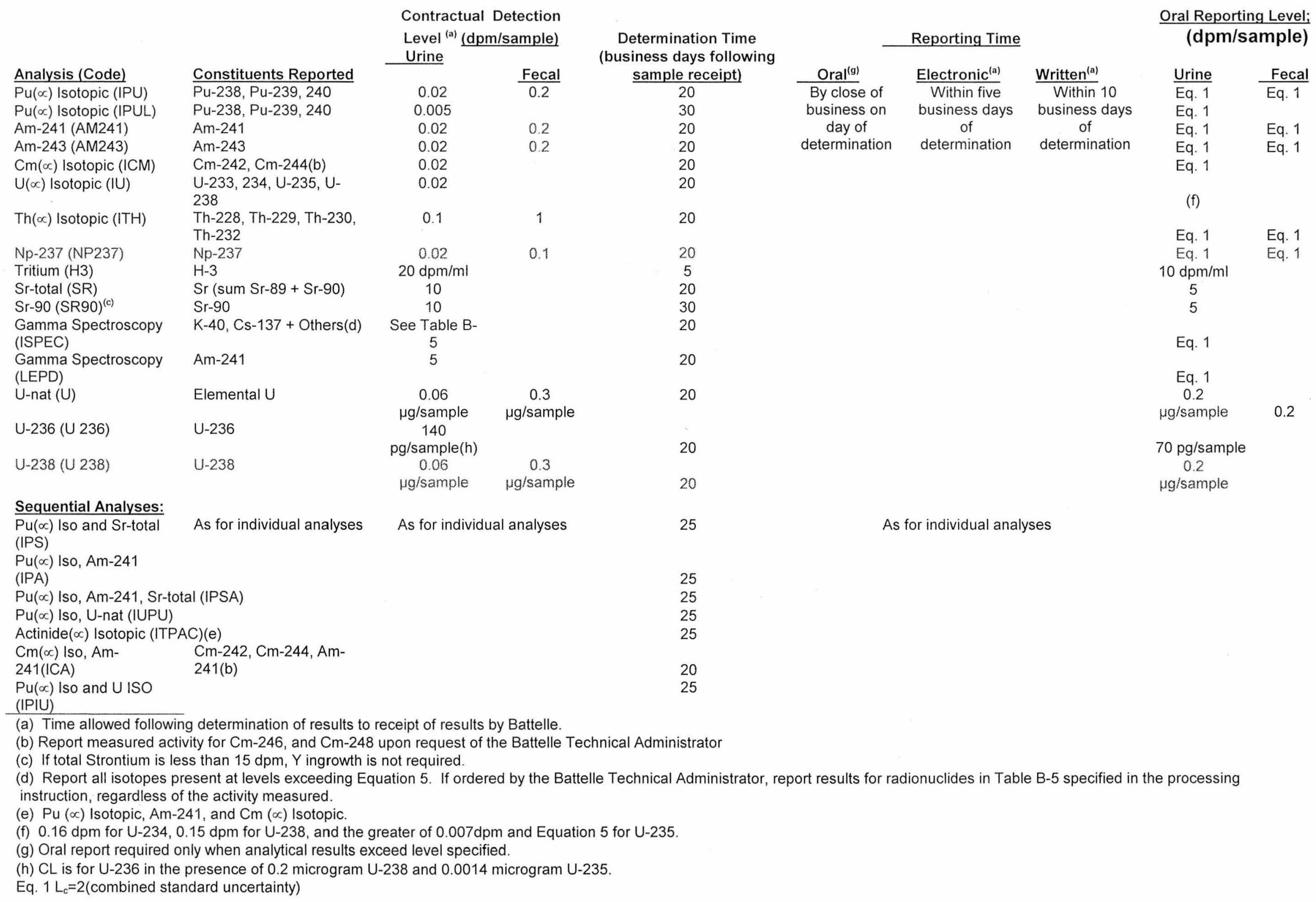


TABLE 2. Number and Category of Bioassay Samples Analyzed

FIFTH CONTRACT (11530) YEAR - FIRST CONTRACT (112512) YEAR GEL

\begin{tabular}{|c|c|c|c|c|c|c|c|c|}
\hline \multirow{2}{*}{$\begin{array}{l}\text { Procedure } \\
\text { Code }^{(\mathrm{a})} \\
\end{array}$} & \multicolumn{4}{|c|}{ 4/1/09 through $3 / 31 / 10$} & \multicolumn{4}{|c|}{ 4/1/10 through $3 / 31 / 11$} \\
\hline & $\begin{array}{c}\text { Tota } \\
1 \\
\end{array}$ & IDP QC & $\%$ & GEL QC $^{(b)}$ & Total & IDP QC & $\%$ & $\mathrm{GEL} \mathrm{QC}^{(\mathrm{b})}$ \\
\hline \multicolumn{9}{|l|}{ Urine } \\
\hline $\mathrm{H} 3$ & 1285 & 0 & -- & 388 & 234 & 0 & -- & 148 \\
\hline $\begin{array}{l}\text { SR90, } \\
\text { SR }\end{array}$ & 406 & 0 & -- & 882 & 293 & 2 & 1 & 653 \\
\hline $\mathrm{C} 14$ & -- & 0 & -- & -- & 12 & 12 & $100 \%$ & -- \\
\hline AM241 & 158 & 0 & -- & 701 & 317 & 0 & -- & 842 \\
\hline AM243 & 103 & 6 & $6 \%$ & 108 & 23 & 4 & $17 \%$ & 42 \\
\hline U235 & -- & 0 & -- & -- & -- & 0 & -- & -- \\
\hline ICM & 25 & 0 & -- & & 67 & 0 & -- & 208 \\
\hline IPU & 1730 & 2 & $0.1 \%$ & 1742 & 1423 & 0 & -- & 1669 \\
\hline IPUL & -- & 0 & -- & -- & -- & 0 & -- & -- \\
\hline IPA & 596 & 0 & -- & N/A & 1232 & 0 & -- & N/A \\
\hline IPS & 925 & 0 & -- & N/A & 996 & 0 & -- & N/A \\
\hline IPSA & 323 & 23 & $7 \%$ & $\mathrm{~N} / \mathrm{A}$ & 239 & 17 & $7 \%$ & N/A \\
\hline IPSR & -- & 0 & -- & -- & -- & 0 & -- & -- \\
\hline ISPEC & -- & 0 & -- & -- & 2 & 0 & -- & -- \\
\hline ITPAC & 271 & 0 & -- & N/A & 180 & 0 & -- & N/A \\
\hline ITH & 21 & 0 & -- & 48 & 15 & 0 & -- & 36 \\
\hline IUPU & 127 & 0 & -- & N/A & 178 & 0 & -- & $\mathrm{N} / \mathrm{A}$ \\
\hline IPIU & 38 & 0 & -- & N/A & 26 & 0 & -- & N/A \\
\hline IU & 726 & 10 & $1 \%$ & 465 & 410 & 12 & $3 \%$ & 267 \\
\hline NP237 & 13 & 0 & -- & 24 & 7 & 0 & -- & 15 \\
\hline U236 & 9 & 0 & -- & 17 & 9 & 0 & -- & 24 \\
\hline U238 & & & & & & & & \\
\hline mass & 1314 & 17 & $1 \%$ & 709 & 1792 & 29 & $2 \%$ & 28 \\
\hline LEPD & -- & 0 & -- & -- & -- & 0 & -- & -- \\
\hline PU241 & -- & 0 & -- & -- & -- & 0 & -- & -- \\
\hline Total & 8070 & 58 & $1 \%$ & 5084 & 7455 & 76 & $1 \%$ & 3932 \\
\hline
\end{tabular}

\begin{tabular}{|c|c|c|c|c|c|c|c|c|}
\hline \multicolumn{9}{|l|}{$\mathrm{Fecal}^{(\mathrm{c})}$} \\
\hline ICM & -- & 0 & -- & -- & 4 & 0 & -- & 6 \\
\hline AM241 & 2 & 0 & -- & 88 & 2 & 0 & -- & 133 \\
\hline IPU & 1 & 0 & -- & 88 & 1 & 0 & -- & 126 \\
\hline IPA & 57 & 10 & $18 \%$ & N/A & 89 & 10 & $11 \%$ & N/A \\
\hline Total & 60 & 10 & $17 \%$ & 176 & 96 & 10 & $10 \%$ & 265 \\
\hline
\end{tabular}

${ }^{(a)}$ Procedures not specifically tested are evaluated with isotopic results from other procedures.

(b) $\mathrm{N} / \mathrm{A}=$ not available. QC samples are tracked as isotopic analyses not as multiple analyses.

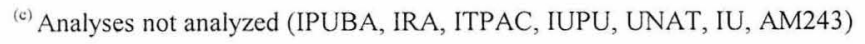


Table 2 presents a breakdown of the numbers and categories for all bioassay samples analyzed, including personnel and QC samples. From 76 urine and 10 fecal QC samples submitted by IDP to GEL during the reporting period, GEL reported 7455 analytical urine results for 18 different analytes and 96 fecal results for 5 different analytes. The 86 QC samples represent $1.1 \%$ of the total analyses performed by GEL. In addition to these samples, GEL analyzed 4764 internal QC samples. The QC samples analyzed equaled 31\% of the samples analyzed by GEL under their contract with Battelle.

GEL's performance was checked by determining detection level, bias, and precision based on the results of blank and spiked samples. Spiked samples fell into two categories: those spiked near the CL, and those spiked at equal to or greater than three times the CL. These two categories were necessary to check compliance with the criteria for relative precision $\left(\mathrm{S}_{\mathrm{B}}\right)$ specified by the Statement of Work. Satisfying these two categories also verified that GEL could detect sample activities near the CL.

\section{DETECTION LEVELS}

Various mathematical expressions and terminology can be used to describe a detection level. The statistical approach specified in the Statement of Work basically follows that of Currie (1968) and HPS N13.30 (HPS 1996). However, the HPS N13.30 formulas were modified to account for the difference between a priori estimates of detection levels based on counts (Currie 1968) and a posteriori estimates based on total activity, where chemical yield is determined specifically for each sample.

Two test criteria were used: the decision level $\left(\mathrm{L}_{\mathrm{c}}\right)$ and the MDA (also called the detection level). The decision level was defined in the Statement of Work as the quantity of radioactivity or mass above which there is at least $95 \%$ confidence that the sample is not a blank (Type I error). If the measured value was greater than the $L_{c}$, the sample was considered likely to contain the radionuclide of interest. If the measured value was less than $\mathrm{L}_{c}$, then the result was considered indistinguishable from a blank. The $\mathrm{L}_{\mathrm{c}}$ was determined solely by measuring blank samples. Before the $L_{c}$ was calculated, results that were significant outliers were eliminated from the data set. Outliers were identified by the use of the criteria of ASTM E178-94 (ASTM 1994). Mathematically, $\mathrm{L}_{\mathrm{c}}$ is defined by the following equation:

$$
L_{c}=2 s_{A}
$$

where, $\mathrm{s}_{\mathrm{A}}$ equals the combined standard uncertainty of the net analyte reported.

The MDA was based on a $95 \%$ probability of detecting activity when the actual activity is equal to the MDA, and conversely a 5\% probability of the results falling below the $\mathrm{L}_{\mathrm{c}}$ and being judged to contain no activity (Type II error). The MDA, expressed in units of disintegrations per minute, is calculated from the same set of blanks as the $\mathrm{L}_{\mathrm{c}}$ (outliers excluded), using the following equation:

$$
\mathrm{MDA}=\overline{\mathrm{X}_{0}}+2\left(\mathrm{t}_{\mathrm{n}-1}\right)_{\mathrm{s}_{0}}+\frac{\left(\mathrm{t}_{\mathrm{n}-1}\right)^{2}}{\mathrm{ERT}}
$$

Where 
$\overline{\mathrm{X}_{\mathrm{o}}}=$ mean net result for the replicate blank samples, in disintegrations per minute

$\mathrm{n}=$ number of replicate blank measurements

$\left(t_{n-1}\right)=$ the $95^{\text {th }}$ quantile of the "student- $t$ " distribution with (n-1) degrees of freedom

$\mathrm{S}_{\mathrm{o}}=$ standard deviation of the net blank, in units of disintegrations per minute

$\mathrm{E}=$ the typical counter detection efficiency in counts per disintegration

$\mathrm{R}=$ the average fractional chemical recovery or yield

$\mathrm{T}=$ the typical counting time.

The above equation is considered appropriate for use with replicate blank results and for comparison with the equation in the contract statement of work, which is calculated with mean count data. In keeping with the philosophy of HPS N13.30, if $\mathrm{t}^{2}$ is less than 3 , then 3 is used instead. For uranium mass analyses, the analytical method does not produce count data; the unit for the analysis result and MDA is micrograms. Thus, the "3" term is not an appropriate part of the equation for the uranium mass analysis.

The present contract with GEL, implemented on April 1, 2005 with GEL, specifies an operational year that ends March $31^{\text {st }}$, each year. This QC report covers the fourth operational year of that contract, and includes samples analyzed by GEL during period of April 1, 2008 through March 31, 2009.

The MDA values GEL calculates for their QC reports are based on mean values for parameters of equation 2 of the contract statement of work, and not replicate measurements. GEL also uses synthetic samples, whereas IDP uses real fecal and urine samples.

The IDP QC samples were evaluated by first calculating the $\mathrm{L}_{\mathrm{c}}$ from blank samples, excluding outliers. This $\mathrm{L}_{c}$ was compared with the $\mathrm{L}_{\mathrm{c}}$ calculated from GEL's own QC samples. Then, the MDA was calculated and compared with the CL and the MDA calculated from GEL's own QC samples. Values used for $\mathrm{E}, \mathrm{R}$, and $\mathrm{T}$ in the MDA equation were obtained from the laboratory, they are listed in Table 3. Finally, the percentage of QC samples spiked at the CL that were measured by the laboratory as having less than the decision level (i.e., no activity was detected) was determined; this percentage was then compared with the $5 \%$ allowed in the Statement of Work. Outliers were included in this test. 
TABLE 3. Typical Chemical Yield (R), Typical Detector Efficiencies (E), and Counting Time (T) Values from GEL Quality Control Report

\begin{tabular}{|c|c|c|c|c|c|c|c|}
\hline \multirow[b]{2}{*}{ Matrix } & \multirow{2}{*}{$\begin{array}{l}\text { Nuclide/ } \\
\text { Method }\end{array}$} & \multirow{2}{*}{$\begin{array}{c}\text { Count } \\
\text { Minutes }\end{array}$} & \multirow{2}{*}{$\begin{array}{l}\text { Contract } \\
\text { Limit }^{(a)}\end{array}$} & \multicolumn{2}{|c|}{ Counter Efficiency } & \multicolumn{2}{|c|}{ Chemical Yield } \\
\hline & & & & $\underline{2009-2010}$ & $\underline{2010-2011}$ & 2009-2010 & $2010-2011$ \\
\hline \multirow[t]{12}{*}{ Urine } & ${ }^{3} \mathrm{H}$ & 20 & 20 & 0.243 & 0.243 & N/A & N/A \\
\hline & Total Sr & 45 & 10 & 0.379 & 0.379 & 0.778 & 0.707 \\
\hline & SR90 & 45 & 10 & 0.379 & 0.379 & 0.759 & 0.707 \\
\hline & ${ }^{241} \mathrm{Am}$ & 2520 & 0.02 & 0.391 & 0.391 & 0.867 & 0.869 \\
\hline & ${ }^{243} \mathrm{Am}$ & 2520 & 0.02 & 0.391 & 0.391 & 0.922 & 0.867 \\
\hline & ${ }^{242} \mathrm{Cm} /{ }^{244} \mathrm{Cm}$ & 2520 & 0.02 & 0.391 & 0.391 & 0.867 & 0.869 \\
\hline & ${ }^{237} \mathrm{~Np}$ & 2520 & 0.02 & 0.391 & 0.391 & 0.717 & 0.648 \\
\hline & ${ }^{239} \mathrm{Pu} /{ }^{238} \mathrm{Pu}$ & 2520 & 0.02 & 0.391 & 0.391 & 0.902 & 0.74 \\
\hline & IPUL & 10000 & 0.005 & --- & --- & --- & --- \\
\hline & ${ }^{228} \mathrm{Th} /{ }^{230} \mathrm{Th} /{ }^{232} \mathrm{Th}$ & 2520 & 0.1 & 0.386 & 0.386 & 0.900 & 0.765 \\
\hline & ${ }^{234} \mathrm{U} /{ }^{235} \mathrm{U} /{ }^{238} \mathrm{U}$ & 2520 & 0.02 & 0.386 & 0.386 & 0.862 & 0.87 \\
\hline & ${ }^{238} \mathrm{U}$ mass & -- & 0.06 & N/A & N/A & N/A & $\mathrm{N} / \mathrm{A}$ \\
\hline \multirow[t]{2}{*}{ Fecal } & ${ }^{241} \mathrm{Am}$ & 960 & 0.8 & 0.391 & 0.391 & 8.865 & 0.864 \\
\hline & ${ }^{238} \mathrm{Pu} /{ }^{239} \mathrm{Pu}$ & 960 & 0.2 & 0.391 & 0.391 & 0.801 & 0.827 \\
\hline
\end{tabular}

(a) Units dpm/sample except $\mathrm{dpm} / \mathrm{mL}$ for ${ }^{3} \mathrm{H}$, and $\mu \mathrm{g} /$ sample for $\mathrm{U}$.

(b) Only one sample analyzed

(c) $\mathrm{NA}=$ Not available. No samples completed.

\section{BIAS}

Relative bias is defined as the mean fractional deviation of the reported results from the true values of spikes added to the samples. The formulas in the Statement of Work used to measure bias in sample results are the same as those in HPS N13.30 (1996). The mean relative bias, $\mathrm{Br}$, is determined using:

$$
B_{r}=\sum_{i=1}^{m} \sum_{j=1}^{n} \frac{B_{r i j}}{N}
$$

where $\mathrm{n}=$ number of spike samples in each level

$\mathrm{m}=$ number of spike levels

$\mathrm{N}=$ total number of spiked samples

$\mathrm{B}_{\mathrm{rij}}=$ bias of a single measurement, defined as:

$$
B_{r i j}=\frac{\left(A_{i j}-A_{a i}\right)}{A_{a i}}
$$

where $\quad A_{i j}=$ the $j$ th measured value of the ith spike level, $A_{a i}=$ the true value of the ith spike level

Outliers were excluded from the test, but not ignored for the procedure evaluation. As stipulated in the Statement of Work, the mean relative bias shall fall within $\pm 20 \%$ when calculated from 15 to 50 spiked samples, and within $\pm 10 \%$ when calculated from over 50 samples. 


\section{PRECISION}

The precision statistic used for this contract was $S_{B}$ from HPS N13.30 (1996), but the limits differ from that standard. $S_{B}$ is given by: where the symbols are the same as for relative bias $\left(\mathrm{B}_{\mathrm{r}}\right)$.

The above equation is valid for samples spiked at one or more levels, subject to the limits

$$
S_{B}=\sqrt{\sum_{i=1}^{m} \sum_{j=1}^{n} \frac{\left(B_{r i j}-B_{r}\right)^{2}}{(N-1)}}
$$

for the relative precision, which depend on the activity of the spikes relative to the CL. Specifically, the relative precision statistics shall be less than or equal to 0.4 for samples spiked greater than three times the $\mathrm{CL}$ and less than or equal to 0.5 for samples spiked between one and three times the CL. Outliers were not included in the determination of precision.

\section{FINDINGS}

Results from three types of QC samples were available: 1) those prepared by GEL and analyzed as single-blinds (spike amount unknown to the analyst), 2) those submitted by IDP and analyzed as single-blinds (spike amount unknown to the analyst), and 3) those submitted by IDP and analyzed as double-blinds (spike amount and sample origin unknown to the analyst).

Single-blind samples this year included 22 urines and 7 artificial fecal samples prepared by RPG. The results of the statistical tests (see Table 4 and Appendix A) are discussed below. Statistical results from the present and previous years are compared in Table 5.

\section{OUTLIERS}

Analytical results that are biased by "blunders" during the analysis should not be included in the data set used for the statistical evaluation of the analytical procedure, but too many outliers would indicate poor laboratory performance (see Table 6). GEL (see Appendix B) identified some outliers associated with their laboratory control samples (blanks and spiked). In future QC reports GEL has been asked not to classify QC data points as outliers and remove them from the database if the result was a statistical anomaly. However, if there was a laboratory error resulting in an erroneous result, then the associated data can be excluded from the performance statistics. Any outliers removed from the data tables need to be addressed in the observation section. 
TABLE 4. Summary of Statistical Values by Nuclide

\begin{tabular}{|c|c|c|c|c|c|c|c|c|c|c|c|}
\hline \multirow[b]{2}{*}{ Isotope $^{(\mathrm{a})}$} & \multirow{2}{*}{$\begin{array}{l}\text { Sample } \\
\text { Source }\end{array}$} & \multicolumn{3}{|c|}{ Blank (dpm) } & \multirow[b]{2}{*}{ CL } & \multicolumn{3}{|c|}{ Spike level at CL (dpm) } & \multicolumn{3}{|c|}{ Spike Level > 2CL (dpm) } \\
\hline & & $\underline{\mathrm{n}}$ & $\underline{\mathrm{L}}_{\mathrm{c}}$ & MDA & & $\underline{n}$ & $\underline{\mathrm{B}_{\mathrm{r}}}$ & $\underline{S}_{B}$ & $\underline{\mathrm{n}}$ & $\underline{B}_{r}$ & $\underline{\mathrm{S}_{B}}$ \\
\hline \multirow[t]{2}{*}{${ }^{3} \mathrm{H}(\mathrm{dpm} / \mathrm{mL})$} & IDP & 0 & $\ldots$ & $\ldots$ & 20 & 0 & . & ... & 0 & & -2 \\
\hline & GEL & 74 & 0.5050 & 0.808 & 20 & 74 & -0.01 & 0.08 & 0 & ... & $\ldots$ \\
\hline${ }^{14} \mathrm{C}(\mathrm{dpm} / \mathrm{ml})$ & IDP & 5 & 0.304 & 0.800 & 10 & 0 & & & 7 & -0.091 & 0.063 \\
\hline \multirow[t]{2}{*}{ Total $\mathrm{Sr} r^{90} \mathrm{Sr}$} & IDP & 3 & 1.707 & 4.119 & 10 & 16 & -0.053 & 0.09 & 0 & & \\
\hline & GEL & 218 & 0.73 & 4.65 & 10 & 217 & $0.12(\mathrm{e})$ & 0.18 & 218 & 0.03 & 0.09 \\
\hline${ }^{237} \mathrm{~Np}$ & GEL & 5 & 0.00 & 0.00 & 10 & 5 & 0.19 & 0.30 & 5 & 0.018 & 0.092 \\
\hline${ }^{228} \mathrm{Th}$ & GEL & 12 & 0.054 & 0.071 & 0.1 & 0 & $\ldots$ & $\ldots$ & 0 & $\ldots$ & $\ldots$ \\
\hline${ }^{229} \mathrm{Th}$ & GEL & 12 & 0.026 & 0.038 & 0.1 & 0 & $\ldots$ & $\ldots$ & 0 & $\ldots$ & $\ldots$ \\
\hline${ }^{232} \mathrm{Th}$ & GEL & 12 & 0.020 & 0.031 & 0.1 & 12 & -0.03 & 0.31 & 12 & -0.006 & 0.07 \\
\hline${ }^{230} \mathrm{Th}$ & GEL & 12 & 0.035 & 0.051 & 0.1 & 0 & $\ldots$ & $\ldots$ & 0 & $\ldots$ & $\ldots$ \\
\hline${ }^{242} \mathrm{Cm}$ & GEL & 71 & 0.004 & 0.009 & 0.02 & 0 & $\ldots$ & $\ldots$ & 0 & $\ldots$ & $\ldots$ \\
\hline${ }^{243,244} \mathrm{Cm}$ & GEL & 71 & 0.004 & 0.010 & 0.02 & 69 & 0.14 (c) & 0.27 & 68 & -0.095 & 0.019 \\
\hline \multirow[t]{2}{*}{${ }^{238} \mathrm{Pu}$-urine } & IDP & 17 & 0.003 & 0.011 & 0.02 & 0 & & & 0 & & \\
\hline & GEL & 557 & 0.005 & 0.013 & 0.02 & 0 & .. & & 0 & & $\ldots$ \\
\hline \multirow[t]{2}{*}{ feces } & IDP & 5 & 0.011 & 0.037 & 0.2 & 0 & & & 5 & -0.079 & 0.080 \\
\hline & GEL & 42 & 0.02 & 0.060 & 0.2 & 0 & $\ldots$ & $\ldots$ & 0 & $\ldots$ & $\ldots$ \\
\hline \multirow[t]{2}{*}{${ }^{239,240} \mathrm{Pu}$-urine } & IDP & 3 & 0.006 & $0.023(\mathrm{e})$ & 0.02 & 14 & 0.046 & 0.294 & 0 & & \\
\hline & GEL & 557 & 0.008 & 0.017 & 0.02 & 555 & 0.04 & 0.30 & 557 & 0.01 & 0.06 \\
\hline \multirow[t]{2}{*}{ feces } & IDP & 5 & 0.011 & 0.036 & 0.2 & 0 & ... & $\ldots$ & 5 & -0.155 & 0.177 \\
\hline & GEL & 42 & 0.04 & 0.096 & 0.2 & 42 & -0.01 & 0.21 & 42 & 0.004 & 0.064 \\
\hline \multirow[t]{2}{*}{${ }^{241}$ Am-urine } & IDP & 3 & 0.008 & $0.025(\mathrm{e})$ & 0.02 & 14 & 0.00 & 0.18 & & & \\
\hline & GEL & 281 & 0.009 & 0.018 & 0.02 & 280 & 0.015 & 0.29 & 281 & -0.086 & 0.081 \\
\hline \multirow[t]{2}{*}{ feces } & IDP & 5 & 0.032 & 0.079 & 0.2 & 0 & .. & & 5 & -0.123 & 0.111 \\
\hline & GEL & 43 & 0.04 & 0.105 & 0.2 & 43 & 0.04 & 0.21 & 42 & -0.048 & 0.073 \\
\hline \multirow[t]{2}{*}{${ }^{243}$ Am-urine } & IDP & 4 & 0.006 & 0.019 & 0.02 & 0 & & 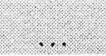 & 0 & $x$ & $\ldots$ \\
\hline & GEL & 14 & 0.011 & 0.021 & 0.02 & 14 & 0.09 & 0.57 & 14 & 0.01 & 0.10 \\
\hline \multirow[t]{2}{*}{${ }^{233,234} \mathrm{U}$} & IDP & 0 & & & 0.02 & 0 & & & 0 & & \\
\hline & GEL & 89 & 0.018 & 0.031 & 0.02 & 0 & $\ldots$ & $\ldots$ & 0 & $\ldots$ & $\ldots$ \\
\hline \multirow[t]{2}{*}{${ }^{235,236} \mathrm{U}$} & IDP & 12 & 0.00 & 0.011 & 0.02 & 0 & & $\ldots$. & 0 & & \\
\hline & GEL & 89 & 0.009 & 0.018 & 0.02 & 0 & $\ldots$ & $\ldots$ & 0 & $\ldots$ & $\ldots$ \\
\hline \multirow[t]{2}{*}{${ }^{238} \mathrm{U}$} & IDP & 0 & & $\ldots$ & 0.02 & 0 & $\ldots$ & $\ldots$ & 12 & 0.043 & 0.108 \\
\hline & GEL & 89 & 0.017 & 0.030 & 0.02 & 89 & 0.06 & 0.33 & 89 & 0.03 & 0.11 \\
\hline \multirow[t]{2}{*}{${ }^{236} \mathrm{U}(\mathrm{ICPMS})^{(\mathrm{b})}$} & IDP & 0 & 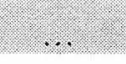 & 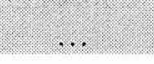 & $140 \mathrm{pg}$ & 0 & & 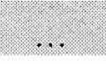 & 0 & & \\
\hline & GEL & 8 & 1.258 & 36.408 & $140 \mathrm{pg}$ & 8 & -0.11 & 0.34 & 8 & -0.03 & 0.05 \\
\hline \multirow[t]{2}{*}{${ }^{238} \mathrm{U}$ (ICPMS) ${ }^{(\mathrm{b})}$} & IDP & 2 & 0.005 & 0.051 & $0.06 \mu g$ & 0 & & $\ldots$ & 27 & -0.05 & 0.24 \\
\hline & GEL & 150 & 0.006 & 0.02 & $0.06 \mu \mathrm{g}$ & 150 & 0.09 & 0.18 & 150 & -0.009 & 0.064 \\
\hline \multicolumn{6}{|c|}{$\begin{array}{l}\text { (b) Units for performance indicators are the same as the units for CL. } \\
\text { (c) Failed performance criterion. }\end{array}$} & \multicolumn{6}{|c|}{$\begin{array}{l}\text { (e) Within statistical uncertainty } \\
\text { (f) Stats for Cm same as Am-241 }\end{array}$} \\
\hline
\end{tabular}


TABLE 5. Comparison of Quality Control Statistics Between the Third and Fourth Contract Year with GEL Using QC Samples Submitted by IDP

\begin{tabular}{|c|c|c|c|c|c|c|c|c|c|c|c|}
\hline \multirow[b]{2}{*}{ Nuclide } & \multirow[b]{2}{*}{$\mathrm{CL}$} & \multicolumn{2}{|c|}{ Report } & \multicolumn{2}{|c|}{ Blanks } & \multicolumn{3}{|c|}{ Spike Level at CL } & \multicolumn{3}{|c|}{ Spike Level at $>3 \mathrm{CL}$} \\
\hline & & Year & $\mathrm{n}$ & $\mathrm{L}_{\mathrm{c}}$ & MDA & $\mathrm{n}$ & $\mathrm{B}_{\mathrm{r}}$ & $\mathrm{S}_{\mathrm{B}}$ & $\mathrm{n}$ & $\mathrm{B}_{\mathrm{r}}$ & $\mathrm{S}_{\mathrm{B}}$ \\
\hline \multirow[t]{2}{*}{${ }^{3} \mathrm{H}$} & \multirow[t]{2}{*}{$20 \mathrm{dpm} / \mathrm{mL}$} & 2010 & 0 & \multirow[t]{2}{*}{$\cdots$} & \multirow{2}{*}{$\cdots$} & 0 & \multirow[t]{2}{*}{$\cdots$} & \multirow[t]{2}{*}{$\cdots$} & 0 & \multirow{2}{*}{$\ldots$} & \multirow{2}{*}{$\begin{array}{l}\ldots \\
\ldots\end{array}$} \\
\hline & & 2009 & 0 & & & 0 & & & 0 & & \\
\hline \multirow[t]{2}{*}{$\mathrm{Sr}$} & \multirow[t]{2}{*}{$10 \mathrm{dpm}$} & 2010 & 3 & \multirow{2}{*}{1.7} & \multirow[t]{2}{*}{4.1} & 16 & -0.05 & 0.09 & 0 & \multirow{2}{*}{$\begin{array}{l}\ldots \\
\ldots\end{array}$} & \multirow{2}{*}{$\begin{array}{l}\ldots \\
\ldots\end{array}$} \\
\hline & & 2009 & 0 & & & 23 & -0.05 & 0.12 & 0 & & \\
\hline \multirow{2}{*}{$\begin{array}{c}\mathrm{U} \\
(\mathrm{ICPMS})\end{array}$} & \multirow[t]{2}{*}{$0.06 \mathrm{mg}$} & 2010 & 2 & \multirow[t]{2}{*}{0.01} & \multirow[t]{2}{*}{0.05} & 0 & \multirow{2}{*}{$\begin{array}{l}\ldots \\
\ldots\end{array}$} & \multirow{2}{*}{$\begin{array}{l}\ldots \\
\ldots\end{array}$} & 27 & -0.05 & 0.24 \\
\hline & & 2009 & 0 & & & 0 & & & 17 & -0.02 & 0.32 \\
\hline \multirow[t]{2}{*}{${ }^{235} \mathrm{U}$} & \multirow[t]{2}{*}{$0.02 \mathrm{dpm}$} & 2010 & 12 & 0.003 & 0.011 & 0 & \multirow{2}{*}{$\begin{array}{l}\ldots \\
\ldots\end{array}$} & \multirow{2}{*}{$\begin{array}{l}\ldots \\
\ldots\end{array}$} & 0 & $\cdots$ & $\ldots$ \\
\hline & & 2009 & 10 & 0.004 & 0.012 & 0 & & & 0 & & $\ldots$ \\
\hline${ }^{238} \mathrm{U}$ & $0.02 \mathrm{dpm}$ & 2010 & 0 & $\ldots$ & $\ldots$ & 0 & $\ldots$ & $\ldots$ & 12 & 0.04 & 0.11 \\
\hline & & 2009 & 0 & $\ldots$ & $\ldots$ & 10 & 0.02 & 0.09 & 0 & $\ldots$ & $\ldots$ \\
\hline${ }^{238} \mathrm{Pu}$ & $0.02 \mathrm{dpm}$ & 2010 & 17 & 0.00 & 0.01 & 0 & $\ldots$ & $\ldots$ & 0 & $\ldots$ & $\ldots$ \\
\hline (urine) & & 2009 & 25 & 0.00 & 0.01 & 0 & $\ldots$ & $\ldots$ & 0 & $\ldots$ & $\ldots$ \\
\hline${ }^{238} \mathrm{Pu}$ & $0.2 \mathrm{dpm}$ & 2010 & 5 & 0.01 & 0.04 & 0 & $\ldots$ & $\ldots$ & 5 & -0.08 & 0.08 \\
\hline (fecal) & & 2009 & 5 & 0.01 & 0.04 & 5 & 0.08 & 0.19 & 0 & $\ldots$ & $\ldots$ \\
\hline & & & & & & & & & & & \\
\hline${ }^{239} \mathrm{Pu}$ & $0.02 \mathrm{dpm}$ & 2010 & 3 & 0.006 & $0.023(\mathrm{e})$ & 14 & 0.05 & 0.29 & 0 & $\cdots$ & $\cdots$ \\
\hline (urine) & & 2009 & 5 & 0.011 & 0.036 & 5 & 0.08 & 0.19 & 0 & $\ldots$ & $\ldots$ \\
\hline${ }^{239} \mathrm{Pu}$ & $0.2 \mathrm{dpm}$ & 2010 & 5 & 0.01 & 0.04 & 0 & $\ldots$ & $\cdots$ & 5 & -0.16 & 0.18 \\
\hline (fecal) & & 2009 & 5 & 0.01 & 0.04 & 5 & -0.02 & 0.13 & 0 & $\ldots$ & $\ldots$ \\
\hline${ }^{241} \mathrm{Am}$ & $0.02 \mathrm{dpm}$ & 2010 & 3 & 0.008 & $0.025(\mathrm{e})$ & 14 & 0.00 & 0.18 & 0 & 0.00 & 0.00 \\
\hline (urine) & & 2009 & 0 & $\ldots$ & $\ldots$ & 18 & -0.06 & 0.21 & 5 & 0.104 & 0.209 \\
\hline${ }^{24 !} \mathrm{Am}$ & $0.2 \mathrm{dpm}$ & 2010 & 5 & 0.03 & 0.08 & 0 & $\ldots$ & $\ldots$ & 5 & -0.12 & 0.11 \\
\hline (fecal) & & 2009 & 0 & $\ldots$ & $\ldots$ & 6.0 & -0.03 & 0.06 & 0 & $\ldots$ & $\ldots$ \\
\hline${ }^{243} \mathrm{Am}$ & $0.02 \mathrm{dpm}$ & 2010 & 4 & 0.006 & 0.019 & 0 & $\ldots$ & $\ldots$ & 0 & $\ldots$ & $\ldots$ \\
\hline & & 2009 & 6 & 0.004 & 0.013 & 0 & $\ldots$ & $\cdots$ & 0 & $\cdots$ & $\ldots$ \\
\hline
\end{tabular}

Vote: $L_{c}$ and MDA units same as $C L . B_{r}$ and $S_{B}$ are unitless (fractional values). 
TABLE 6. Other Indicators of Analytical Uncertainty (IDP Samples)

\begin{tabular}{|c|c|c|c|c|c|c|c|c|}
\hline \multirow[b]{3}{*}{ Nuclide } & \multirow{2}{*}{\multicolumn{2}{|c|}{ IDP QC Samples }} & \multicolumn{4}{|c|}{ Performance Evaluation Samples } & \multicolumn{2}{|c|}{$\begin{array}{c}\text { Analytical Samples } \\
2010-2011\end{array}$} \\
\hline & & & \multicolumn{2}{|c|}{$\begin{array}{l}\text { Spikes at } \\
\text { CDL }\end{array}$} & \multicolumn{2}{|c|}{$\begin{array}{c}\text { False } \\
\text { Negatives }(\%)\end{array}$} & Yield & Failed \\
\hline & Analyses & Outliers & IDP & GEL & IDP & GEL & Flags & Analyses \\
\hline \multicolumn{9}{|l|}{ Urine } \\
\hline${ }^{3} \mathrm{H}$ & 0 & $0(0)$ & 0 & 74 & & $0(0)$ & & \\
\hline $\mathrm{Sr}$ & 19 & $0(0)$ & 16 & 217 & $0(0)$ & $0(0)$ & $5 \%$ & $1 \%$ \\
\hline${ }^{235} \mathrm{U}$ & 12 & $0(0)$ & 0 & 0 & & & $5 \%$ & $4 \%$ \\
\hline${ }^{238} U^{(a)}$ & 12 & $0(0)$ & 12 & 89 & $0(0)$ & $2(2 \%)$ & & \\
\hline${ }^{238} \mathrm{Pu}$ & 17 & $0(0)$ & 0 & 0 & & & $7 \%$ & $1 \%$ \\
\hline${ }^{239} \mathrm{Pu}$ & 17 & $0(0)$ & 14 & 555 & $0(0)$ & $2(0.4 \%)$ & $7 \%$ & $1 \%$ \\
\hline${ }^{241} \mathrm{Am}$ & 17 & $0(0)$ & 14 & 280 & $0(0)$ & $3(1 \%)$ & $1 \%$ & $1 \%$ \\
\hline${ }^{243} \mathrm{Am}$ & 4 & $0(0)$ & 0 & 14 & & & & \\
\hline U-ICPMS ${ }^{\text {(a) }}$ & 29 & $0(0)$ & 27 & 37 & $0(0)$ & $0(0)$ & & \\
\hline Total & 127 & & 83 & 1266 & & & & \\
\hline \multicolumn{9}{|l|}{ Feces } \\
\hline${ }^{241} \mathrm{Am}$ & 10 & $0(0)$ & $5^{(a)}$ & 43 & $0(0)$ & $0(0)$ & $2 \%$ & $1 \%$ \\
\hline${ }^{238} \mathrm{Pu}$ & 10 & $0(0)$ & $5^{(a)}$ & 0 & $0(0)$ & $0(0)$ & $7 \%$ & $1 \%$ \\
\hline${ }^{239} \mathrm{Pu}$ & 10 & $0(0)$ & $5^{(\mathrm{a})}$ & 42 & $0(0)$ & $0(0)$ & $7 \%$ & $1 \%$ \\
\hline Total & 30 & & 15 & 85 & & & & \\
\hline
\end{tabular}

(a) sample spiked at $>3 \mathrm{CL}$

\section{TRITIUM}

Effective June 2006, the tritium intercomparison program by IDP was discontinued. Performance indicators will be evaluated through GEL's QC program. The control samples run by GEL also met all the acceptance criteria tested as part of the quality control program. The tritium analyses were considered acceptable.

\section{STRONTIUM-90 AND TOTAL STRONTIUM}

The total strontium procedure is used to screen samples to determine whether analysis for ${ }^{90} \mathrm{Sr}$ is warranted. Samples with total strontium results less than $15 \mathrm{dpm}$ do not undergo further analysis. Samples with results greater than or equal to $15 \mathrm{dpm}$ may undergo ${ }^{90} \mathrm{Y}$ ingrowth to specifically determine ${ }^{90} \mathrm{Sr}$ levels. The calculated MDA, reported by GEL and tested by IDP, for the total strontium part of the analysis was less than $46 \%$ of the CL. The MDA, relative bias and precision, tested by IDP and GEL for the ${ }^{90} \mathrm{Sr}$ and total Sr procedures were all limits. The relative bias was slightly elevated but within statistical uncertainty. The 16 samples spiked at the contractual level by IDP were all detected. The strontium urinalysis procedure was concluded to be acceptable. 


\section{PLUTONIUM-238 AND -239}

Samples spiked with ${ }^{238} \mathrm{Pu}$ and ${ }^{239} \mathrm{Pu}$ were analyzed using the same procedures and same reagents. The two isotopes are differentiated only at the end of the procedure by alpha spectrometry. Therefore, laboratory performance is expected to be similar for both isotopes using any of the seven procedures that incorporate plutonium analysis (IPU, IPA, IPS, IPSA, IPSR, IUPU and ITPAC).

The MDAs and performance statistics for ${ }^{239} \mathrm{Pu}$ and ${ }^{238} \mathrm{Pu}$ in urine were acceptable: The MDA tested by IDP was slightly elevated but only three samples were submitted and the statistical variation was therefore high. The MDA tested by GEL and based on 557 samples was $25 \%$ less than the criteria. The 14 samples spiked at the CL for ${ }^{239} \mathrm{Pu}$ all showed detection and the relative bias and precision met the acceptance criteria. Out of 555 samples spiked by GEL at the CDL, only 2 samples did show detection, giving a false-negative (beta error) of $0.4 \%$, which was acceptable. There were 17 blank samples analyzed for ${ }^{238} \mathrm{Pu}$ activity, none of the 17 samples detected activity in excess of the decision level. Overall the plutonium urinalyses were considered acceptable.

The MDA and performance statistics for ${ }^{239} \mathrm{Pu}$ and ${ }^{238} \mathrm{Pu}$ in feces were likewise acceptable. More than $15 \%$ of the fecal samples analyzed were duplicated to test the consistency of the aliquoting procedure. A review of the duplicate samples determined that the aliquoting procedure produced results with a variation of less than 3-sigma. The fecal aliquoting procedure was acceptable. This year IDP submitted 10 actual fecal samples, five samples were blanks and five samples were spiked with very insoluble ${ }^{239} \mathrm{Pu}$ and slightly soluble ${ }^{238} \mathrm{Pu}$. The MDA, precision and bias for ${ }^{239} \mathrm{Pu}$ and ${ }^{238} \mathrm{Pu}$ met the performance criteria. The performance statistics reported by GEL for ${ }^{239} \mathrm{Pu}$ and ${ }^{238} \mathrm{Pu}$ also met the acceptance criterion. The failed analysis rate for fecal sampling was $1 \%$ with a low or high yield rate of $7 \%$, which is within the contractual level of $10 \%$. Overall the plutonium fecal analyses were considered acceptable but the failed analysis rate will continue to be monitored.

\section{ISOTOPIC URANIUM}

The isotopic uranium analysis reports on three uranium isotopes: ${ }^{234} \mathrm{U},{ }^{235} \mathrm{U}$ and ${ }^{238} \mathrm{U}$. The isotopes are differentiated only during counting by alpha spectrometry. All performance criteria were met within statistical variation. Of the 89 samples that GEL spiked at the CDL, only two samples did show detection, giving a false-negative (beta error) of $2 \%$, which was acceptable.

Because IDP used a depleted uranium source material for the isotopic uranium urinalyses, ${ }^{233,234} \mathrm{U}$ was not evaluated. However, the performance statistics for ${ }^{235} \mathrm{U}$ and ${ }^{238} \mathrm{U}$ were reviewed and the MDA for ${ }^{235} \mathrm{U}$ and the bias and precision for ${ }^{238} \mathrm{U}$ were acceptable.

\section{URANIUM MASS}

No concerns were identified with the ${ }^{238} \mathrm{U}$ mass urinalysis program using inductivelycoupled plasma mass spectrometry (ICPMS) and it was considered acceptable. Because IDP uses a $0.2 \mu \mathrm{g}$ screening level for ${ }^{238} \mathrm{U}$ mass, samples spiked at $0.06 \mu \mathrm{g}$ were discontinued. The MDA at the contractual level of $0.06 \mu \mathrm{g}$ was evaluated through GEL's program and was found to be acceptable. The first quarter GEL recorded ${ }^{238} \mathrm{U}$ mass results as Total Uranium, a convention used when the KPA system was used for total uranium mass analyses. This was in error because the results were not total uranium but ${ }^{238} \mathrm{U}$ mass by ICPMS, the error was identified before the end of the first quarter and the problem was corrected. However, the relative bias and precision were reported separating for the quality control samples labeled as Total Uranium results and ${ }^{238} \mathrm{U}$ mass (ICPMS). The values listed in Table 4 for relative bias and precision are a compilation of the two datasets. The relative bias and precision were likewise acceptable. The bias and 
precision as tested by IDP met the acceptance criteria. The bias and precision were tested by IDP at $0.2 \mu \mathrm{g}$ and by GEL at $1 \mu \mathrm{g} / \mathrm{sample}$ and at $0.05 \mu \mathrm{g} / \mathrm{sample}$.

\section{URANIUM-236 VIA INDUCTIVELY COUPLED PLASMA MASS SPECTROMETRY (ICPMS)}

The performance statistics for the ${ }^{236} \mathrm{U}$ analysis using ICPMS were supplied by GEL's QC program, IDP did not submit QC samples. The MDA and relative bias and precision reported by GEL met the performance criteria. The ${ }^{236} \mathrm{U}$ analysis procedure was considered acceptable.

\section{AMERICIUM-241}

The ${ }^{241} \mathrm{Am}$ fecal and urine analyses met the acceptance criteria for MDA, relative bias and precision. The MDA tested by IDP was slightly elevated but only three samples were submitted and the statistical variation was therefore high. The MDA as reported by GEL was less than $10 \%$ of the contractual level. All 14 of the ${ }^{241} \mathrm{Am}$ samples spiked at the contractual detection level (CDL) were detected. Out of 280 samples spiked by GEL at the CDL, only three samples did show detection, giving a false-negative (beta error) of $1 \%$, which was acceptable. The relative bias and precision as reported by GEL and tested by IDP met the performance criteria. The current AM241 urinalysis procedure was considered acceptable.

The ${ }^{241}$ Am fecal duplicate samples were evaluated and it was concluded that the aliquoting procedure produced results within the control limits. This year IDP submitted five actual fecal samples spiked with very insoluble ${ }^{241} \mathrm{Am}$ and the relative bias and precision were acceptable. Overall the ${ }^{241} \mathrm{Am}$ fecal analyses were considered acceptable.

\section{AMERICIUM-243}

The AM243 procedure was identical to the AM241 procedure, except a different tracer is used $\left({ }^{244} \mathrm{Cm}\right.$ instead of $\left.{ }^{243} \mathrm{Am}\right)$. The seven blank ${ }^{243} \mathrm{Am}$ QC samples submitted were all reported with results less than the decision level and the calculated MDA was $50 \%$ of the contractual detection level. The performance statistics for ${ }^{243} \mathrm{Am}$, as tested by GEL, met the acceptance criteria. The AM243 procedure was concluded to be acceptable.

\section{ISOTOPIC CURIUM}

IDP did not submit QC samples to test the isotopic curium program, therefore performance statistics were based on the GEL QC results. GEL tested the MDA for ${ }^{242} \mathrm{Cm}$ and ${ }^{244} \mathrm{Cm}$ and the relative bias and precision for ${ }^{244} \mathrm{Cm}$. The average relative bias of ${ }^{244} \mathrm{Cm}$ was slightly elevated but it was not considered a concern (see Table 4). Overall the results met the acceptance criteria and the isotopic curium urinalysis program was considered acceptable.

\section{ISOTOPIC THORIUM}

IDP also did not submit QC samples to test the isotopic thorium program, therefore performance statistics were based on the GEL QC results. GEL tested the MDA for ${ }^{228} \mathrm{Th},{ }^{229} \mathrm{Th},{ }^{230} \mathrm{Th}$ and ${ }^{232} \mathrm{Th}$ and the relative bias and precision for ${ }^{232} \mathrm{Th}$. Of the 12 samples spiked with ${ }^{232} \mathrm{Th}$, one sample did not show detection, resulting in a false-negative percent (beta error) of $8 \%$, which was determined to be acceptable, assuming the normal statistical variation in the measurement process. Overall the results met the acceptance criteria and the isotopic thorium urinalysis program was considered acceptable. 


\section{NEPTUNIUM-237}

Neptunium-237 was likewise not tested by IDP and the performance statistics were supplied by the GEL's QC program. The MDA, average relative bias and precision met the performance criteria and the NP237 analysis was considered acceptable.

\section{CARBON-14}

Anticipating that decommissioning and decontamination (D\&D) work in the old production reactors on the Hanford site might begin in the next few years, IDP requested the Department of Energy Laboratory Accreditation Program (DOELAP) certification for routine ${ }^{14} \mathrm{C}$ urinalyses. The current statement of work only specified non-routine ${ }^{14} \mathrm{C}$ bioassays, which was outside the scope of DOELAP. DOELAP Test Session 13, included ${ }^{14} \mathrm{C}$ urine samples for GEL to analyze and report. However, GEL LLC did not meet the acceptance criteria for ${ }^{14} \mathrm{C}$ urinalyses under the guidelines set forth by DOELAP. GEL's analytical results showed biases ranging from -0.51 to -0.65 , the DOELAP acceptable range was 0.25 to 0.5 . As follow-up, IDP submitted 12 samples for analysis to further test the procedure. Five blank samples and 12 spiked samples were submitted and the MDA, average relative bias and precision all met IDP's contractual specifications. GEL requested from DOELAP another set of samples and once again GEL's analytical results showed a negative bias that did not meet the acceptance criteria. A review of the DOELAP prepared samples identified differences in the sample preparation and spike material that would require additional handling than covered in GEL's routine procedures.

Before proposing a re-evaluation of the ${ }^{14} \mathrm{C}$ analysis procedure, IDP reviewed the criteria for a ${ }^{14} \mathrm{C}$ bioassay routine monitoring program. Based on the source material, characterization data and proposed D\&D work, a routine ${ }^{14} \mathrm{C}$ bioassay monitoring program would not be needed. The request for DOELAP certification for ${ }^{14} \mathrm{C}$ urinalyses was withdrawn and additional performance evaluation samples were not requested. Appendix A includes the documentation reviewing the need for a ${ }^{14} \mathrm{C}$ bioassay monitoring program at the Hanford site and email correspondences addressing the DOELAP samples and IDP ${ }^{14} \mathrm{C}$ audit samples.

\section{FOLLOW-UP ON CONCERNS DURING THE FIFTH CONTRACT YEAR}

There were a few concerns carried over from the fourth contract year, primarily technician errors involving sample batches, typically consisting of loss of sample (e.g, dropping, breakage and spillage), cross contamination, forgetting to perform a task, or lack of proper documentation. Over the year there were about 5 separate incidents resulting in 38 failed analyses including plutonium, strontium and isotopic uranium. The failure rate was still well below $10 \%$ for all analytes.

Incident reports issued during the fourth contract year and their follow-up are reported in Appendix B. 


\section{SUMMARY OF THE BIOASSAY QUALITY CONTROL REPORT FROM GEL INCORPORATED, FOR THE CONTRACT 112512 FIRST YEAR 2010/2011 (a)}

GEL reported all analytical batches were analyzed with a reagent blank (Umass only), matrix blank or both. GEL considered blanks in control when the calculated MDA was less than the Contract Limit $(\mathrm{CL})$ and the $\mathrm{L}_{\mathrm{c}}$ was less than $1 / 2 \mathrm{CL}$ (see Appendix B). In addition, the chemical tracer yields were evaluated against the yield requirements stated in the subject contract. Overall, GEL believed that the blank and spike data for each analytical process demonstrated that the analyses were in control.

In the review GEL indentified laboratory control samples that had yields greater than $125 \%$ as well as one excreta sample that had a tracer yield greater than $125 \%$. GEL also indentified laboratory control samples that met the criteria for low yield, but likewise a review of excreta sample results found the low yield rate to be acceptable. The urine sampling program showed acceptable levels for low-yields for all analyses. The isotopic plutonium urinalysis and fecal analysis program showed the highest low yield rate at $7 \%$, which is below the $10 \%$ level for follow-up.

\section{RESULTS FROM INTERCOMPARISON PROGRAMS}

GEL participated in two intercomparison programs (Appendix C - Intercomparison Programs) in the first contract year. Between August and October 2010, GEL participated in the National Institute of Standards and Technology's program testing the relative bias and precision for ${ }^{60} \mathrm{Co},{ }^{137} \mathrm{Cs},{ }^{238} \mathrm{Pu}$, ${ }^{240,239} \mathrm{Pu},{ }^{241} \mathrm{Am},{ }^{230} \mathrm{Th},{ }^{235} \mathrm{U},{ }^{238} \mathrm{U},{ }^{234} \mathrm{U}$ and ${ }^{90} \mathrm{Sr}$ in synthetic feces. GEL met the acceptance criteria for relative bias and precision for all isotopes. GEL also participated in the National Institute of Standards and Technology's program testing the relative bias and precision for ${ }^{241} \mathrm{Am}+{ }^{243} \mathrm{Cm},{ }^{60} \mathrm{Co},{ }^{57} \mathrm{Co},{ }^{137} \mathrm{Cs}$, ${ }^{226} \mathrm{Ra},{ }^{238} \mathrm{Pu},{ }^{240,239} \mathrm{Pu},{ }^{241} \mathrm{Am},{ }^{230} \mathrm{Th},{ }^{235} \mathrm{U},{ }^{238} \mathrm{U},{ }^{234} \mathrm{U}$ and ${ }^{90} \mathrm{Sr}$, in synthetic urine. GEL met the acceptance criteria for relative bias and precision on all isotopes.

In 2010 GEL participated in session 13 of DOELAP and was tested for ${ }^{60} \mathrm{Co},{ }^{137} \mathrm{Cs},{ }^{238} \mathrm{Pu}$, ${ }^{240,239} \mathrm{Pu},{ }^{241} \mathrm{Am},{ }^{230} \mathrm{Th},{ }^{228} \mathrm{Th},{ }^{232} \mathrm{Th},{ }^{237} \mathrm{~Np},{ }^{235} \mathrm{U},{ }^{238} \mathrm{U},{ }^{234} \mathrm{U}$ and ${ }^{90} \mathrm{Sr}$ in synthetic feces. GEL met the acceptance criteria for relative bias and precision for all isotopes in feces. For the urine program, GEL was tested in ${ }^{14} \mathrm{C},{ }^{3} \mathrm{H},{ }^{60} \mathrm{Co},{ }^{137} \mathrm{Cs},{ }^{238} \mathrm{Pu},{ }^{240,239} \mathrm{Pu},{ }^{241} \mathrm{Am},{ }^{230} \mathrm{Th},{ }^{228} \mathrm{Th},{ }^{232} \mathrm{Th},{ }^{237} \mathrm{~Np},{ }^{235} \mathrm{U},{ }^{238} \mathrm{U},{ }^{234} \mathrm{U}$, ${ }^{238} \mathrm{U}$-mass and ${ }^{90} \mathrm{Sr}$ in synthetic urine. GEL passed the performance statistics for relative bias and precision for all isotopes except ${ }^{14} \mathrm{C}$, which was discussed above in the CARBON-14 section.

\section{REFERENCES}

American Society for Testing and Materials (ASTM). 1994. Standard Practice for Dealing with Outlying Observations. ASTM E 178-94, ASTM, Philadelphia, Pennsylvania.

Health Physics Society (HPS). 1996. Health Physics Society Standard for Performance Criteria for Radiobioassay. HPS N13.30-1996, HPS, McLean, VA.

Battelle. 2010. "Contract No. 112512 Bioassay Radiochemical Analytical Services" General Engineering Laboratories, LLC, Charleston, South Carolina. (Available from the Hanford Radiological Records Historical File.)

(a) Summaries are taken from GEL (2010). 
Battelle. 2009. "Contract No. 11530 Mod 11 Bioassay Radiochemical Analytical Services" General Engineering Laboratories, LLC, Charleston, South Carolina. (Available from the Hanford Radiological Records Historical File.)

Currie, L. A. 1968. "Limits for Qualitative Detection and Quantitative Determination." Analytical Chemistry 40(3):586-593.

Pizarro, S. 2009. " PNNL Annual QC Package, Fifth Contract Year 2009/2010 (April 1, 2009 - March 31, 2010)" Letter Report, General Engineering Laboratories, LLC, Charleston, South Carolina. (Available from the Hanford Radiological Records Historical File.)

Pizarro, S. 2010. " PNNL Annual QC Package, First Contract Year 2010/2011 (April 1, 2010 - March 31, 2011)" Letter Report, General Engineering Laboratories, LLC, Charleston, South Carolina. (Available from the Hanford Radiological Records Historical File.)

Remmington, Richard D. and M. Anthony Schork, 1970. Statistics with Applications to the Biological and Health Sciences. Printice-Hall. New York.

Miller, Irwin and John Freund, 1977. Probability and Statistics for Engineers. Prentice-Hall. Englewood Cliffs, New Jersey. 


\section{RELEVANT PROCEDURES AND CORRESPONDENCE}

Antonio, C. L.. 2012. "Results of the PNL Excreta Bioassay Quality Control Oversight Program for April 1, 2010 through June 30, 2011." Letter Report, Pacific Northwest Laboratory, Richland, Washington. (Available from the Hanford Radiological Records Historical File.)

Antonio, C. L. 2012. "Results of the PNL Excreta Bioassay Quality Control Oversight Program for July 1, 2010 through September 30, 2010." Letter Report, Pacific Northwest Laboratory, Richland, Washington. (Available from the Hanford Radiological Records Historical File.)

Antonio, C. L. 2012. "Results of the PNL Excreta Bioassay Quality Control Oversight Program for October 1, 2010 through December 31, 2010." Letter Report, Pacific Northwest Laboratory, Richland, Washington. (Available from the Hanford Radiological Records Historical File.) 
ATTACHMENT 1 - CARBON-14 FOLLOW UP 


\section{Antonio, Cheryl L}

From:

Carbaugh, Eugene $\mathrm{H}$

Sent:

Thursday, April 19, 2012 3:33 PM

To:

Antonio, Cheryl L

Subject:

C-14 reports

Attached are the PNNL report and the ORS journal publication. Simply put, based on the conclusions of these reports and the available data for graphite reactor decommissioning, there does not appear to be a likely need for any kind of routine $\mathrm{C}-14$ bioassay. Hence the effort to achieve accreditation in the $\mathrm{C}-14$ category is not being pressed by PNNL.

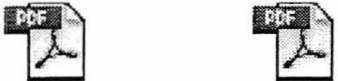

PNNL-SA-75300 Jarbon_14_Bioasse

C-14 Bioassay fu... y_for_Decommi...

\section{Gene}

Eugene H. Carbaugh, CHP

Staff Scientist and Internal Dosimetry Manager

Pacific Northwest National Laboratory

Phone: (509) 376-6632

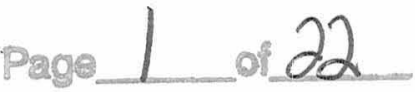


Prepared for the U.S. Department of Energy under Contract DE-AC05-76RL01830

\section{Carbon-14 Bioassay for Decommissioning of Hanford Reactors}

EH Carbaugh
DJ Watson

September 2010

Pacific Northwest

NATIONAL LABORATORY 


\section{DISCLAIMER}

This report was prepared as an account of work sponsored by an agency of the United States Government. Neither the United States Government nor any agency thereof, nor Battelle Memorial Institute, nor any of their employees, makes any warranty, express or implied, or assumes any legal liability or responsibility for the accuracy, completeness, or usefulness of any information, apparatus, product, or process disclosed, or represents that its use would not infringe privately owned rights. Reference herein to any specific commercial product, process, or service by trade name, trademark, manufacturer, or otherwise does not necessarily constitute or imply its endorsement, recommendation, or favoring by the United States Government or any agency thereof, or Battelle Memorial Institute. The views and opinions of authors expressed herein do not necessarily state or reflect those of the United States Government or any agency thereof.

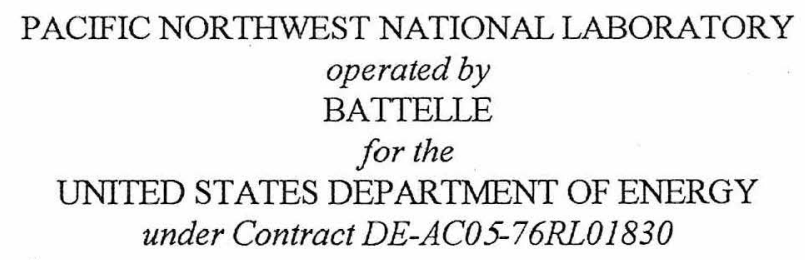

Printed in the United States of America

Available to $D O E$ and $D O E$ contractors from the Office of Scientific and Technical Information, P.O. Box 62, Oak Ridge, TN 37831-0062; ph: (865) 576-8401 fax: (865) 576-5728 email: reports@adonis.osti.gov

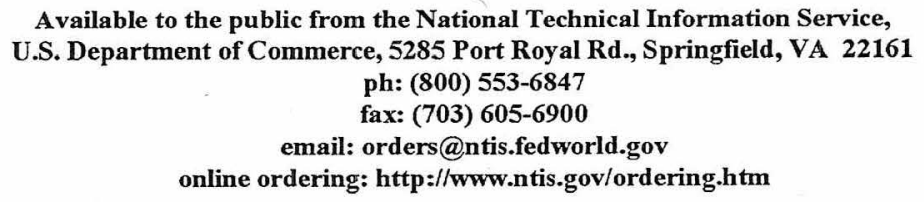

This document was printed on recycled paper. 


\section{Carbon-14 Bioassay for Decommissioning of Hanford Reactors}

EH Carbaugh

DJ Watson

September 2010

Prepared for

the U.S. Department of Energy

under Contract DE-AC05-76RL01830

Pacific Northwest National Laboratory

Richland, Washington 99352

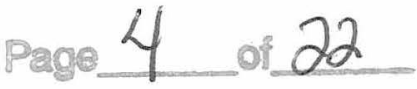




\section{Contents}

Contents

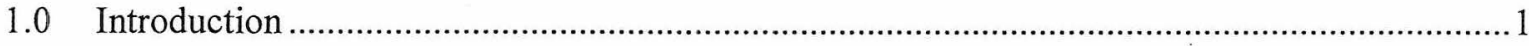

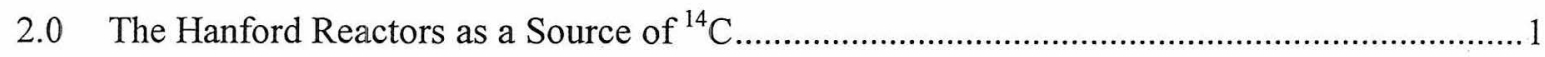

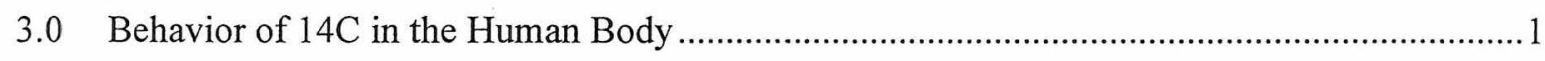

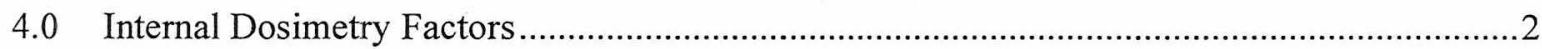

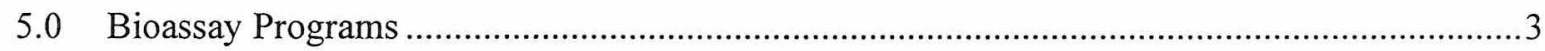

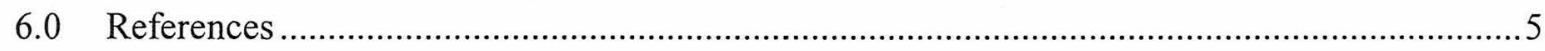

\section{Tables}

Table 1. Effective dose coefficients, annual limits on intake and derived air concentrations for

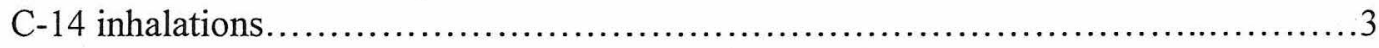

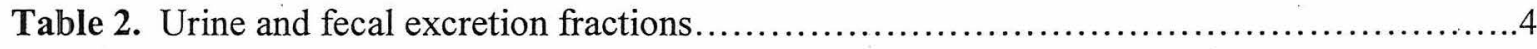

\section{Figures}

Figure 1. Urine and fecal excretion following single acute inhalation intake of ${ }^{14} \mathrm{C} \ldots \ldots \ldots \ldots \ldots 6$ 


\section{CARBON-14 BIOASSAY FOR DECOMMISSIONING OF HANFORD REACTORS}

\subsection{Introduction}

The old production reactors at the US Department of Energy Hanford Site used large graphite blocks as the moderator. The last of these reactors was permanently shut down in 1986, and the long range site plan for their decommissioning has been to cocoon them for 75 years to allow the relatively short half-life radionuclides to decay away. After 75 years the intent was to transport the graphite piles several miles to a below ground disposal facility. Funds being made available under the American Recovery and Reinvestment Act of 2009 may result in some or all of this work occurring much sooner than was originally planned. Questions have been raised about the potential need for 14C bioassay of workers who might be involved in this work, and the technical issues associated with such bioassay.

Carbon-14 decays with a half-life of 5730 years by pure beta decay. The beta particle emitted has a low average energy of $49.45 \mathrm{keV}$. It is formed naturally in the upper atmosphere by cosmic ray interactions with $14 \mathrm{~N}$. The natural abundance of $14 \mathrm{C}$ is approximately one part per trillion $(10-12)$, or about $6 \mathrm{pCi} / \mathrm{gC}(\mathrm{NCRP} 1985)$.

\subsection{The Hanford Reactors as a Source of ${ }^{14} \mathrm{C}$}

Carbon-14 is an unavoidable activation product in nuclear reactors such as the former Hanford production reactors that used graphite moderated cores. Carbon-14 production arises from neutron bombardment through one of two processes: the $14 \mathrm{~N}(\mathrm{n}, \mathrm{p}) 14 \mathrm{C}$ reaction, with a capture cross section of 1.8 barns, and the $13 \mathrm{C}(\mathrm{n}, \gamma) 14 \mathrm{C}$ transmutation, with a capture cross section of 0.0009 barns. Nitrogen impurities found in the graphite, the water coolant and the core cover gas all contribute to $14 \mathrm{C}$ production. Thus, carbon-14 concentrations can fluctuate between reactors due to varying levels of these impurities and reactor operating conditions. The nitrogen source also affects the form of the resulting 14C: nitrogen impurities in graphite lead to $14 \mathrm{C}$ incorporated in the graphite lattice or pore spaces, while coolant or cover gas nitrogen leads to carbonaceous solids or amorphous carbon deposited on the surfaces and open pore spaces of the graphite (EPRI 2006).

Hanford reactors contain between 1400 and 2800 tons of graphite per reactor. Graphite samples in $1958,1967,1976,1977$ and the early 1980 s showed $14 \mathrm{C}$ concentrations ranging from 0.2 to $3.4 \mu \mathrm{Ci} / \mathrm{g}$ (Paasch 1985, Miller and Steffes 1987), with a nominal mean of $2.4 \mu \mathrm{Ci} / \mathrm{g}$. Samples collected included powder from a reactor process core tube broaching tool (likely representing $14 \mathrm{C}$ generated primarily from neutron reactions with the nitrogen cover gas) and core drillings (likely representing $14 \mathrm{C}$ created from nitrogen impurities in the graphite matrix and activation of 13C).

\subsection{Behavior of $14 \mathrm{C}$ in the Human Body}

Reference Man (ICRP 1974) shows the carbon content for an adult male to be $16,000 \mathrm{~g}$ with the equilibrium carbon balance being $300 \mathrm{~g} / \mathrm{d}$ intake in food and fluids, and losses of $270 \mathrm{~g} / \mathrm{d}$ by exhalation, 5 $\mathrm{g} / \mathrm{d}$ by urine (mostly as urea), $7 \mathrm{~g} / \mathrm{d}$ by feces, and for the remaining $18 \mathrm{~g} / \mathrm{d}$ through all other losses (e.g., sweat). Using these parameters, and the environmental abundance of $14 \mathrm{C}$ as 10-12, the Reference Man $14 \mathrm{C}$ body content is about $71 \mathrm{nCi}$. Based on the carbon balance, background excretion of $14 \mathrm{C}$ is estimated at $30 \mathrm{pCi} / \mathrm{d}$ in urine and $42 \mathrm{pCi} / \mathrm{d}$ in feces. Assuming $1600 \mathrm{~mL} / \mathrm{d}$ urine excretion and $150 \mathrm{~g} / \mathrm{d}$ 
fecal excretion of Reference Man (ICRP 2002), the respective concentrations would be about 0.04 $\mathrm{dpm} / \mathrm{mL}$ and $0.6 \mathrm{dpm} / \mathrm{g}$.

Absorption of $14 \mathrm{C}$ in the respiratory tract is highly dependent on its chemical form, as described in ICRP 68 (1994) and ICRP 71 (1995) for gases or vapors and ICRP 71 for particulates. Carbon monoxide (14CO) is considered Vapor Class SR-1, a soluble or reactive gas or vapor, with $40 \%$ of the inhalation instantaneously absorbed to blood and bound to hemoglobin and $60 \%$ exhaled. As carbon dioxide (14CO2) or an organic compound, it is described as Vapor Class SR-2, highly soluble or reactive gas or vapor, with $100 \%$ of the inhalation completely and instantaneously absorbed into blood from the respiratory tract. The biological half-time used for inhaled carbon monoxide absorbed in the body is 200 minutes. Inhaled carbon dioxide is assumed to be uniformly distributed throughout all organs and tissues.

Carbon can exist as all three particulate absorption types, Type F, M, or S. Rat studies cited in ICRP 71 indicated diesel exhaust particles exhibited Type M behavior, whereas 14C-bearing material obtained from air filters during re-tubing of a CANDU reactor were consistent with Type S material. Graphite is a highly insoluble crystalline form of carbon that is considered to demonstrate Type S behavior. Any $14 \mathrm{C}$ formed within the graphite matrix is likewise considered to demonstrate Type S behavior. The f1 absorption fractions for Types F, M, and S are respectively, 1, 0.1 and 0.01. Type F carbon compounds are not specifically identified in the ICRP publications, however are considered to be particulate aerosols of organic compounds.

Once absorbed in the blood, the biokinetic model for metabolized carbon in the body assumes a $100 \%$ distribution uniformly in all organs and tissues from which it clears with a 40-day biological half-time.

\subsection{Internal Dosimetry Factors}

The ICRP has compiled committed effective dose coefficients [e(50)] for $14 \mathrm{C}$ in the dioxide, monoxide, labeled methane, and organic gases and vapors forms in the ICRP CD-1 database (ICRP 2001). In addition, ICRP 71 tabulated effective dose coefficients for inhalation of absorption type $F$, $M$, and $S$ particles, but using a particle size of 1- $\mu \mathrm{m}$ AMAD for public exposures instead of the 5- $\mu \mathrm{m}$ AMAD particle size recommended for occupational exposure. Thus, for this work of occupational monitoring program design, $\mathrm{e}(50)$ values assuming 5- $\mu \mathrm{m}$ AMAD particles were calculated using the IMBA Professional Plus ${ }^{\mathrm{TM}}$ computer code1, assuming the standard biokinetic models and a density of 2.16 $\mathrm{g} / \mathrm{cm} 3$ for graphite particles. Results are shown in Table 1 along with the ICRP values for gases and vapors.

\footnotetext{
${ }^{1}$ IMBA Professional Plus is available from Health Protection Agency (HPA), Radiation Protection Division, Chilton, Didicot, Oxon., OX11 0RQ, UK, and from http://www.imbaprofessional.com/
} 
Table 1. Effective dose coefficients, annual limits on intake and derived air concentrations for C-14 inhalations

\begin{tabular}{lccc}
\hline $\begin{array}{c}\text { Form of Inhalation } \\
\text { Intake }\end{array}$ & $\begin{array}{c}\text { Effective Dose } \\
\text { Coefficient, } \\
\boldsymbol{e}(\mathbf{5 0}) \\
(\mathbf{S v} / \mathbf{B q})\end{array}$ & $\begin{array}{c}\text { Annual Limit on } \\
\text { Intake } \\
(\text { stochastic }) \\
(\boldsymbol{\mu C i})\end{array}$ & $\begin{array}{c}\text { Derived Air } \\
\text { Concentration } \\
(\boldsymbol{\mu C i} / \mathbf{m L})\end{array}$ \\
\hline${ }^{14} \mathrm{C}$ dioxide & $6.50 \mathrm{E}-12^{(\mathrm{a})}$ & $2.1 \mathrm{E}+05^{(\mathrm{a})}$ & $7 \mathrm{E}-04^{(\mathrm{c})}$ \\
${ }^{14} \mathrm{C}$ monoxide & $8.00 \mathrm{E}-13^{(\mathrm{a})}$ & $1.7 \mathrm{E}+06^{(\mathrm{a})}$ & $8 \mathrm{E}-05^{(\mathrm{c})}$ \\
${ }^{14} \mathrm{C}$ labeled methane & $2.90 \mathrm{E}-12^{(\mathrm{a})}$ & $4.7 \mathrm{E}+05^{(\mathrm{a})}$ & $2.0 \mathrm{E}-04^{(\mathrm{a})}$ \\
${ }^{14} \mathrm{C}$ organic gases and & $5.80 \mathrm{E}-12^{(\mathrm{a})}$ & $2.3 \mathrm{E}+03^{(\mathrm{a})}$ & $9 \mathrm{E}-07^{(\mathrm{c})}$ \\
${ }^{\text {vapors }}$ & & & \\
${ }^{14} \mathrm{C}$ Vapor Class SR-2 & $5.81 \mathrm{E}-12^{(\mathrm{b})}$ & $2.3 \mathrm{E}+03^{(\mathrm{b})}$ & $9.6 \mathrm{E}-07^{(\mathrm{b})}$ \\
${ }^{14} \mathrm{C}$ Type F particulate & $2.79 \mathrm{E}-10^{(\mathrm{b})}$ & $4.6 \mathrm{E}+02^{(\mathrm{b})}$ & $1.9 \mathrm{E}-06^{(\mathrm{b})}$ \\
${ }^{14} \mathrm{C}$ Type M particulate & $1.50 \mathrm{E}-09^{(\mathrm{b})}$ & $9.9 \mathrm{E}+02^{(\mathrm{b})}$ & $4.1 \mathrm{E}-07^{(\mathrm{b})}$ \\
${ }^{14} \mathrm{C}$ Type S particulate & $4.05 \mathrm{E}-09^{(\mathrm{b})}$ & $3.5 \mathrm{E}+02^{(\mathrm{b})}$ & $1.5 \mathrm{E}-07^{(\mathrm{b})}$ \\
\hline
\end{tabular}
a.) based on ICRP CD-1 dose coefficients
b.) based on IMBA Professional Plus
c.) from 10 CFR 835 Appendix A (2007)

Table 1 also shows annual limits on intake (ALIs) and derived air concentrations (DACs). Stochastic ALIs were calculated for each of the exposure forms by dividing the United States regulatory limit of 5 rem effective dose by the e(50). DACs were then calculated for the type F, M, and S particulate intakes by dividing the ALI by the volume of air breathed by Reference Man in a year ( $2.4 \mathrm{E}+09 \mathrm{~mL})$. Units were converted to the conventional units of the U.S. regulatory system. Also shown in Table 1 are the $14 \mathrm{C}$ DAC values contained 10 CFR 835 Appendix A (2007). Of particular note is that DACs for 14C particulates are two-to-three orders of magnitude smaller than the 14C DACs contained in 10 CFR 835 Appendix A. Monitoring programs which might utilize the most restrictive 10 CFR 835 DAC as a basis for workplace control, when in fact the source term would be a particulate instead of a gas or vapor, would seriously underestimate the significance of an intake based on air sampling data.

\subsection{Bioassay Programs}

Bioassay monitoring programs for $14 \mathrm{C}$ in workers typically rely on indirect bioassay using urine or fecal samples, with $14 \mathrm{C}$ converted to $\mathrm{CO} 2$, distillation, and then liquid scintillation counting.

Urine and fecal excretion fractions calculated using IMBA are shown in Table 2. For purposes of determining bioassay program design, intakes corresponding to 5-rem (the regulatory compliance level), 100 -mrem (the investigation level), and 10-mrem (the recording level) were calculated using the e(50). These intakes were then multiplied by the respective urine and fecal excretion fractions to give derived reference bioassay levels at various times post intake, results for which are shown as side-by-side comparisons for urine and feces in Figure 1.

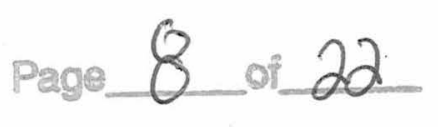


Table 2. Urine and fecal excretion fractions

\begin{tabular}{|c|c|c|c|c|c|c|c|c|}
\hline \multirow[b]{2}{*}{$\begin{array}{l}\text { Day Post } \\
\text { Intake }\end{array}$} & \multicolumn{4}{|c|}{ Urine Excretion Fraction } & \multicolumn{4}{|c|}{ Fecal Excretion Fraction } \\
\hline & Type $\mathrm{S}^{(\mathrm{a})}$ & Type $\mathrm{M}^{(\mathrm{a})}$ & Type $\mathrm{F}^{(\mathrm{a})}$ & SR-2 & Type $\mathrm{S}^{(\mathrm{a})}$ & Type $\mathrm{M}^{(\mathrm{a})}$ & Type $\mathrm{F}^{(\mathrm{a})}$ & SR-2 \\
\hline 1 & $5.21 \mathrm{E}-07$ & $9.31 \mathrm{E}-06$ & $6.99 \mathrm{E}-05$ & $1.68 \mathrm{E}-04$ & $1.13 \mathrm{E}-01$ & $1.00 \mathrm{E}-01$ & $1.15 \mathrm{E}-05$ & $3.01 \mathrm{E}-05$ \\
\hline 2 & $1.19 \mathrm{E}-06$ & $1.84 \mathrm{E}-05$ & $1.31 \mathrm{E}-04$ & $2.76 \mathrm{E}-04$ & $1.62 \mathrm{E}-01$ & $1.39 \mathrm{E}-01$ & 7.63E-05 & $1.73 \mathrm{E}-04$ \\
\hline 3 & $1.25 \mathrm{E}-06$ & $1.91 \mathrm{E}-05$ & $1.34 \mathrm{E}-04$ & $2.78 \mathrm{E}-04$ & $8.34 \mathrm{E}-02$ & $7.09 \mathrm{E}-02$ & $1.37 \mathrm{E}-04$ & $2.94 \mathrm{E}-04$ \\
\hline 5 & $1.22 \mathrm{E}-06$ & $1.86 \mathrm{E}-05$ & $1.30 \mathrm{E}-04$ & $2.69 \mathrm{E}-04$ & $1.39 \mathrm{E}-02$ & $1.18 \mathrm{E}-02$ & $1.78 \mathrm{E}-04$ & $3.70 \mathrm{E}-04$ \\
\hline 7 & $1.18 \mathrm{E}-06$ & $1.82 \mathrm{E}-05$ & $1.25 \mathrm{E}-04$ & $2.60 \mathrm{E}-04$ & $2.42 \mathrm{E}-03$ & $2.05 \mathrm{E}-03$ & $1.79 \mathrm{E}-04$ & $3.71 \mathrm{E}-04$ \\
\hline 14 & $1.07 \mathrm{E}-06$ & $1.67 \mathrm{E}-05$ & $1.11 \mathrm{E}-04$ & $2.30 \mathrm{E}-04$ & $4.74 \mathrm{E}-04$ & $3.89 \mathrm{E}-04$ & $1.59 \mathrm{E}-04$ & $3.31 \mathrm{E}-04$ \\
\hline 30 & 8.47E-07 & $1.36 \mathrm{E}-05$ & $8.41 \mathrm{E}-05$ & $1.75 \mathrm{E}-04$ & $3.30 \mathrm{E}-04$ & $2.55 \mathrm{E}-04$ & $1.21 \mathrm{E}-04$ & $2.51 \mathrm{E}-04$ \\
\hline 60 & $5.50 \mathrm{E}-07$ & $9.30 \mathrm{E}-06$ & $5.00 \mathrm{E}-05$ & $1.04 \mathrm{E}-04$ & $1.78 \mathrm{E}-04$ & $1.22 \mathrm{E}-04$ & $7.18 \mathrm{E}-05$ & $1.49 \mathrm{E}-04$ \\
\hline 90 & $3.62 \mathrm{E}-07$ & $6.42 \mathrm{E}-06$ & 2.97E-05 & $6.17 \mathrm{E}-05$ & $1.03 \mathrm{E}-04$ & $6.39 \mathrm{E}-05$ & 4.27E-05 & 8.87E-05 \\
\hline 180 & $1.27 \mathrm{E}-07$ & $2.38 \mathrm{E}-06$ & $6.25 \mathrm{E}-06$ & $1.30 \mathrm{E}-05$ & $3.68 \mathrm{E}-05$ & $1.59 \mathrm{E}-05$ & $8.98 \mathrm{E}-06$ & $1.86 \mathrm{E}-05$ \\
\hline 365 & 5.37E-08 & $5.51 \mathrm{E}-07$ & $2.53 \mathrm{E}-07$ & $5.26 \mathrm{E}-07$ & 2.19E-05 & $3.80 \mathrm{E}-06$ & $3.64 \mathrm{E}-07$ & $7.55 \mathrm{E}-07$ \\
\hline 730 & $3.63 \mathrm{E}-08$ & $6.18 \mathrm{E}-08$ & $4.53 \mathrm{E}-10$ & $9.42 \mathrm{E}-10$ & $1.46 \mathrm{E}-05$ & $4.25 \mathrm{E}-07$ & $6.51 \mathrm{E}-10$ & $1.35 \mathrm{E}-09$ \\
\hline 1825 & $1.52 \mathrm{E}-08$ & $1.22 \mathrm{E}-10$ & $2.60 \mathrm{E}-18$ & $5.41 \mathrm{E}-18$ & 4.61E-06 & $6.69 \mathrm{E}-10$ & $3.74 \mathrm{E}-18$ & 7.77E-18 \\
\hline 3650 & $5.99 \mathrm{E}-09$ & $6.39 \mathrm{E}-15$ & $4.80 \mathrm{E}-32$ & $9.96 \mathrm{E}-32$ & $8.12 \mathrm{E}-07$ & $2.04 \mathrm{E}-14$ & $6.89 \mathrm{E}-32$ & $1.43 \mathrm{E}-31$ \\
\hline
\end{tabular}

a) 5- $\mu \mathrm{m}$ AMAD particles

Based on the Figure 1 urine reference levels, a routine monitoring program for type $\mathrm{M}$ or S particulate $14 \mathrm{C}$ requires substantially greater analytical sensitivity than a monitoring program for type $\mathrm{F}$, or Vapor Class SR-2 14C. For comparable intake detection of type F, M, and S particulates, monitoring by urinalysis requires analytical capabilities nominally 2,100 , and 3000 times more sensitive, respectively, than analytical methods supporting SR-2 forms. A similar comparison of fecal excretion reference levels shows that fecal sampling after the first few days is relatively insensitive to discriminating between intakes of absorption types $\mathrm{M}$ and S, with essentially no capability for discriminating between SR-2 and type F. Examining the ratio of same-day urine and fecal excretion would be helpful in determining particulate absorption type. Given the uncertainties in absorption type for graphite particulates associated with decommissioning activities, a prudent response to intake monitoring following workplace indications of significant intake would be to obtain both fecal and urine samples. The relatively low levels of $14 \mathrm{C}$ in feces from natural background environmental exposure and excretion should not pose any interference with monitoring. The same cannot be said if urine sampling is relied upon for type $\mathrm{S}$ monitoring, because the $0.04 \mathrm{dpm} / \mathrm{mL}$ nominal background excretion exceeds the 100 -mrem reference level for urine excretion for all times post intake, and the 5-rem reference level for times greater than 180 days post intake.

While the above suggests bioassay for $14 \mathrm{C}$ may be quite challenging, the need for bioassay must be put in perspective with the magnitude of potential intake. Intake totaling the 350- $\mu \mathrm{Ci}$ ALI of type S $14 \mathrm{C}$ in graphite at the $2.4 \mu \mathrm{Ci} / \mathrm{g}$ mean concentration observed in Hanford reactor graphite, would require inhalation of $146 \mathrm{~g}$ of graphite. There is no realistic scenario which could result in such an intake, or for that matter a likely intake of even $1 \%$ of that magnitude, which would correspond to a dose of 50 mrem. Thus, bioassay monitoring for $14 \mathrm{C}$ from exposure to graphite may arguably not be a requirement. Unless source term characterization efforts show much higher concentrations than those historically observed, it would appear that the Hanford reactor decommissioning work would not require $14 \mathrm{C}$ bioassay.

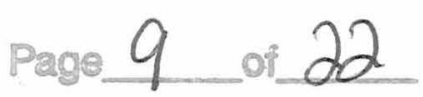




\subsection{References}

10 CFR 835 Appendix A. 2007. U.S. Department of Energy, Occupational Radiation Protection. U.S. Code of Federal Regulations. Accessed August 20, 2010 at http://www.gpoaccess.gov/cfr/

Electrical Power Research Institute (EPRI). 2006. Graphite Decommissioning Options for Graphite Treatment, Recycling, or Disposal, including a discussion of Safety-Related Issues. Concord: Electrical Power Research Institute.

International Commission on Radiological Protection (ICRP). 1974. Report of the task group on Reference Man. ICRP publication 23, Pergamom Press, New York.

International Commission on Radiological Protection (ICRP). 1994. "Dose coefficients for intakes of radionuclides by workers." (ICRP publication 68.) Annals of the ICRP, 24:4, Pergamon Press, New York.

International Commission on Radiological Protection (ICRP). 1995. "Age-dependent doses to members of the public from intakes of radionuclides: Part 4 inhalation dose coefficients." (ICRP publication 71.) Annals of the ICRP, 25:3-4, Pergamon Press, New York.

International Commission on Radiological Protection (ICRP). 2001. "ICRP Database of Dose Coefficients: Workers and Members of the Public." ICRP CD-1. Elsevier Science Ltd., Pergamon Press, New York.

International Commission on Radiological Protection (ICRP). 2002. "Basic Anatomical and Physiological Data for Use in Radiological Protection: Reference Values.” (ICRP publication 89.) Annals of the ICRP, 32:3-4, Pergamon Press, New York.

Miller R, Steffes J. Radionuclide Inventory and Source Terms for the Surplus Production Reactors at Hanford. Richland, WA: United Nuclear Corporation; UNI-3714, Rev. 1; 1987.

National Council on Radiation Protection and Measurements (NCRP). 1985. Carbon-14 in the Environment. NCRP Report No. 81. Bethesda, MD.

Paasch RA. 1985. A Compilation of Carbon-14 Data. Richland, WA: United Nuclear Corporation; UNI3499 .

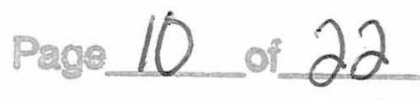


Figure 1. Urine and fecal excretion following single acute inhalation intake of ${ }^{14} \mathrm{C}$
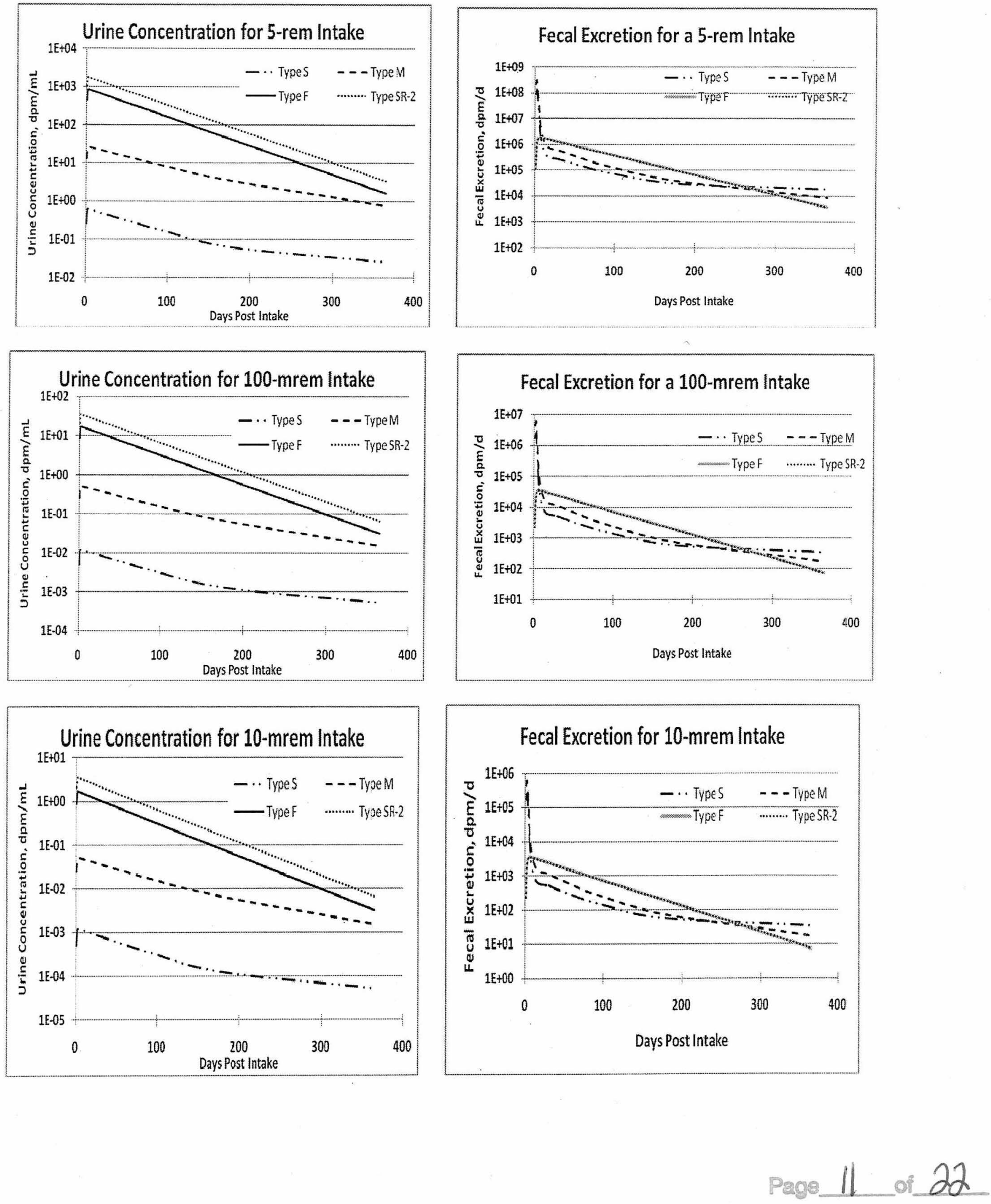
January 17,2011
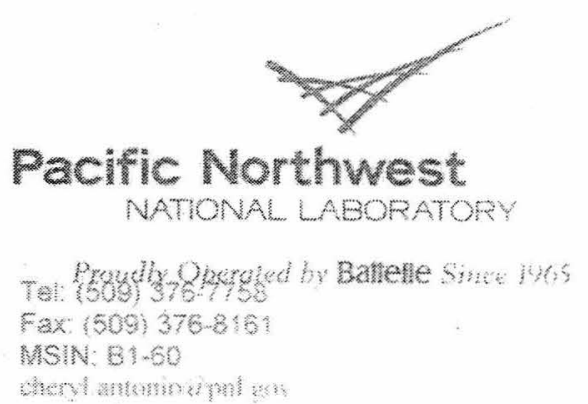

NATIONAL LABORATOR

Fax: $\{509\} 376316$

MSIN: 61.60

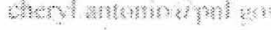

Eugene H. Carbaugh

Pacific Northwest National Laboratory

P.O. Box 999

Richland, WA. 99352

Dear Mr. Carbaugh:

Carbon-14 Performance Evaluation Samples submitted October 26, 2010

To evaluate GEL's capabilities for C-14 urinalyses as well as follow-up GEL's failure to pass the Department of Energy's Laboratory Accreditation Program (DOELAP) category I performance testing for $\mathrm{C}-14$ urinalyses, the Internal Dosimetry Program submitted 12 single blind urine samples for analysis. The samples were in $100 \mathrm{ml}$ nalgene containers, 7 were spiked at $167.0 \mathrm{dpm} / \mathrm{ml}$ and 5 were blanks (Attachment 1).

On November 9, $2010 \mathrm{GEL}$ reported the results (Attachment 2), activity was not detected in the five blank samples but C-14 was detected in the seven spiked samples. The MDA was estimated at $0.80 \mathrm{dpm} / \mathrm{ml}$ based on the results of the five blank samples. The seven samples that were spiked with $167.0 \mathrm{dpm} / \mathrm{ml}$ were reported with activity ranging from 131.0 through $161.0 \mathrm{dpm} / \mathrm{ml}$. The mean relative bias was -0.091 and the mean relative precision was reported at 0.063 . The Internal Dosimetry Program's (IDP) acceptance criteria for the mean relative bias is -0.20 to +0.20 and for the relative precision an absolute value less than or equal to 0.4 . The contractual detection level for $\mathrm{C}-14$ is $10 \mathrm{dpm} / \mathrm{ml}$. Therefore, all the performance criteria were met and the C-14 urinalysis was determined to be acceptable.

The DOELAP performance test acceptance criteria (DOE-STD-1112-98) for the relative bias statistic is -0.25 to +0.50 and the relative precision statistic less than or equal to 0.4 . A comparison of the GEL reported results with the DOELAP standards indicates that GEL likewise met the performance criteria for $\mathrm{C}-14$ analyses.

The sample matrix differed from the IDP and DOELAP samples in that the IDP samples were raw urine samples and the DOELAP samples were synthetic samples using urine salts. The levels of $\mathrm{C}-14$ activity in the IDP and DOELAP samples were similar. GEL technicians also observed a flaky precipitate in the DOELAP samples that they were 
Eugene H. Carbaugh

January 17, 2011

Page 2

unable to dissolve. The precipitate in the DOELAP samples most likely contributed to GEL's relative bias ranging from -0.51 to -0.65 for the 5 DOELAP samples.

Based on GEL's performance with the twelve samples submitted by IDP, the C-14 analysis was deemed acceptable and there is high expectation that GEL will meet the DOELAP performance criteria in the 2011 retesting.

Included is the summary report from GEL, with additional emails to clarify the count times, detector efficiencies and their internal quality control results (Attachment 3). Attachment 4 is communications concerning the DOELAP samples, their preparation and the observations of GEL staff.

Sincerely,

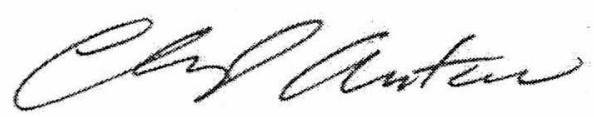

Cheryl Antonio, CHP

Senior Research Scientist

Internal Dosimetry

Radiation \& Health Technology

CLAVCLA/rab

Attachments

1. Bioassay Test Samples (8 pages)

2. QC Summary Report (1 page)

3. GEL Certificate of Analysis (29 pages)

4. Category 1 Sample Volumes (4 pages)

cc: File

LB w/o attachment 


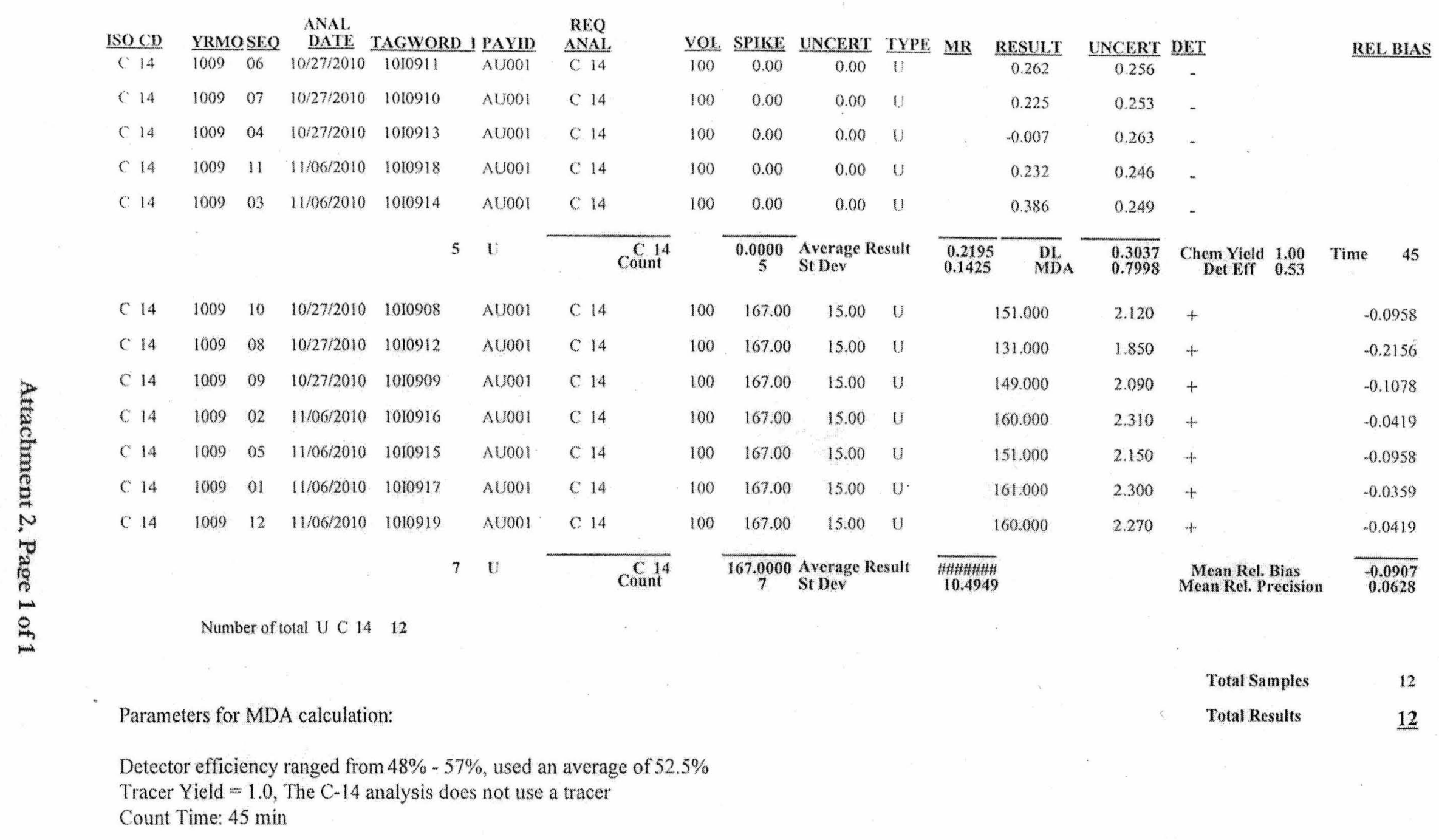


From:

Sent:

To:

Cc:

Subject:
Carbaugh, Eugene $\mathrm{H}$

Wednesday, February 02, 2011 10:35 AM

Baker, Steven C (PNNL); Barton, Clark B; Carbaugh, Eugene H; Carlson, Eric W; English, Robert G; Glines, Wayne; Haan, Thomas P; Hill, Robin L; Hilliard, James R; Jones, Robert A; Kaiser, Krista I; Kurtz, Jerry E; Lynch, Timothy P (PNNL); Rathbone, Bruce A; Ruiz, Theresa C MacLellan, Jay; Antonio, Cheryl L; Baker, Steven C (PNNL)

GEL performance on PNNL C-14 audit samples

Attached is the summary letter and summary data report for the carbon-14 QA audit samples we submitted to GEL in October and November. GEL met our contractual performance requirements and those of HPS N13.30 (i.e., the DOELAP criteria).

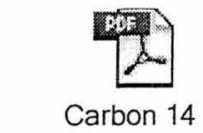

:rfEvalSmpls Oct20-

In a closely related vein, it looks like the problem that caused GEL to fail DOELAP performance testing for C-14 last year has been identified. Preliminary results of the retesting seemed to again show erratic performance by GEL that would have resulted in failure of the C-14 test. Discussions between GEL and Dave Sill at RESL (DOELAP) over the past couple of weeks have identified what appears to be a significant cause. RESL spikes with C-14 benzoate in synthetic urine and refrigerates its samples from time of preparation to time of analysis. GEL does not refrigerate their samples. In the time between receipt at GEL and analysis, microbial action within the artificial urine matrix has been found to result in degradation of the $\mathrm{C}-14$ benzoate causing inaccurate results. DOELAP is now advising that samples should be refrigerated upon receipt until analysis, and GEL is instituting such a procedure. GEL will be receiving another set of test samples from DOELAP now that the problem appears to be resolved.

Samples analyzed by GEL under the PROCRAD intercomparison program had not shown any similar problem. It turns out that PROCORAD apparently acidifies their samples before sending them. That prevents the microbial action.

Our samples were not spiked using benzoate, but rather a glucose matrix. Also, we used real urine and not the synthetic urine recipe that DOELAP uses. These may be contributing factors to our samples showing better performance than the DOELAP samples.

\section{Gene Carbaugh, CHP}

Staff Scientist and Internal Dosimetry Manager

Radiation \& Health Technology

Pacific Northwest National Laboratory

902 Battelle Boulevard

P.O. Box 999, MSIN B1-60

Richland, WA 99352 USA

Tel: $509-376-6632$

Fax: 509-376-8161

gene.carbaugh@pnl.gov

wWw.pnl.gov

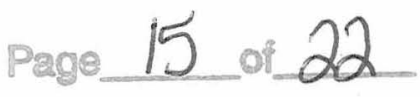




\section{Antonio, Cheryl L}

From:

Sent:

To:

Cc:

Subject:
Carbaugh, Eugene $\mathrm{H}$

Wednesday, February 02, 2011 10:12 AM

Bob Timm

MacLellan, Jay; Antonio, Cheryl L

C-14 audit data

Bob,

Attached is the summary letter and summary data page from our carbon-14 audit submittals of last October and November. From our perspective it looks like GEL has a negative bias but meets the contractual and HPS N13.30 performance criteria. I didn't provide all the other attachments, but if you want them I'il give them to you (most of the attachments was simply GEL's data report to us).

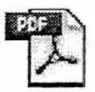

Carbon 14

:rfEvalSmpls Oct20.

\section{Gene Carbaugh, CHP}

Staff Scientist and Internal Dosimetry Manager

Radiation \& Health Technology

Pacific Northwest National Laboratory

902 Battelle Boulevard

P.O. Box 999, MSIN B1-60

Richland, WA 99352 USA

Tel: 509-376-6632

Fax: 509-376-8161

gene.carbaugh@pnl.gov

www.pnl.gov 
Antonio, Cheryl L

From:

Sent:

To:

Cc:

Subject:
Carbaugh, Eugene $\mathrm{H}$

Tuesday, February 01, 2011 2:18 PM

Bob Timm

MacLellen, Jay; Antonio, Cheryl L

RE: FW: Important Message from DOELAP

My congrats to you and Dave for the detective work. III buy you a beer next week!

\section{Gene Carbaugh}

Staff Scientist and Internal Dosimetry Manager

Pacific Northwest National Laboratory

From: Bob Timm [mailto:rdt@gel.com]

Sent: Tuesday, February 01, $20112: 15$ PM

To: Carbaugh, Eugene $\mathrm{H}$

Cc: MacLellan, Jay; Antonio, Chery! L

Subject: Re: FW: Important Message from DOELAP

I would be very surprised if Procorad is preserved haven't checked. I'll see if we still have this years lying around and test the $\mathrm{pH}$.

Acidification with $\mathrm{HNO} 3$ would theoretically produce $\mathrm{O} 2$ and losses would occur however, when I was trying to figure out our issue last year I did preserve some samples $\mathrm{h} \mathrm{HCL}$ and HNO3. The HCL preserved samples didn't analyze well and I couldn't get results. The HNO preserved one, got the same result as I did with unpreserved but it was still the wrong result. I didn't notice increaset losses.

We analyze environmental samples unpreserved ar our standards are typically in a $\mathrm{NaOH}$ preserved media. Sounds like refrigeration and cold shipping may be the best prese vative.

Bob

On 2/1/2011 5:08 PM, Carbaugh, Eugene $H$ wrote

I was wondering what the impact of cidification be on the sample, too. Does Procorad send acid-preserved samples?

\section{Gene Carbaugh}

Staff Scientist and Internal Dos netry Manoge.

Pacific Northwest National Labc

From: Bob Timm [mailto:rdt@gel.con]

Sent: Tuesday, February 01, 2011 2:03 PM

To: Carbaugh, Eugene $\mathrm{H}$

Cc: MacLellan, Jay; Antonio, Cheryl L.

Subject: Re: FW: Important Messa from DOEL

Definitely.

I've been working with Dave Sill ove the nast week. this. I analyzed this years samples and got results all over the place like last year. I didn't want to indly report and fail again so I called Dave. He was very open to the problem and helpful in collaborating to solve this 
We'll be adding a refrigeration requirement to our $\mathrm{C}-14$ samples.

It's interesting that the Procorad samples work with ont refrigeration as did the samples you sent us however, the type of C-14 standard used is probably the main contribu ing factor.

Bob

On 2/1/2011 4:59 PM, Carbaugh, Euzene H wrote:

The below may be a contributing fo or in our $\mathrm{C}-14$ oblem. Bob?

\section{Gene Carbaugh}

Staff Scientist and Internal Dosinetry Manager

Pacific Northwest National Laboratory

From: sillds@id.doe.gov [mailto:sill @id.doe.gor]

Sent: Tuesday, February 01, $2011: 77$ PM

To: hickman3@llnl.gov; Carbaugh, _ugene H; raogr ornl.gov; capotte@sandia.gov

Subject: Important Message from DOELAP

Gentlemen of the OSB,

This was some interesting detec!ie work and through you guys should know. Below is the e-mail that was sent to the participants.

Left me know if you have any git wions....

Dear Participants,

It has come to our attention that setain laborates are not refrigerating the DOELAP SU samples after being received in their laboratory.

The SU solutions used for C-14 analyses shouk be refrigerated immediately upon receipt and kept refrigerated until the $\mathrm{C}-14$ analyses are completed.

If the SU solutions are left unrefficrated for long periods of time prior to the analysis of $\mathrm{C}-14$, the subsequent microbial action will lead to des lation of $10 .-14$ labeled benzoate which will cause inaccurate analytical results for $\mathrm{C}-14$.

DOELAP has verified that these siutions are sthle for the entire length of the test session if they are refrigerated.

If you have any questions or if y have exper. ed this problem and would like a replacement set of SU samples for C-14, please contac: en the nut $\because$ or email listed below.

Thank You,

David Sill

Senior Technical Manager -Chur istry

U.S. Department of Energy

Radiological and Environmenta! ciences Labo:ci. ory

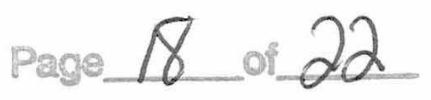


1955 Freemont Drive, MS 4149

Idaho Falls, ID 83415

sillds@,id.doe.gov

208-526-8031

CONFIDENTIALITY NOTICE: This e-mail and any files transmitted with it are the property of The GEL Group, Inc. and its affiliates. Al ghts, includin without limitation copyright, are reserved. The proprietary information contained in this e-n il message, and any files transmitted with it, is intended for the use of the recipient(s) named above. If the rader of this e nail is not the intended recipient, you are hereby notified that you have received this e-mail in mor and that ay review, distribution or copying of this e-mail or any files transmitted with it is strictly prohibited. If you have received this e-mail in error, please notify the sender immediately and delete the original message and any files transmitted. The unauthorized use of this e-mail or any files transmitted with it is pited and in aimed by The GEL Group, Inc. and its affiliates.

CONFIDENTIALITY NOTICE: his e-mil ant any files transmitted with it are the property of The GEL Group, Inc. and its affiliates. All ights, includin without limitation copyright, are reserved. The proprietary information contained in this e-n: 1 message, and any files transmitted with it, is intended for the use of the recipient(s) named above. If the rader of this e-mail is not the intended recipient, you are hereby notified that you have received this e-mail in cror and that any review, distribution or copying of this e-mail or any files

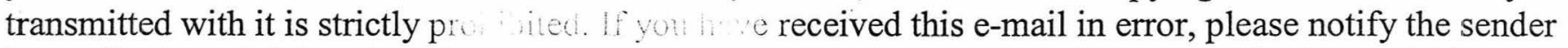
immediately and delete the orig I message and my files transmitted. The unauthorized use of this e-mail or any files transmitted with it is plibited and saimed by The GEL Group, Inc. and its affiliates. 


\section{Antonio, Cheryl L}

$\begin{array}{ll}\text { From: } & \text { Bob Timm [rdt@gel.com] } \\ \text { Sent: } & \text { Monday, June 21, 2010 10:16 AM } \\ \text { To: } & \text { MacLellan, Jay } \\ \text { Cc: } & \text { Carbaugh, Eugene H; stan.morton@gel.com; Antonio, Cheryl L; Jannie Shaw- } \\ & \text { Busby@gel.com; 'marletgm@id.doe.gov' } \\ \text { Subject: } & \text { Re: TRIM: Re: FW: HANFORD INDIRECT RADIOBIOASSAY RESULTS FOR DOELAP } \\ & \text { TEST SESSION 13 }\end{array}$

PROCORAD is real urine and doesn't have the precipitate in them.

There was only one other lab in the DOELAP report. They achieved a passing result and also had a negative bias at $-17 \%$.

We still have the original samples and we are able to request new samples from DOELAP once we've figured out our issue.

H3 was performed from the same sample container and had no problems (not surprising).

Bob

On 6/21/2010 1:08 PM, MacLellan, Jay wrote:

If I remember right, the PROCORAD samples use purified urine. There wouldn't be any precipitates. It will be interesting to hear if other DOELAP participants had similar problems.

Jay MacLellan

509-376-7247

jay.maclellan@pnl.gov

From: Bob Timm [mailto:rdt@gel.com]

Sent: Monday, June 21, 2010 4:25 AM

To: Carbaugh, Eugene $\mathrm{H}$

Cc: stan.morton@gel.com; MacLellan, Jay; Antonio, Cheryl L; Jannie Shaw-Busby@gel.com

Subject: TRIM: Re: FW: HANFORD INDIRECT RADIOBIOASSAY RESULTS FOR DOELAP TEST SESSION 13

Thanks Gene, we also got word from DOELAP.

This was the first time we'd performed C-14 for DOELAP or at least the first time the samples had C-14 activity in them. On these specific samples, we were not able to get consistent results from one bottle to the next. There was a flaky precipitant in all bottles and I suspect it was holding a good bit of the $\mathrm{C}-14$. We don't use a large enough aliquot of urine to overcome the non-homogenous nature of this sample having the precipitant.

We've performed well in the past on PROCORAD C-14 PE samples and don't have problems with Matrix Spikes and Lab Control Samples. I suspect this is more a sample matrix problem than a method problem.

We've opened a corrective action internally and we'll let you know of our findings.

Bob

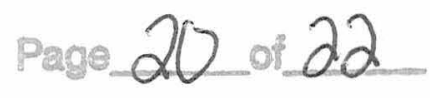


On 6/18/2010 4:58 PM, Carbaugh, Eugene H wrote:

Stan, Bob, Jay,

We received the results of the DOELAP indirect radiobioassay performance testing. The transmittal to us and the full report are attached. GEL is identified as Lab 2 in the Session 13 report. GEL passed all tests except C-14 in urine, for which GEL consistently showed a negative bias ranging from -0.51 to -0.65 for the 5 samples (acceptable range for bias is -0.25 to 0.5 ). Lab 4 was also tested for $\mathrm{C}-14$ and showed a consistent negative bias for their 5 samples of about -0.16 to -0.2 .

We are not currently running C-14 as any kind of routine analysis and in fact haven't run any since 1998, so I'm not particularly worried about this. However $\mathrm{C}-14$ is one of the nuclides for which we could have a potential need due to lab or cleanup work. Jay and I will be discussing this when he's back next week. At this point I just wanted to provide you with the DOELAP results.

\section{Gene Carbaugh}

Staff Scientist and Internal Dosimetry Manager

Pacific Northwest National Laboratory

From: marletgm@id.doe.gov [mailto:marletgm@id.doe.gov]

Sent: Thursday, June 17, 2010 10:14 AM

To: Baker, Steven C (PNNL)

Cc: Steve.Zobel@hq.doe.gov; Glines, Wayne M; Carbaugh, Eugene H

Subject: HANFORD INDIRECT RADIOBIOASSAY RESULTS FOR DOELAP TEST SESSION 13

Steven:

Attached is the cover letter and the indirect radiobioassay results for DOELAP Test Session 13. All performance evaluation results are listed by Lab Code. Please refer to the cover letter for your Lab Code. A quick review of performance is provided in the Summary Report section, a visual comparison of performance with the other participants is presented in the Performance Graphs section, and the result for each determination is presented in the Detailed Comparison section. Bookmarks are provided to assist in navigating through the full report. Thank you for your continued support of the DOELAP program. The DOELAP Team wishes you much success. Please contact me if you have any questions.

Best regards,

Guy

Guy M. Marlette, Chemist

Performance Evaluation Program Administrator

DOE Laboratory Accreditation Program

U.S. Department of Energy

1955 Fremont Avenue, MS-4149

Idaho Falls, ID 83415-4149

Phone: 208-526-2532

Fax: $208-526-2548$

Email: marletgm@id.doe.gov

CONFIDENTIALITY NOTICE: This e-mail and any files transmitted with it are the property of The GEL Group, Inc. and its affiliates. All rights, including without limitation copyright, are reserved. The proprietary 
information contained in this e-mail message, and any files transmitted with it, is intended for the use of the recipient(s) named above. If the reader of this e-mail is not the intended recipient, you are hereby notified that you have received this e-mail in error and that any review, distribution or copying of this e-mail or any files transmitted with it is strictly prohibited. If you have received this e-mail in error, please notify the sender immediately and delete the original message and any files transmitted. The unauthorized use of this e-mail or any files transmitted with it is prohibited and disclaimed by The GEL Group, Inc. and its affiliates.

CONFIDENTIALITY NOTICE: This e-mail and any files transmitted with it are the property of The GEL Group, Inc. and its affiliates. All rights, including without limitation copyright, are reserved. The proprietary information contained in this e-mail message, and any files transmitted with it, is intended for the use of the recipient(s) named above. If the reader of this e-mail is not the intended recipient, you are hereby notified that you have received this e-mail in error and that any review, distribution or copying of this e-mail or any files transmitted with it is strictly prohibited. If you have received this e-mail in error, please notify the sender immediately and delete the original message and any files transmitted. The unauthorized use of this e-mail or any files transmitted with it is prohibited and disclaimed by The GEL Group, Inc. and its affiliates. 
APPENDIX A

\section{QUALITY CONTROL SAMPLE RESULTS}

(Historical File Only) 


\begin{tabular}{|c|c|c|c|c|c|c|c|c|c|c|c|c|c|c|c|c|c|}
\hline ISO CD & \multicolumn{2}{|c|}{ YRMOSEQ } & $\begin{array}{l}\text { ANAL } \\
\text { DATE I }\end{array}$ & TAGWORD & I PAYID & $\begin{array}{c}\text { REQ } \\
\text { ANAL }\end{array}$ & VOL & $\underline{\text { SPIKE }}$ & UNCERT & TYPE & $\underline{\mathrm{MR}}$ & RESULT & UNCERT & DET & & \multicolumn{2}{|c|}{$\underline{\text { REL BIAS }}$} \\
\hline AM241 & 1101 & 14 & $01 / 31 / 2011$ & 11A0691 & YH402 & IPA & 145 & 0.0000 & 0.0000 & F & $\mathrm{J}$ & -0.0115 & 0.0975 & - & & & \\
\hline AM241 & 1101 & 12 & $01 / 31 / 2011$ & $11 \mathrm{~A} 0687$ & 99200 & IPA & 181 & 0.0000 & 0.0000 & F & $\mathrm{J}$ & -0.0285 & 0.0555 & - & & & \\
\hline AM241 & 1101 & 13 & $01 / 31 / 2011$ & $11 \mathrm{~A} 0683$ & 99216 & IPA & 114 & 0.0000 & 0.0000 & $\mathrm{~F}$ & $\mathrm{~J}$ & -0.0246 & 0.0612 & - & & & \\
\hline AM241 & 1101 & 11 & $01 / 31 / 2011$ & $11 \mathrm{~A} 0695$ & 99159 & IPA & 25 & 0.0000 & 0.0000 & F & $\mathrm{J}$ & -0.0140 & 0.0935 & - & & & \\
\hline \multirow[t]{2}{*}{ AM241 } & 1101 & 15 & 02/18/2011 & $11 \mathrm{~A} 0920$ & 99204 & IPA & 99 & 0.0000 & 0.0000 & $\mathrm{~F}$ & $\mathrm{~J}$ & 0.0103 & 0.1100 & - & & & \\
\hline & & & & 5 & $\mathbf{F}$ & \multicolumn{2}{|l|}{$\begin{array}{l}\text { AM241 } \\
\text { Count }\end{array}$} & $\begin{array}{c}0.0000 \\
5\end{array}$ & \multicolumn{2}{|c|}{$\begin{array}{l}\text { Average Result } \\
\text { St Dev }\end{array}$} & $\begin{array}{l}-0.0137 \\
0.0152\end{array}$ & $\underset{\text { MDA }}{\text { DL }}$ & $\begin{array}{l}0.0323 \\
0.0787\end{array}$ & $\begin{array}{c}\text { Chem Yield } \\
\text { Det Eff }\end{array}$ & $\begin{array}{l}0.86 \\
0.39\end{array}$ & Time & 960 \\
\hline AM241 & 1101 & 07 & $01 / 31 / 2011$ & 11A0689 & 99204 & IPA & 212 & 1.6300 & 0.0075 & F & $\mathrm{J}$ & 1.2700 & 0.2800 & + & & & .2209 \\
\hline AM241 & 1101 & 08 & $01 / 31 / 2011$ & 11A0685 & 99217 & IPA & 82 & 1.6300 & 0.0075 & F & $\mathrm{J}$ & 1.3400 & 0.2800 & + & & & .1779 \\
\hline AM241 & 1101 & 06 & $01 / 31 / 2011$ & $11 \mathrm{~A} 0693$ & 99120 & IPA & 88 & 1.6300 & 0.0075 & $\mathrm{~F}$ & $\mathrm{~J}$ & 1.3300 & 0.2800 & + & & & .1840 \\
\hline AM241 & 1101 & 10 & 02/18/2011 & $11 \mathrm{~A} 0919$ & 99217 & IPA & 92 & 1.6300 & 0.0075 & $\mathrm{~F}$ & $\mathrm{~J}$ & 1.7200 & 0.3560 & + & & & 0.0552 \\
\hline \multirow[t]{3}{*}{ AM241 } & 1101 & 09 & $02 / 18 / 2011$ & 11A0921 & 99120 & IPA & 42 & 1.6300 & 0.0075 & F & $\mathrm{J}$ & 1.4900 & 0.3090 & + & & & .0859 \\
\hline & & & & 5 & $\mathbf{F}$ & $\underset{\text { Count }}{\text { AM241 }}$ & & $\begin{array}{c}1.6300 \\
5\end{array}$ & $\begin{array}{l}\text { Average R } \\
\text { St Dev }\end{array}$ & esult & $\begin{array}{l}1.4300 \\
0.1812\end{array}$ & & & $\begin{array}{l}\text { Mean Rel. I } \\
\text { Mean Rel. Pr }\end{array}$ & $\begin{array}{l}\text { Bias } \\
\text { recision }\end{array}$ & & $\begin{array}{l}0.1227 \\
0.1112\end{array}$ \\
\hline & \multicolumn{3}{|c|}{ Number of total F AM241 } & 10 & & & & & & & & & & & & & \\
\hline PU238 & 1101 & 14 & $01 / 31 / 2011$ & 11A0691 & YH402 & IPA & 145 & 0.0000 & 0.0000 & $\mathrm{~F}$ & $\mathrm{~J}$ & -0.0034 & 0.0106 & - & & & \\
\hline PU238 & 1101 & 11 & $01 / 31 / 2011$ & $11 \mathrm{~A} 0695$ & 99159 & IPA & 25 & 0.0000 & 0.0000 & $\mathrm{~F}$ & $\mathrm{~J}$ & 0.0059 & 0.0186 & - & & & \\
\hline PU238 & 1101 & 12 & $01 / 31 / 2011$ & $11 \mathrm{~A} 0687$ & 99200 & IPA & 181 & 0.0000 & 0.0000 & $\mathrm{~F}$ & $\mathrm{~J}$ & 0.0100 & 0.0092 & - & & & \\
\hline PU238 & 1101 & 13 & $01 / 31 / 2011$ & $11 \mathrm{~A} 0683$ & 99216 & IPA & 114 & 0.0000 & 0.0000 & $\mathrm{~F}$ & $\mathrm{~J}$ & 0.0086 & 0.0080 & - & & & \\
\hline \multirow[t]{2}{*}{ PU238 } & 1101 & 15 & $02 / 18 / 2011$ & $11 \mathrm{~A} 0920$ & 99204 & IPA & 99 & 0.0000 & 0.0000 & $\mathrm{~F}$ & $\mathrm{~J}$ & 0.0053 & 0.0254 & - & & & \\
\hline & & & & 5 & $\mathbf{F}$ & \multicolumn{2}{|l|}{$\begin{array}{c}\text { PU238 } \\
\text { Count }\end{array}$} & $\begin{array}{c}0.0000 \\
5\end{array}$ & \multicolumn{2}{|c|}{$\begin{array}{l}\text { Average Result } \\
\text { St Dev }\end{array}$} & $\begin{array}{c}0.0053 \\
0.0052\end{array}$ & $\begin{array}{l}\text { DL } \\
\text { MDA }\end{array}$ & $\begin{array}{l}0.0111 \\
0.0368\end{array}$ & $\begin{array}{l}\text { Chem Yield } \\
\text { Det Eff }\end{array}$ & $\begin{array}{l}0.83 \\
0.39\end{array}$ & Time & 960 \\
\hline PU238 & 1101 & 08 & $01 / 31 / 2011$ & $11 \mathrm{~A} 0685$ & 99217 & IPA & 82 & 0.8440 & 0.0050 & $\mathrm{~F}$ & $J$ & 0.7160 & 0.0934 & + & & & .1517 \\
\hline PU238 & 1101 & 07 & $01 / 31 / 2011$ & $11 \mathrm{~A} 0689$ & 99204 & IPA & 212 & 0.8440 & 0.0050 & $\mathrm{~F}$ & $\mathrm{~J}$ & 0.6980 & 0.1210 & + & & & .1730 \\
\hline PU238 & 1101 & 06 & $01 / 31 / 2011$ & $11 \mathrm{~A} 0693$ & 99120 & IPA & 88 & 0.8440 & 0.0050 & F & $J$ & 0.8470 & 0.1130 & + & & & .0036 \\
\hline PU238 & 1101 & 10 & $02 / 18 / 2011$ & 11A0919 & 99217 & IPA & 92 & 0.8440 & 0.0050 & $\mathrm{~F}$ & $\mathrm{~J}$ & 0.8300 & 0.1080 & + & & & .0166 \\
\hline \multirow[t]{2}{*}{ PU238 } & 1101 & 09 & $02 / 18 / 2011$ & $11 \mathrm{~A} 0921$ & 99120 & IPA & 42 & 0.8440 & 0.0050 & $\mathrm{~F}$ & $J$ & 0.7960 & 0.0998 & + & & & 0.0569 \\
\hline & & & & 5 & $\mathbf{F}$ & $\begin{array}{l}\text { PU238 } \\
\text { Count }\end{array}$ & & $\begin{array}{c}0.8440 \\
5\end{array}$ & \multicolumn{2}{|c|}{$\begin{array}{l}\text { Average Result } \\
\text { St Dev }\end{array}$} & $\begin{array}{c}0.7774 \\
0.0671\end{array}$ & & & $\begin{array}{r}\text { Mean Rel. I } \\
\text { Mean Rel. Pr }\end{array}$ & $\begin{array}{l}\text { Bias } \\
\text { recision }\end{array}$ & & $\begin{array}{l}0.0789 \\
0.0795\end{array}$ \\
\hline
\end{tabular}




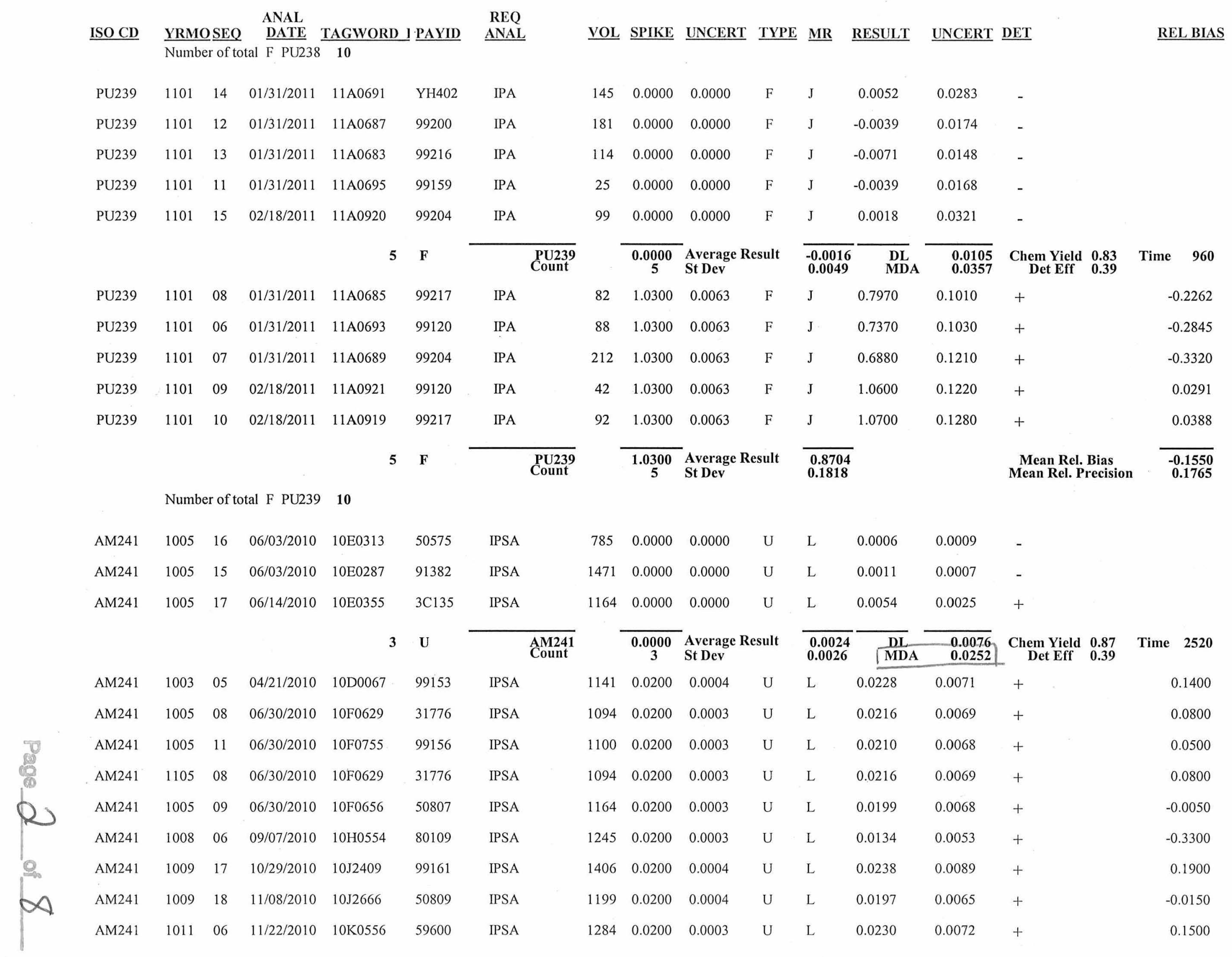




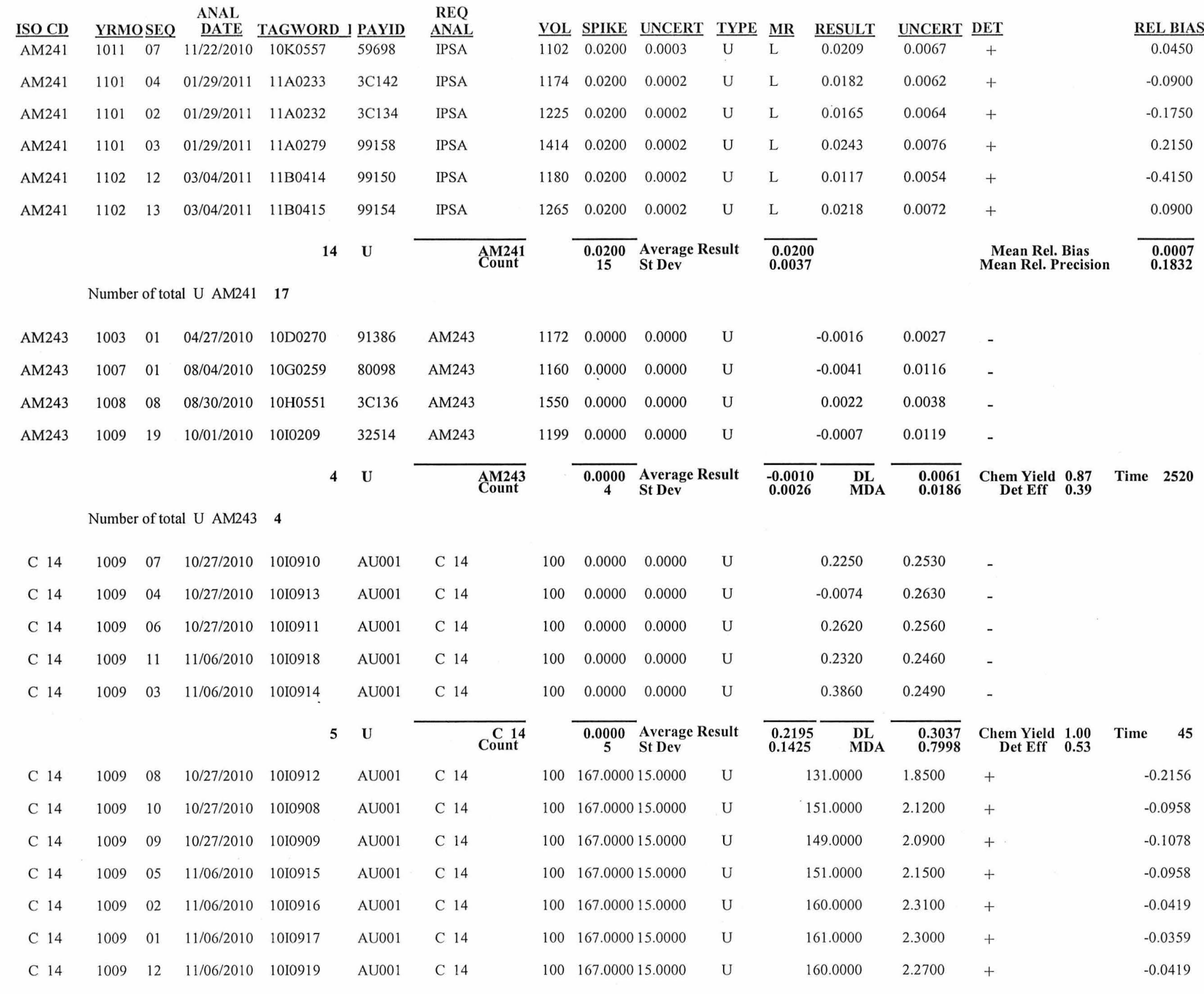




\begin{tabular}{|c|c|c|c|c|c|c|c|c|c|c|c|}
\hline$\underline{\text { ISO CD }}$ & $\underline{\text { YRMO }} \underline{\text { SEQ }}$ & $\begin{array}{l}\text { ANAL } \\
\text { DATE }\end{array}$ & TAGWORD & I PAYID & $\begin{array}{c}\text { REQ } \\
\text { ANAL }\end{array}$ & VOL & $\underline{\text { SPIKE }}$ & UNCERT TYPE & $\underline{\text { RESULT }}$ & UNCERT DET & $\underline{\text { REL BIAS }}$ \\
\hline & & & 7 & U & $\underset{\text { Count }}{\mathrm{C} 14}$ & & $\begin{array}{c}167.0000 \\
7\end{array}$ & $\begin{array}{l}\text { Average Result } \\
\text { St Dev }\end{array}$ & $\begin{array}{l}\# \# \# \# \# \# \\
10.4949\end{array}$ & $\begin{array}{l}\text { Mean Rel. Bias } \\
\text { Mean Rel. Precision }\end{array}$ & $\begin{array}{l}-0.0907 \\
0.0628\end{array}$ \\
\hline
\end{tabular}

Number of total U C $14 \quad 12$

\begin{tabular}{|c|c|c|c|c|c|c|c|c|c|c|c|c|c|}
\hline PU238 & 1003 & 05 & $04 / 21 / 2010$ & 10D0067 & 99153 & IPSA & 1141 & 0.0000 & 0.0000 & $\mathrm{U}$ & $\mathrm{L}$ & -0.0004 & 0.0022 \\
\hline PU238 & 1005 & 15 & $06 / 03 / 2010$ & $10 \mathrm{E} 0287$ & 91382 & IPSA & 1471 & 0.0000 & 0.0000 & $\mathrm{U}$ & $\mathrm{L}$ & -0.0012 & 0.0020 \\
\hline PU238 & 1005 & 16 & $06 / 03 / 2010$ & $10 \mathrm{E} 0313$ & 50575 & IPSA & 785 & 0.0000 & 0.0000 & $\mathrm{U}$ & $\mathrm{L}$ & 0.0000 & 0.0017 \\
\hline PU238 & 1005 & 17 & $06 / 14 / 2010$ & $10 \mathrm{E} 0355$ & $3 C 135$ & IPSA & 1164 & 0.0000 & 0.0000 & $\mathrm{U}$ & $\mathrm{L}$ & -0.0007 & 0.0022 \\
\hline PU238 & 1005 & 11 & $06 / 30 / 2010$ & $10 \mathrm{~F} 0755$ & 99156 & IPSA & 1100 & 0.0000 & 0.0000 & $\mathrm{U}$ & $\mathrm{L}$ & 0.0028 & 0.0037 \\
\hline PU238 & 1005 & 08 & $06 / 30 / 2010$ & $10 \mathrm{~F} 0629$ & 31776 & IPSA & 1094 & 0.0000 & 0.0000 & $\mathrm{U}$ & $\mathrm{L}$ & 0.0012 & 0.0039 \\
\hline PU238 & 1005 & 09 & $06 / 30 / 2010$ & $10 \mathrm{~F} 0656$ & 50807 & IPSA & 1164 & 0.0000 & 0.0000 & $\mathrm{U}$ & $\mathrm{L}$ & -0.0002 & 0.0023 \\
\hline PU238 & 1008 & 06 & 09/07/2010 & $10 \mathrm{H} 0554$ & 80109 & IPSA & 1245 & 0.0000 & 0.0000 & $\mathrm{U}$ & $\mathrm{L}$ & 0.0048 & 0.0028 \\
\hline PU238 & 1009 & 17 & $10 / 29 / 2010$ & $10 \mathrm{~J} 2409$ & 99161 & IPSA & 1406 & 0.0000 & 0.0000 & $\mathrm{U}$ & $\mathrm{L}$ & 0.0000 & 0.0009 \\
\hline PU238 & 1009 & 18 & $11 / 08 / 2010$ & $10 \mathrm{~J} 2666$ & 50809 & IPSA & 1199 & 0.0000 & 0.0000 & $\mathrm{U}$ & $\mathrm{L}$ & 0.0012 & 0.0011 \\
\hline PU238 & 1011 & 06 & $11 / 22 / 2010$ & $10 \mathrm{~K} 0556$ & 59600 & IPSA & 1284 & 0.0000 & 0.0000 & $\mathrm{U}$ & $\mathrm{L}$ & 0.0011 & 0.0015 \\
\hline PU238 & 1011 & 07 & $11 / 22 / 2010$ & $10 \mathrm{~K} 0557$ & 59698 & IPSA & 1102 & 0.0000 & 0.0000 & $\mathrm{U}$ & $\mathrm{L}$ & 0.0011 & 0.0014 \\
\hline PU238 & 1101 & 04 & $01 / 28 / 2011$ & $11 \mathrm{~A} 0233$ & $3 \mathrm{C} 142$ & IPSA & 1174 & 0.0000 & 0.0000 & $\mathrm{U}$ & $\mathrm{L}$ & 0.0005 & 0.0039 \\
\hline PU238 & 1101 & 03 & $01 / 28 / 2011$ & $11 \mathrm{~A} 0279$ & 99158 & IPSA & 1414 & 0.0000 & 0.0000 & $\mathrm{U}$ & $\mathrm{L}$ & -0.0019 & 0.0048 \\
\hline PU238 & 1101 & 02 & $01 / 28 / 2011$ & $11 \mathrm{~A} 0232$ & $3 \mathrm{C} 134$ & IPSA & 1225 & 0.0000 & 0.0000 & $\mathrm{U}$ & $\mathrm{L}$ & -0.0019 & 0.0039 \\
\hline PU238 & 1102 & 12 & $03 / 04 / 2011$ & 11B0414 & 99150 & IPSA & 1180 & 0.0000 & 0.0000 & $\mathrm{U}$ & $\mathrm{L}$ & -0.0006 & 0.0024 \\
\hline PU238 & 1102 & 13 & $03 / 04 / 2011$ & 11B0415 & 99154 & IPSA & 1265 & 0.0000 & 0.0000 & $\mathrm{U}$ & $\mathrm{L}$ & 0.0037 & 0.0032 \\
\hline
\end{tabular}

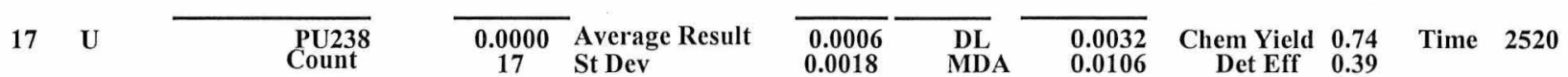

Number of total U PU238 17

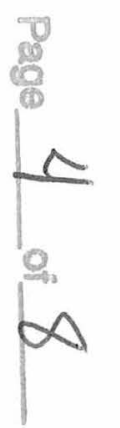

\begin{tabular}{|c|c|c|c|c|c|c|c|c|c|c|c|c|c|c|c|c|c|}
\hline PU239 & 1005 & 15 & $06 / 03 / 2010$ & $10 \mathrm{E} 0287$ & 91382 & IPSA & 1471 & 0.0000 & 0.0000 & $\mathrm{U}$ & $\mathrm{L}$ & 0.0026 & 0.0019 & - & & & \\
\hline PU239 & 1005 & 16 & $06 / 03 / 2010$ & $10 \mathrm{E} 0313$ & 50575 & IPSA & 785 & 0.0000 & 0.0000 & $\mathrm{U}$ & $\mathrm{L}$ & 0.0003 & 0.0027 & - & & & \\
\hline \multirow[t]{2}{*}{ PU239 } & 1005 & 17 & $06 / 14 / 2010$ & $10 \mathrm{E} 0355$ & $3 \mathrm{C} 135$ & IPSA & 1164 & 0.0000 & 0.0000 & U & $\mathrm{L}$ & -0.0013 & 0.0031 & - & & & \\
\hline & & & & 3 & U & $\begin{array}{c}\text { PU239 } \\
\text { Count }\end{array}$ & & $\begin{array}{c}0.0000 \\
3\end{array}$ & $\begin{array}{l}\text { Average } \\
\text { St Dev }\end{array}$ & Result & $\begin{array}{c}0.0005 \\
0.0020\end{array}$ & $\frac{\text { DL }}{\text { MDA }}$ & $\begin{array}{l}0.0057 \\
0.0232 \\
\end{array}$ & $\begin{array}{c}\text { Chem Yield } \\
\text { Det Eff }\end{array}$ & $\begin{array}{l}0.74 \\
0.39\end{array}$ & Time & e 2520 \\
\hline PU239 & 1003 & 05 & $04 / 21 / 2010$ & 10D0067 & 99153 & IPSA & 1141 & 0.0200 & 0.0005 & U & $\mathrm{L}$ & 0.0258 & 0.0070 & + & & & 0.2900 \\
\hline PU239 & 1005 & 08 & $06 / 30 / 2010$ & $10 \mathrm{~F} 0629$ & 31776 & IPSA & 1094 & 0.0200 & 0.0004 & $\mathrm{U}$ & $\mathrm{L}$ & 0.0101 & 0.0049 & + & & & -0.4950 \\
\hline
\end{tabular}




\begin{tabular}{|c|c|c|c|c|c|c|c|c|c|c|c|c|c|c|c|}
\hline ISO CD & $\underline{\text { YRMC }}$ & SEQ & $\begin{array}{l}\text { ANAL } \\
\text { DATE I }\end{array}$ & TAGWORD & PAYID & $\begin{array}{c}\text { REQ } \\
\text { ANAL } \\
\end{array}$ & VOL & $\underline{\text { SPIKE }}$ & UNCERT & TYPE & $\underline{\mathrm{MR}}$ & RESULT & UNCERT & DET & REL BIAS \\
\hline PU239 & 1005 & 11 & $06 / 30 / 2010$ & 10F0755 & 99156 & $\overline{I P S A}$ & 1100 & 0.0200 & 0.0004 & $\mathrm{U}$ & $\overline{\mathrm{L}}$ & $\overline{0.0157}$ & 0.0067 & + & -0.2150 \\
\hline PU239 & 1005 & 09 & 06/30/2010 & $10 \mathrm{~F} 0656$ & 50807 & IPSA & 1164 & 0.0200 & 0.0004 & U & $\mathrm{L}$ & 0.0160 & 0.0058 & + & -0.2000 \\
\hline PU239 & 1008 & 06 & 09/07/2010 & $10 \mathrm{H} 0554$ & 80109 & IPSA & 1245 & 0.0200 & 0.0004 & U & $\mathrm{L}$ & 0.0139 & 0.0047 & + & -0.3050 \\
\hline PU239 & 1009 & 17 & $10 / 29 / 2010$ & $10 \mathrm{~J} 2409$ & 99161 & IPSA & 1406 & 0.0200 & 0.0005 & U & L & 0.0244 & 0.0064 & + & 0.2200 \\
\hline PU239 & 1009 & 18 & $11 / 08 / 2010$ & $10 \mathrm{~J} 2666$ & 50809 & IPSA & 1199 & 0.0200 & 0.0005 & U & $\mathrm{L}$ & 0.0307 & 0.0067 & + & 0.5350 \\
\hline PU239 & 1011 & 06 & $11 / 22 / 2010$ & $10 \mathrm{~K} 0556$ & 59600 & IPSA & 1284 & 0.0200 & 0.0004 & $\mathrm{U}$ & $\mathrm{L}$ & 0.0145 & 0.0046 & + & -0.2750 \\
\hline PU239 & 1011 & 07 & $11 / 22 / 2010$ & 10K0557 & 59698 & IPSA & 1102 & 0.0200 & 0.0004 & $\mathrm{U}$ & $\mathrm{L}$ & 0.0221 & 0.0058 & + & 0.1050 \\
\hline PU239 & 1101 & 04 & $01 / 28 / 2011$ & $11 \mathrm{~A} 0233$ & $3 \mathrm{C} 142$ & IPSA & 1174 & 0.0200 & 0.0003 & $\mathrm{U}$ & $\mathrm{L}$ & 0.0259 & 0.0061 & + & 0.2950 \\
\hline PU239 & 1101 & 02 & $01 / 28 / 2011$ & 11A0232 & $3 \mathrm{C} 134$ & IPSA & 1225 & 0.0200 & 0.0003 & $\mathrm{U}$ & $\mathrm{L}$ & 0.0235 & 0.0063 & + & 0.1750 \\
\hline PU239 & 1101 & 03 & $01 / 28 / 2011$ & 11A0279 & 99158 & IPSA & 1414 & 0.0200 & 0.0003 & U & $\mathrm{L}$ & 0.0223 & 0.0059 & + & 0.1150 \\
\hline PU239 & 1102 & 12 & $03 / 04 / 2011$ & 11B0414 & 99150 & IPSA & 1180 & 0.0200 & 0.0003 & U & $\mathrm{L}$ & 0.0254 & 0.0059 & + & 0.2700 \\
\hline \multirow[t]{3}{*}{ PU239 } & 1102 & 13 & $03 / 04 / 2011$ & 11B0415 & 99154 & IPSA & 1265 & 0.0200 & 0.0003 & U & L & 0.0227 & 0.0065 & + & 0.1350 \\
\hline & & & & 14 & $\mathbf{U}$ & \multicolumn{2}{|l|}{$\begin{array}{l}\text { PU239 } \\
\text { Count }\end{array}$} & $\begin{array}{c}0.0200 \\
14\end{array}$ & $\begin{array}{l}\text { Average R } \\
\text { St Dev }\end{array}$ & Result & \multicolumn{2}{|c|}{$\overline{0.0209}$} & & $\begin{array}{c}\text { Mean Rel. Bias } \\
\text { Mean Rel. Precision }\end{array}$ & $\begin{array}{l}0.0464 \\
0.2937\end{array}$ \\
\hline & \multicolumn{3}{|c|}{ Number of total U PU239 } & 17 & & & & & & & & & & & \\
\hline SR & 1005 & 15 & $06 / 03 / 2010$ & 10E0287 & 91382 & IPSA & 1471 & 0.0000 & 0.0000 & $\mathrm{U}$ & $\mathrm{L}$ & 0.8920 & 0.4610 & - & \\
\hline SR & 1005 & 16 & $06 / 04 / 2010$ & 10E0313 & 50575 & IPSA & 785 & 0.0000 & 0.0000 & $\mathrm{U}$ & $\mathrm{L}$ & 0.3310 & 0.4410 & - & \\
\hline \multirow[t]{2}{*}{ SR } & 1005 & 17 & $06 / 11 / 2010$ & 10E0355 & $3 \mathrm{C} 135$ & IPSA & 1164 & 0.0000 & 0.0000 & U & $\mathrm{L}$ & 1.5000 & 0.4430 & + & \\
\hline & & & & 3 & $\mathbf{U}$ & \multicolumn{2}{|l|}{$\begin{array}{c}\mathrm{SR} \\
\text { Count }\end{array}$} & $\begin{array}{c}0.0000 \\
3\end{array}$ & \multicolumn{2}{|c|}{$\begin{array}{l}\text { Average Result } \\
\text { St Dev }\end{array}$} & $\begin{array}{l}0.9077 \\
0.5847\end{array}$ & $\overline{\mathrm{DL}}$ & $\begin{array}{l}1.7072 \\
4.1185\end{array}$ & $\begin{array}{cc}\text { Chem Yield } & 0.71 \\
\text { Det Eff } & 0.38\end{array}$ & Time \\
\hline SR & 1003 & 05 & $04 / 20 / 2010$ & 10D0067 & 99153 & IPSA & 1141 & 10.0000 & 0.1790 & $\mathrm{U}$ & $\mathrm{L}$ & 8.3400 & 1.1900 & + & -0.1660 \\
\hline SR & 1005 & 08 & $07 / 12 / 2010$ & 10F0629 & 31776 & IPSA & 1094 & 10.0000 & 0.1860 & $\mathrm{U}$ & $\mathrm{L}$ & 8.5700 & 1.0600 & + & -0.1430 \\
\hline SR & 1005 & 11 & 07/i2/2010 & 10F0755 & 99156 & IPSA & 1100 & 10.0000 & 0.1860 & $\mathrm{U}$ & $\mathrm{L}$ & 8.4500 & 1.0600 & + & -0.1550 \\
\hline SR & 1005 & 09 & 07/12/2010 & $10 \mathrm{~F} 0656$ & 50807 & IPSA & 1164 & 10.0000 & 0.1860 & $\mathrm{U}$ & $\mathrm{L}$ & 8.0300 & 1.0400 & + & -0.1970 \\
\hline SR & 1008 & 06 & 09/03/2010 & $10 \mathrm{H} 0554$ & 80109 & IPSA & 1245 & 10.0000 & 0.1550 & $\mathrm{U}$ & $\mathrm{L}$ & 9.6100 & 1.2700 & + & -0.0390 \\
\hline SR & 1009 & 17 & $10 / 30 / 2010$ & $10 \mathrm{~J} 2409$ & 99161 & IPSA & 1406 & 10.0000 & 0.1850 & $\mathrm{U}$ & $\mathrm{L}$ & 10.4000 & 1.3500 & + & 0.0400 \\
\hline SR & 1009 & 18 & $11 / 04 / 2010$ & $10 \mathrm{~J} 2666$ & 50809 & IPSA & 1199 & 10.0000 & 0.1850 & $\mathrm{U}$ & $\mathrm{L}$ & 10.7000 & 1.4100 & + & 0.0700 \\
\hline SR & 1011 & 06 & $11 / 24 / 2010$ & $10 \mathrm{~K} 0556$ & 59600 & IPSA & 1284 & 10.0000 & 0.2220 & $\mathrm{U}$ & $\mathrm{L}$ & 9.6200 & 1.2200 & + & -0.0380 \\
\hline SR & 1011 & 07 & $11 / 24 / 2010$ & 10K0557 & 59698 & IPSA & 1102 & 10:0000 & 0.2220 & $\mathrm{U}$ & $\mathrm{L}$ & 10.0000 & 1.2400 & + & \\
\hline SR & 1101 & 04 & $02 / 02 / 2011$ & $11 \mathrm{~A} 0233$ & $3 \mathrm{C} 142$ & IPSA & 1174 & 10.0000 & 0.1200 & U & L & 9.6900 & 1.2000 & + & -0.0310 \\
\hline
\end{tabular}




\begin{tabular}{|c|c|c|c|c|c|c|}
\hline ISO CD & YRMC & SEQ & $\begin{array}{l}\text { ANAL } \\
\text { DATE }\end{array}$ & TAGWORD & PAYID & $\begin{array}{r}\text { REQ } \\
\text { ANAL } \\
\end{array}$ \\
\hline SR & 1101 & 03 & $02 / 02 / 2011$ & $11 \mathrm{~A} 0279$ & 99158 & IPSA \\
\hline SR & 1101 & 02 & $02 / 02 / 2011$ & $11 \mathrm{~A} 0232$ & $3 \mathrm{C} 134$ & IPSA \\
\hline SR & 1102 & 13 & 03/03/2011 & $11 \mathrm{~B} 0415$ & 99154 & IPSA \\
\hline SR & 1102 & 12 & 03/03/2011 & $11 \mathrm{~B} 0414$ & 99150 & IPSA \\
\hline SR & 1102 & 14 & $03 / 29 / 2011$ & $11 \mathrm{C} 0284$ & 59001 & SR \\
\hline SR & 1103 & 09 & 03/30/2011 & $11 \mathrm{C} 0244$ & 32533 & SR \\
\hline
\end{tabular}

VOL SPIKE UNCERT TYPE MR RESULT UNCERT DET

REL BIAS

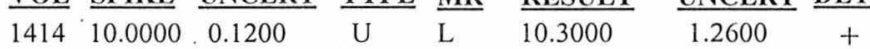

0.0300

$\begin{array}{lllllll}1225 & 10.0000 & 0.1200 & \text { U } & \text { L } & 8.8900 & 1.1200\end{array}$

$-0.1110$

$\begin{array}{lllllll}1265 & 10.0000 & 0.1510 & \text { U } & \text { L } & 8.9000 & 1.2100\end{array}+$

$-0.1100$

$\begin{array}{lllllll}1180 & 10.0000 & 0.1510 & \text { U } & \text { L } & 10.5000 & 1.4000\end{array}+$

0.0500

$\begin{array}{lllllll}1363 & 10.0000 & 0.1510 & \text { U } & \text { L } & 10.4000 & 1.2900\end{array}$

0.0400

$\begin{array}{lllllll}1278 & 10.0000 & 0.0560 & \text { U } & \text { L } & 9.1100 & 1.3000\end{array}+$

$-0.0890$

$$
1 6 U \longdiv { \text { Count } }
$$

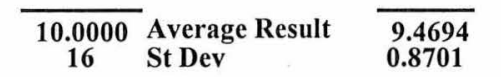

Mean Rel. Bias

Mean Rel. Precision

-0.0531
0.0870

Number of total U SR 19

$\begin{array}{lllllll}\text { U 235 } & 1102 & 08 & 02 / 24 / 2011 & 11 \mathrm{~B} 0183 & \text { AU001 } & \text { IU } \\ \text { U 235 } & 1102 & 09 & 02 / 24 / 2011 & 11 \mathrm{~B} 0186 & \text { AU003 } & \text { IU } \\ \text { U 235 } & 1102 & 11 & 02 / 24 / 2011 & 11 \mathrm{~B} 0185 & \text { AU002 } & \text { IU } \\ \text { U 235 } & 1102 & 10 & 02 / 24 / 2011 & 11 \mathrm{~B} 0269 & \text { AU004 } & \text { IU } \\ \text { U 235 } & 1103 & 06 & 03 / 28 / 2011 & 11 \mathrm{C} 0549 & \text { AU006 } & \text { IU } \\ \text { U 235 } & 1103 & 07 & 03 / 28 / 2011 & 11 \mathrm{C} 0550 & \text { AU007 } & \text { IU } \\ \text { U 235 } & 1103 & 04 & 03 / 28 / 2011 & 11 \mathrm{C} 0547 & \text { AU004 } & \text { IU } \\ \text { U 235 } & 1103 & 03 & 03 / 28 / 2011 & 11 \mathrm{C} 0546 & \text { AU003 } & \text { IU } \\ \text { U 235 } & 1103 & 02 & 03 / 28 / 2011 & 11 \mathrm{C} 0545 & \text { AU002 } & \text { IU } \\ \text { U 235 } & 1011 & 05 & 03 / 28 / 2011 & 11 \mathrm{C} 0543 & \text { AU001 } & \text { IU } \\ \text { U 235 } & 1103 & 08 & 03 / 28 / 2011 & 11 \mathrm{C} 0551 & \text { AU008 } & \text { IU } \\ \text { U 235 } & 1103 & 05 & 03 / 28 / 2011 & 11 \mathrm{C} 0548 & \text { AU005 } & \text { IU }\end{array}$

$\begin{array}{llllllll}979 & 0.0000 & 0.0000 & \mathrm{U} & \mathrm{U} & 0.0010 & 0.0045 & - \\ 978 & 0.0000 & 0.0000 & \mathrm{U} & \mathrm{U} & -0.0019 & 0.0054 & - \\ 980 & 0.0000 & 0.0000 & \mathrm{U} & \mathrm{U} & 0.0027 & 0.0031 & - \\ 977 & 0.0000 & 0.0000 & \mathrm{U} & \mathrm{U} & 0.0012 & 0.0040 & - \\ 980 & 0.0000 & 0.0000 & \mathrm{U} & \mathrm{U} & 0.0053 & 0.0035 & - \\ 980 & 0.0000 & 0.0000 & \mathrm{U} & \mathrm{U} & 0.0025 & 0.0028 & - \\ 977 & 0.0000 & 0.0000 & \mathrm{U} & \mathrm{U} & 0.0027 & 0.0031 & - \\ 977 & 0.0000 & 0.0000 & \mathrm{U} & \mathrm{U} & 0.0023 & 0.0032 & - \\ 1228 & 0.0000 & 0.0000 & \mathrm{U} & \mathrm{U} & 0.0024 & 0.0028 & - \\ 1228 & 0.0000 & 0.0000 & \mathrm{U} & \mathrm{U} & 0.0036 & 0.0047 & - \\ 981 & 0.0000 & 0.0000 & \mathrm{U} & \mathrm{U} & 0.0038 & 0.0037 & - \\ 977 & 0.0000 & 0.0000 & \mathrm{U} & \mathrm{U} & -0.0003 & 0.0040 & -\end{array}$

$12 \mathrm{U}$
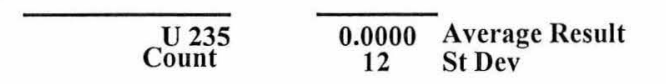

\begin{tabular}{lllllll}
\hline 0.0021 & DL & 0.0034 & Chem Yield & 0.87 & Time & 2520 \\
0.0019 & MDA & 0.0107 & Det Eff & 0.39 & &
\end{tabular}

Number of total U U235 12

$\begin{array}{lllll}\mathrm{U} 238 & 1005 & 14 & 05 / 14 / 2010 & 10 \mathrm{E} 0380\end{array}$

U 238

$1005 \quad 12 \quad 05 / 14 / 2010-10 \mathrm{E} 0356$

$\begin{array}{llll}970 & 0.0000 & 0.0000 \quad U\end{array}$

$\begin{array}{lll}0.0053 & 0.0010+\end{array}$

$\begin{array}{llll}2 & \text { U } & \begin{array}{c}\text { C 238 } \\ \text { Count }\end{array}\end{array}$

$\begin{array}{llll}978 & 0.0000 & 0.0000 \quad \mathrm{U}\end{array}$

$0.0064 \quad 0.0022+$

U 238

$\begin{array}{llllll}1102 & 10 & 02 / 24 / 2011 & 11 B 0269 & \text { AU004 IU }\end{array}$

$\begin{array}{cl}0.0000 & \text { Average Result } \\ \text { St Dev }\end{array}$

\begin{tabular}{lllllll}
\hline 0.0058 & DL & 0.0050 & Chem Yield & 1.00 & Time & 2520 \\
0.0008 & MDA & 0.0510 & Det Eff & 0.39
\end{tabular}

$\begin{array}{llll}977 & 0.1460 & 0.0006 \quad \mathrm{U}\end{array}$

$\begin{array}{llll}\mathrm{U} & 0.1670 \quad 0.0196+\end{array}$

0.1438

U 238

$\begin{array}{llllll}1102 & 08 & 02 / 24 / 2011 & 11 B 0183 & \text { AU001 IU }\end{array}$

$\begin{array}{lllllll}979 & 0.1460 & 0.0006 & \mathrm{U} & \mathrm{U} & 0.1440 & 0.0167\end{array}$

$-0.0137$ 


\begin{tabular}{|c|c|c|c|c|c|c|c|c|c|c|c|c|c|c|c|}
\hline ISO CD & $\underline{\text { YRM }}$ & SEQ & $\begin{array}{l}\text { ANAL } \\
\text { DATE }\end{array}$ & TAGWORD & PAYID & $\begin{array}{r}\text { REQ } \\
\text { ANAL } \\
\end{array}$ & VOL & $\underline{\text { SPIKE }}$ & UNCERT & TYPE & MR & RESULT & UNCERT & $\underline{\text { DET }}$ & REL BIAS \\
\hline $\bar{U} 238$ & 1102 & 11 & $02 / 24 / 2011$ & $11 \mathrm{~B} 0185$ & $\overline{\mathrm{AU} 002}$ & $\mathrm{IU}$ & $\overline{980}$ & $\overline{0.1460}$ & 0.0006 & $\mathrm{U}$ & $\mathrm{U}$ & 0.1530 & 0.0182 & + & 0.0479 \\
\hline U 238 & 1102 & 09 & $02 / 24 / 2011$ & 11B0186 & AU003 & $\mathrm{IU}$ & 978 & 0.1460 & 0.0006 & $\mathrm{U}$ & $\mathrm{U}$ & 0.1360 & 0.0167 & + & -0.0685 \\
\hline U 238 & 1103 & 06 & $03 / 28 / 2011$ & $11 \mathrm{C} 0549$ & AU006 & IU & 980 & 0.1460 & 0.0007 & $\mathrm{U}$ & U & 0.1680 & 0.0193 & + & 0.1507 \\
\hline U 238 & 1103 & 02 & $03 / 28 / 2011$ & $11 \mathrm{C} 0545$ & AU002 & IU & 1228 & 0.1460 & 0.0007 & $\mathrm{U}$ & $\mathrm{U}$ & 0.1570 & 0.0180 & + & 0.0753 \\
\hline U 238 & 1103 & 07 & $03 / 28 / 2011$ & $11 \mathrm{C} 0550$ & AU007 & $\mathrm{IU}$ & 980 & 0.1460 & 0.0007 & $\mathrm{U}$ & $\mathrm{U}$ & 0.1450 & 0.0172 & + & -0.0068 \\
\hline U 238 & 1103 & 05 & 03/28/2011 & $11 \mathrm{C} 0548$ & AU005 & $\mathrm{IU}$ & 977 & 0.1460 & 0.0007 & $\mathrm{U}$ & $\mathrm{U}$ & 0.1500 & 0.0174 & + & 0.0274 \\
\hline U 238 & 1103 & 08 & $03 / 28 / 2011$ & $11 \mathrm{C} 0551$ & AU008 & $\mathrm{IU}$ & 981 & 0.1460 & 0.0007 & $\mathrm{U}$ & $\mathrm{U}$ & 0.1470 & 0.0173 & + & 0.0068 \\
\hline U 238 & 1103 & 03 & $03 / 28 / 2011$ & $11 \mathrm{C} 0546$ & AU003 & $\mathrm{IU}$ & 977 & 0.1460 & 0.0007 & $\mathrm{U}$ & $\mathrm{U}$ & 0.1340 & 0.0161 & + & -0.0822 \\
\hline U 238 & 1011 & 05 & $03 / 28 / 2011$ & $11 \mathrm{C} 0543$ & AU001 & $\mathrm{IU}$ & 1228 & 0.1460 & 0.0017 & $\mathrm{U}$ & $\mathrm{U}$ & 0.1380 & 0.0164 & + & -0.0548 \\
\hline U 238 & 1103 & 04 & $03 / 28 / 2011$ & $11 \mathrm{C} 0547$ & AU004 & IU & 977 & 0.1460 & 0.0007 & $\mathrm{U}$ & $\mathrm{U}$ & 0.1880 & 0.0214 & + & 0.2877 \\
\hline & & & & 12 & $\mathbf{U}$ & $\underset{\text { Count }}{\mathrm{U} 238}$ & & $\begin{array}{c}0.1460 \\
12\end{array}$ & $\begin{array}{l}\text { Average } R \\
\text { St Dev }\end{array}$ & esult & $\begin{array}{l}0.1522 \\
0.0157\end{array}$ & & & $\begin{array}{l}\text { Mean Rel. Bias } \\
\text { Mean Rel. Precision }\end{array}$ & $\begin{array}{l}0.0428 \\
0.1077\end{array}$ \\
\hline U 238 & 1003 & 03 & $04 / 16 / 2010$ & $10 \mathrm{D} 0070$ & $3 \mathrm{G} 522$ & U 238 & 1392 & 0.2000 & 0.0012 & $\mathrm{U}$ & & 0.3400 & 0.0115 & + & 0.7000 \\
\hline U 238 & 1005 & 03 & $05 / 19 / 2010$ & $10 \mathrm{E} 0242$ & SG563 & U 238 & 1157 & 0.2000 & 0.0012 & $\mathrm{U}$ & & 0.1660 & 0.0103 & + & -0.1700 \\
\hline U 238 & 1005 & 04 & $05 / 26 / 2010$ & $10 \mathrm{E} 0729$ & 59783 & U 238 & 1397 & 0.2000 & 0.0012 & $\mathrm{U}$ & & 0.1860 & 0.0087 & + & -0.0700 \\
\hline U 238 & 1005 & 06 & $06 / 14 / 2010$ & $10 \mathrm{~F} 0710$ & 80109 & U 238 & 1163 & 0.2000 & 0.0012 & $\mathrm{U}$ & & 0.1740 & 0.0080 & + & -0.1300 \\
\hline U 238 & 1007 & 03 & $07 / 23 / 2010$ & $10 \mathrm{G} 0290$ & 99158 & U 238 & 1378 & 0.2000 & 0.0023 & $\mathrm{U}$ & & 0.1500 & 0.0237 & + & -0.2500 \\
\hline U 238 & 1005 & 05 & $07 / 27 / 2010$ & 10G0197 & 32514 & U 238 & 1229 & 0.2000 & 0.0012 & $\mathrm{U}$ & & 0.1800 & 0.0153 & + & -0.1000 \\
\hline U 238 & 1005 & 07 & $07 / 27 / 2010$ & $10 \mathrm{G} 0207$ & 32533 & U 238 & 1244 & 0.2000 & 0.0012 & $\mathrm{U}$ & & 0.1640 & 0.0202 & + & -0.1800 \\
\hline U 238 & 1007 & 04 & $08 / 12 / 2010$ & $10 \mathrm{H} 0547$ & 99161 & U 238 & 1318 & 0.2000 & 0.0023 & $\mathrm{U}$ & & 0.1730 & 0.0101 & + & -0.1350 \\
\hline U 238 & 1008 & 04 & $08 / 18 / 2010$ & $10 \mathrm{H} 0565$ & 59600 & U 238 & 1380 & 0.2000 & 0.0013 & $\mathrm{U}$ & & 0.1040 & 0.0124 & + & -0.4800 \\
\hline U 238 & 1008 & 02 & $08 / 18 / 2010$ & $10 \mathrm{H} 0552$ & $3 \mathrm{C} 142$ & U 238 & 1297 & 0.2000 & 0.0013 & $\mathrm{U}$ & & 0.1450 & 0.0059 & + & -0.2750 \\
\hline U 238 & 1008 & 05 & $08 / 19 / 2010$ & $10 \mathrm{H} 0495$ & 32472 & U 238 & 1077 & 0.2000 & 0.0013 & $\mathrm{U}$ & & 0.1590 & 0.0111 & + & -0.2050 \\
\hline U 238 & 1009 & 15 & 09/20/2010 & $10 \mathrm{I0} 268$ & $3 \mathrm{C} 137$ & U 238 & 1274 & 0.2000 & 0.0014 & $\mathrm{U}$ & & 0.2100 & 0.0125 & + & 0.0500 \\
\hline U 238 & 1008 & 03 & $09 / 20 / 2010$ & 1010299 & 99156 & U 238 & 1216 & 0.2000 & 0.0013 & $\mathrm{U}$ & & 0.1900 & 0.0069 & + & -0.0500 \\
\hline U 238 & 1009 & 14 & $09 / 20 / 2010$ & 1010267 & $3 \mathrm{C} 135$ & U 238 & 1224 & 0.2000 & 0.0014 & $\mathrm{U}$ & & 0.1890 & 0.0111 & + & -0.0550 \\
\hline U 238 & 1009 & 16 & $10 / 14 / 2010$ & $10 \mathrm{~J} 2450$ & $3 G 522$ & U 238 & 1096 & 0.2000 & 0.0014 & $\mathrm{U}$ & & 0.3320 & 0.0245 & + & 0.6600 \\
\hline U 238 & 1010 & 03 & $10 / 15 / 2010$ & $10 \mathrm{~J} 2414$ & 80076 & U 238 & 1301 & 0.2000 & 0.0011 & $\mathrm{U}$ & & 0.1880 & 0.0135 & + & -0.0600 \\
\hline U 238 & 1010 & 02 & $10 / 15 / 2010$ & $10 \mathrm{~J} 2356$ & 50784 & U 238 & 1377 & 0.2000 & 0.0011 & $\mathrm{U}$ & & 0.2080 & 0.0127 & + & 0.0400 \\
\hline U 238 & 1011 & 04 & $11 / 15 / 2010$ & $10 \mathrm{~K} 0494$ & 91386 & U 238 & 1126 & 0.2000 & 0.0023 & $\mathrm{U}$ & & 0.1670 & 0.0080 & + & -0.1650 \\
\hline
\end{tabular}




\begin{tabular}{|c|c|c|c|c|c|c|c|c|c|c|c|c|c|c|c|}
\hline ISO CD & $\underline{\mathrm{YRM}}$ & SEQ & $\begin{array}{l}\text { ANAL } \\
\text { DATE }\end{array}$ & TAGWORD & PAYID & $\begin{array}{r}\text { REQ } \\
\text { ANAL }\end{array}$ & VOL & SPIKE & UNCERT & TYPE & MR & RESULT & UNCERT & DET & REL BIAS \\
\hline$\overline{\text { U } 238}$ & 1011 & 03 & $11 / \overline{15 / 2010}$ & $10 \mathrm{~K} 0558$ & 59783 & $\overline{\mathrm{U} 238}$ & $\overline{1377}$ & $\overline{0.2000}$ & 0.0023 & $\mathrm{U}$ & & 0.1720 & 0.0152 & + & -0.1400 \\
\hline U 238 & 1010 & 04 & $11 / 17 / 2010$ & $10 \mathrm{~K} 0547$ & $3 \mathrm{C} 136$ & U 238 & 1119 & 0.2000 & 0.0011 & U & & 0.2090 & 0.0159 & + & 0.0450 \\
\hline U 238 & 1011 & 02 & $11 / 29 / 2010$ & $10 \mathrm{~K} 0296$ & SG563 & U 238 & 1176 & 0.2000 & 0.0023 & U & & 0.2010 & 0.0163 & + & 0.0050 \\
\hline U 238 & 1102 & 04 & $02 / 11 / 2011$ & $11 \mathrm{~B} 0368$ & 99161 & U 238 & 1091 & 0.2000 & 0.0008 & U & & 0.1720 & 0.0097 & + & -0.1400 \\
\hline U 238 & 1102 & 03 & $02 / 11 / 2011$ & $11 \mathrm{~B} 0369$ & $3 \mathrm{C} 142$ & U 238 & 1383 & 0.2000 & 0.0008 & U & & 0.1550 & 0.0165 & + & -0.2250 \\
\hline U 238 & 1102 & 06 & $02 / 11 / 2011$ & 11B0325 & 32472 & U 238 & 1319 & 0.2000 & 0.0008 & U & & 0.1960 & 0.0123 & + & -0.0200 \\
\hline U 238 & 1102 & 02 & $02 / 11 / 2011$ & 11B0384 & 59600 & U 238 & 1204 & 0.2000 & 0.0010 & U & & 0.1900 & 0.0115 & + & -0.0500 \\
\hline U 238 & 1102 & 05 & $02 / 28 / 2011$ & $11 \mathrm{~B} 0270$ & 99216 & U 238 & 1276 & 0.2000 & 0.0008 & $\mathrm{U}$ & & 0.1800 & 0.0118 & + & -0.1000 \\
\hline \multirow[t]{5}{*}{ U 238} & 1102 & 07 & $03 / 16 / 2011$ & $11 \mathrm{C} 0326$ & 99156 & U 238 & 1442 & 0.2000 & 0.0008 & $\mathrm{U}$ & & 0.2140 & 0.0134 & + & 0.0700 \\
\hline & & & & 27 & $\mathbf{U}$ & & & $\begin{array}{c}0.2000 \\
27\end{array}$ & $\begin{array}{l}\text { Average R } \\
\text { St Dev }\end{array}$ & esult & $\begin{array}{l}0.1894 \\
0.0484\end{array}$ & & & $\begin{array}{l}\text { Mean Rel. Bias } \\
\text { Mean Rel. Precision }\end{array}$ & $\begin{array}{r}-0.0530 \\
0.2419\end{array}$ \\
\hline & \multirow{3}{*}{\multicolumn{3}{|c|}{ Number of total U U 238}} & 41 & & & & & & & & & & & \\
\hline & & & & & & & & & & & & & & Total Samples & 86 \\
\hline & & & & & & & & & & & & & & Total Results & 170 \\
\hline
\end{tabular}


APPENDIX B

GEL QUALITY CONTROL SAMPLE REPORT SUMMARY

(Historical File Only) 


\section{PNNL \\ QUARTERLY \\ QC PACKAGE}

Annual 2010

April 1, 2010 - March 31, 2011 


\section{Package Quality Control Package:}

All data was packaged, reviewed, and found acceptable by the following packager:

Signature:

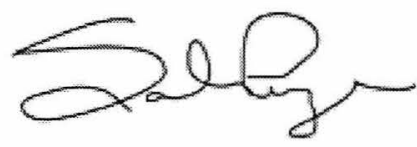

Date: 11-JUN-2012
Name: Salina Pizarro

Title: Analyst I 


\section{Review Quality Control Package:}

All data was reviewed and found acceptable by the following Reviewer:

Signature:

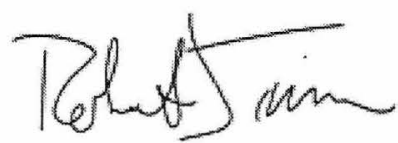

Date: 11-JUN-2012
Name: Robert Timm

Title: Group Leader 


\section{Table of Contents}

Section 1: Case Narrative

Section 2: Database Results

Urine Data

Am-241 - Blank Activity/Tracer Yield for Am-241 and Cm

Am-241 - Graph for Blank Activity/Tracer Yield for Am-241 and Cm

Am-241 - LCS Bias High

Am-241 - Graph for LCS Bias High

Am-241 - LCS Bias Low

Am-241 - Graph for LCS Bias Low

Cm-242 - Blank Activity/Tracer Yield (Included for Cm-only samples)

Cm-242 - Graph for Blank Activity/Tracer Yield (Included for Cm-only samples)

Cm-243/244 - Blank Activity

Cm-243/244 - Graph for Blank Activity

Cm-243/244 - LCS Bias High

Cm-243/244 - Graph for LCS Bias High

Cm-243/244 - LCS Bias Low

Cm-243/244 - Graph for LCS Bias Low

Am-243 - Blank Activity/ Tracer Yield

Am-243 - Graph for Blank Activity/ Tracer Yield

Am-243 - LCS Bias High

Am-243 - Graph for LCS Bias High

Am-243 - LCS Bias Low

Am-243 - Graph for LCS Bias Low

Np-237 - Blank Activity/Tracer Yield

Np-237 - Graph for Blank Activity/Tracer Yield

Np-237 - LCS Bias High

Np-237 - Graph for LCS Bias High

Np-237 -LCS Bias Low

Np-237 - Graph for LCS Bias Low

Pu-238 - Blank Activity

Pu-238 - Graph for Blank Activity

Pu-239/240 - Blank Activity/ Tracer Yield

$\mathrm{Pu}-239 / 240$ - Graph for Blank Activity/ Tracer Yield

Pu-239/240 - LCS Bias High

Pu-239/240 - Graph for LCS Bias High

Pu-239/240 - LCS Bias Low

$\mathrm{Pu}-239 / 240$ - Graph for LCS Bias Low 


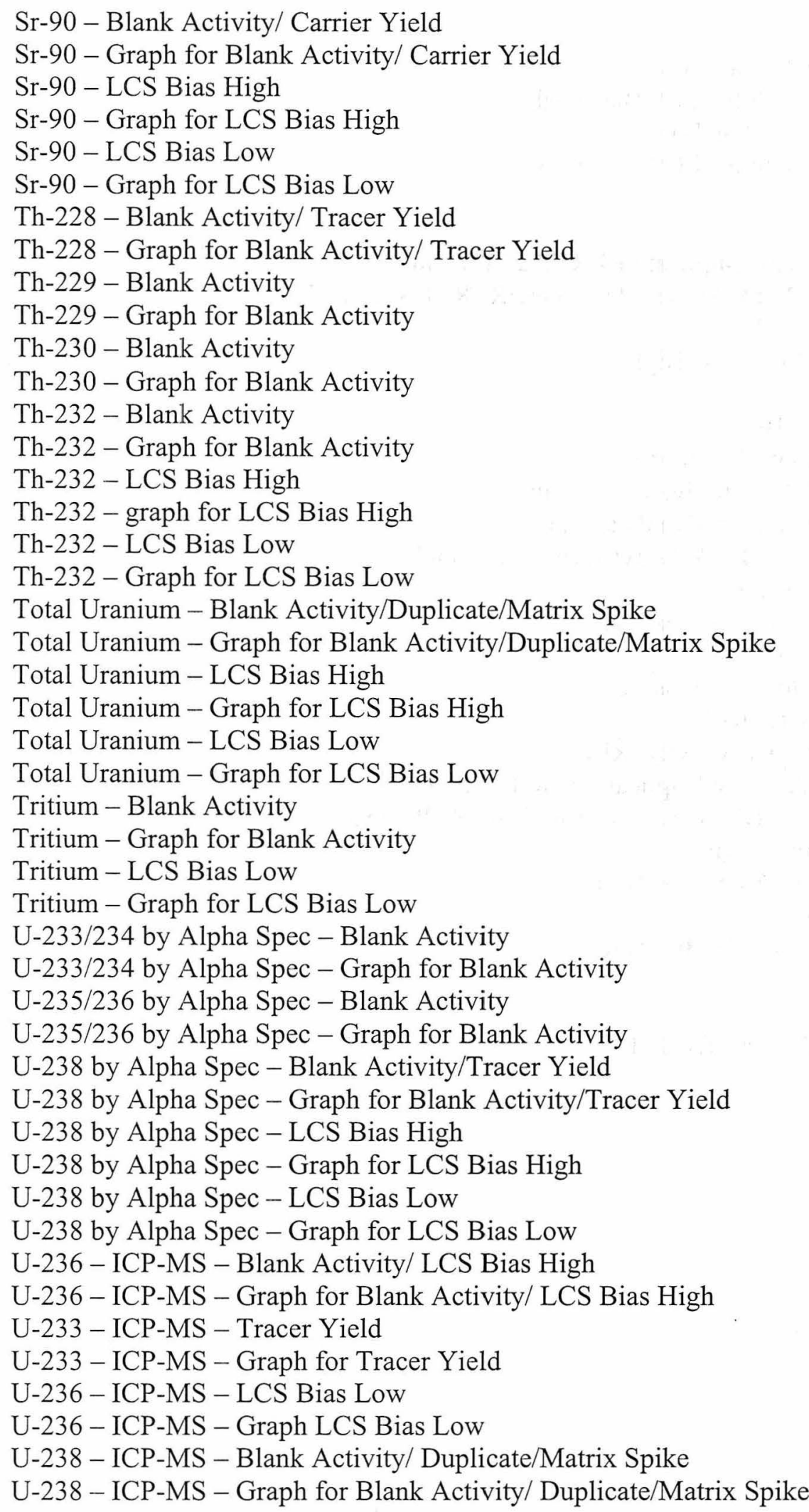


U-238 - ICP-MS -LCS Bias High

U-238 - ICP-MS - Graph for LCS Bias High

U-238 - ICP-MS - LCS Bias Low

U-238 - ICP-MS - Graph for LCS Bias Low

Fecal Data

Am-241 - Blank Activity/Duplicate/RER/ Tracer Yield

Am-241 - Graph for Blank Activity/Duplicate/RER/ Tracer Yield

Am-241 - LCS Bias High

Am-241 - Graph for LCS Bias High

Am-241 - LCS Bias Low

Am-241 - Graph LCS Bias Low

Cm-242 - Blank Activity/Duplicate

Cm-242 - graph for Blank Activity/Duplicate

Cm-243/244 - Blank Activity/Duplicate/Yield

Cm-243/244 - graph for Blank Activity/Duplicate/Yield

Cm-243/244 -LCS bias high

Cm-243/244 - graph for LCS bias high

Cm-243/244 -LCS bias Low

Cm-243/244 - graph for LCS bias Low

Pu-238 - Blank Activity/ RER

Pu-238 - Graph for Blank Activity/ RER

Pu-239/240 - Blank Activity/Duplicate/RER/Tracer Yield

Pu-239/240 - Graph for Blank Activity/Duplicate/RER/Tracer Yield

Pu-239/240 - LCS Bias High

Pu-239/240 - Graph for LCS Bias High

Pu-239/240 - LCS Bias Low

Pu-239/240 - Graph for LCS Bias Low

Section 3: DOELAP/NRIP RESULTS 


\begin{tabular}{|ll|}
\hline & \multicolumn{1}{|c|}{ Legend } \\
\# & $=$ the N-value (number of the samples in the data set) \\
Samp ID & $=$ GEL laboratory sample identification number \\
Inst & $=$ the analytical instrument identification number/name \\
Run Date & $=$ the sample analysis date \\
LCL & $=$ Lower Control Level (minus 3 sigma) \\
LWL & $=$ Lower Warning Level (minus 2 sigma) \\
Mean & $=$ the average value of the data set \\
Numvalue & $=$ Number Value for parameter being monitored \\
Exclude & $=$ a checked box indicates the data was not used in the calculation of the \\
& mean and control limits \\
Stdev & $=$ Standard Deviation \\
UWL & $=$ Upper Warning Level (plus 2 sigma) \\
UCL & $=$ Upper Contol Level (plus 3 sigma) \\
Dispersion & $=$ the difference of the individual relative bias from the mean \\
Parent Sample & $=$ the sample that was duplicated \\
TPU & $=$ Total Proportion Uncertainty (1 sigma combined standard uncertainty) \\
RER & $=$ Relative Error Ratio (the difference of the individual duplicate pairs \\
& based on the combined standard uncertainties of the individual analyses) \\
Nominal & $=$ the calculated concentration of the spike in the sample geometry \\
Result & $=$ the actual measured analyte concentration in the sample \\
Bias & $=$ the deviation of a measured value from the expected value
\end{tabular}


Zone Definitions

\section{Statistical Parameters Utilized by The GEL Group, Inc}

Zone A - Area defined as being between 2 and 3 times sigma above the center line

Zone B - Area defined as being between 1 and 2 times sigma above the center line

Zone $\mathrm{C}-$ Area defined as being between the center line and 1 times sigma

\section{Data Flag Definitions}

1. Nine (9) points on Zone $\mathrm{C}$ and beyond on one side of the central line - Indicates that the process average may have changed

2. Six (6) points in a row steadily increasing or decreasing on one side of the central line - Indicates that a drift may be occurring in the process average

3. Fourteen (14) points in a row alternating up or down on either side of the center line - If this test is positive it indicates that two systematically alternating causes may be producing different results

4. Two (2) out of three (3) points in a row are in Zone A or beyond - Indicates an early warning of a process shift

5. Four (4) out of five (5) points are in Zone B or beyond - If positive, this, like flag 4, indicates and early warning of a potential process shift

6. Fifteen (15) points are in Zone $\mathrm{C}$ above or below the center line - Indicates a smaller variability than expected

7. Eight (8) points in a row are in Zone B, A or beyond on either side of the center line with no points occurring in Zone $\mathrm{C}$ - Indicates that different samples are affected by different factors resulting in bimodal distribution of averages

\section{References}

Statistical Software - Data Mining, Statistical Analysis and Quality Control

Quality Control Charts - www.statsoft.com/textbook/stquacon.html 


\section{SECTION 1}

CASE NARRATIVE

Page 5 of 13 


\section{Annual - QC Report Operational Year 2010}

This report summarizes Quality Control Samples (QC) analyzed with bioassay samples under Contract 112512 during the Contract Year 2010, beginning April 1, 2010 and ending March 31, 2011. Included in the report are listings for the blank, duplicate and spike results. A description of the attached data is provided below. Ten thousand six hundred and ninety-six reported samples were analyzed under this contract with a run date during the annual year. The QC samples include blanks, spikes, and duplicates.

\section{PNNL Sample/QC Summary}

Annual 2010 QC Summary Table

\begin{tabular}{|c|c|c|c|c|c|}
\hline & Matrix & Reported Samples & QC Samples & Total Samples & $\%$ QC \\
\hline Americium-Curium & FECAL & 100 & 160 & 260 & 62 \\
\hline Plutonium & FECAL & 95 & 155 & 250 & 62 \\
\hline Americium-Curium & URINE & 1969 & 845 & 2814 & 30 \\
\hline Americium-243 & URINE & 27 & 42 & 69 & 61 \\
\hline Neptunium & URINE & 7 & 15 & 22 & 68 \\
\hline Tritium & URINE & 234 & 148 & 382 & 39 \\
\hline Thorium & URINE & 17 & 36 & 53 & 68 \\
\hline Plutonium & URINE & 4320 & 1669 & 5989 & 28 \\
\hline Strontium 90 & URINE & 1519 & 653 & 2172 & 30 \\
\hline Uranium & URINE & 440 & 267 & 707 & 38 \\
\hline Uranium-236 (ICPMS) & URINE & 9 & 24 & 33 & 73 \\
\hline Uranium-238 (ICPMS) & URINE & 1959 & 750 & 2709 & 28 \\
\hline Total & & 10696 & 4764 & 15460 & 31 \\
\hline
\end{tabular}




\section{Laboratory Control Samples (LCS)}

The enclosed listing contains the analysis isotope, matrix, average relative bias and the relative precision statistic. One or more LCS sample was analyzed with each batch of samples

\begin{tabular}{||c|c|c|c|c|c|c||}
\hline \multicolumn{1}{|c|}{ Test } & Matrix & $\begin{array}{c}\text { Number } \\
\text { In Set } \\
\text { (N\#) }\end{array}$ & $\begin{array}{c}\text { Range } \\
\text { High }\end{array}$ & $\begin{array}{c}\text { Average } \\
\text { Nominal } \\
\text { (dpm/sample) }\end{array}$ & $\begin{array}{c}\text { Average } \\
\text { Relative } \\
\text { Bias }\end{array}$ & $\begin{array}{c}\text { Relative } \\
\text { Precision }\end{array}$ \\
\hline \hline Americium-241 & FECAL & 43 & High & 5.43 & -0.0479 & 0.0728 \\
\hline Curium-243/244 & FECAL & 2 & High & 2.55 & -0.0335 & 0.0191 \\
\hline \hline Plutonium-239/240 & FECAL & 42 & High & 5.39 & 0.0051 & 0.0645 \\
\hline \hline Americium-241 & URINE & 281 & High & 0.568 & -0.0812 & 0.0811 \\
\hline \hline Americium-243 & URINE & 14 & High & 0.455 & 0.00921 & 0.0993 \\
\hline \hline Curium-243/244 & URINE & 68 & High & 0.489 & -0.0951 & 0.0191 \\
\hline \hline Neptunium-237 & URINE & 5 & High & 0.395 & 0.0183 & 0.0922 \\
\hline \hline Plutonium-239/240 & URINE & 557 & High & 0.428 & -0.0228 & 0.0891 \\
\hline \hline Thorium-232 & URINE & 12 & High & 2.15 & -0.0055 & 0.0705 \\
\hline \hline Total Uranium & URINE & 37 & High & $1.00 \mathrm{ug} / \mathrm{sample}$ & 0.0072 & 0.0564 \\
\hline \hline Uranium-238 & URINE & 89 & High & 0.381 & 0.0334 & 0.1117 \\
\hline Uranium-236 (ICPMS) & URINE & 8 & High & $5760 \mathrm{pg} / \mathrm{sample}$ & -0.031 & 0.0501 \\
\hline Uranium-238 (ICPMS) & URINE & 113 & High & $0.9926 \mathrm{ug} / \mathrm{sample}$ & -0.0139 & 0.0669 \\
\hline \hline Strontium-90 & URINE & 218 & High & 48.3 & 0.0257 & 0.0941 \\
\hline
\end{tabular}

HA bias for Combined dias $238 \mathrm{u}$ by $(0.0072)(37) *(-0.0130)(113)$

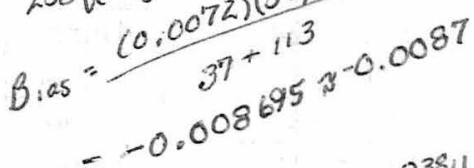

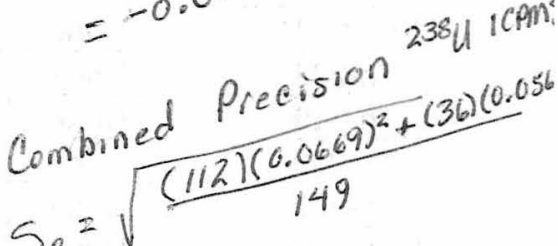
$S_{B}=\sqrt{149}$

*Unless otherwise noted.

$$
=0.0643
$$

\begin{tabular}{|c|c|c|c|c|c|c|c|}
\hline Test & Matrix & $\begin{array}{c}\text { Number } \\
\text { In Set } \\
(\mathrm{N} \#)\end{array}$ & $\begin{array}{c}\text { Range } \\
\text { Low }\end{array}$ & $\begin{array}{c}\text { Average } \\
\text { Nominal } \\
(\mathrm{dpm} / \mathrm{sample})^{*}\end{array}$ & $\begin{array}{l}\text { Number } \\
\text { Below Lc }\end{array}$ & \begin{tabular}{|c} 
Average \\
Relative \\
Bias
\end{tabular} & $\begin{array}{c}\text { Relative } \\
\text { Precision }\end{array}$ \\
\hline Americium-241 & FECAL & 43 & Low & 0.285 & 0 & 0.0375 & 0.2088 \\
\hline Curium-243/244 & FECAL & 2 & Low & 0.115 & 0 & -0.0363 & 0.1853 \\
\hline Plutonium-239/240 & FECAL & 42 & Low & 0.212 & 0 & -0.0132 & 0.2113 \\
\hline Americium-241 & URINE & 280 & Low & 0.0211 & 3 & 0.0148 & 0.286 \\
\hline Americium-243 & URINE & 14 & Low & 0.0192 & 0 & 0.0866 & 0.568 \\
\hline Curium-243/244 & URINE & 69 & Low & 0.023 & 0 & 0.143 & 0.268 \\
\hline Neptunium-237 & URINE & 5 & Low & 0.0217 & 0 & 0.19 & 0.297 \\
\hline Plutonium-239/240 & URINE & 555 & Low & 0.0217 & 2 & 0.0438 & 0.301 \\
\hline Thorium-232 & URINE & 12 & Low & 0.109 & 1 & -0.0324 & 0.3097 \\
\hline Total Uranium & URINE & 37 & Low & $0.05 \mathrm{ug} / \mathrm{sample}$ & 0 & 0.1861 & 0.1544 \\
\hline Uranium-238 & URINE & 89 & Low & 0.0203 & 2 & 0.0641 & 0.3322 \\
\hline Uranium-236 (ICPMS) & URINE & 8 & Low & $564.0301 \mathrm{pg} /$ sample & 0 & -0.109 & 0.3431 \\
\hline Uranium-238 (ICPMS) & URINE & 113 & Low & $0.0496 \mathrm{ug} / \mathrm{sample}$ & 0 & 0.0618 & 0.1816 \\
\hline Strontium-90 & URINE & 217 & Low & 9.8 & 0 & 0.1214 & 0.1824 \\
\hline Tritium & URINE & 74 & Low & $5.35 \mathrm{pCi} / \mathrm{mL}$ & 0 & -0.0054 & 0.0801 \\
\hline
\end{tabular}

Combined Bias and Precision for 2380 by $10 \mathrm{Pm}$

$$
\begin{aligned}
& \text { A } \\
& B_{i a s}=\frac{(0.1861)(37)+(0.0618)(113)}{37+113}=0.0925 \\
& \text { Precision }=\sqrt{\frac{(36)(0.1544)^{2}+(112)(0.1816)^{2}}{149}}=0.175
\end{aligned}
$$




\section{Blanks}

The following table contains the analyses, isotope, matrix, and the calculated MDAs. The alpha spectrometry MDAs are based on the average blank counts and average tracer yields for the quarter. The Strontium MDAs are adjusted according to the average tracer yield for the quarter. The Uranium by ICP-MS MDAs are based on the standard deviation of a standard analyzed each day when samples are analyzed throughout the quarter.

PNNL

Annual 2010

\begin{tabular}{|c|c|c|c|c|c|c|c|c|c|}
\hline & & & & & Avg. & Sample & Detector & Count & \\
\hline Isotope & Matrix & $\mathrm{N \#}$ & MDA & Lc & Volume & units & Yield & Efficiency & $\begin{array}{l}\text { Time } \\
(\mathrm{min})\end{array}$ \\
\hline Am-241 & Urine & 281 & 0.018 & 0.00926 & 1 & $\mathrm{dpm} / \mathrm{s}$ & 0.869 & 0.391 & 2520 \\
\hline Am-243 & Urine & 14 & 0.021 & 0.01139 & 1 & $\mathrm{dpm} / \mathrm{s}$ & 0.867 & 0.391 & 2520 \\
\hline $\mathrm{Cm}-242$ & Urine & 71 & 0.009 & 0.00375 & 1 & $\mathrm{dpm} / \mathrm{s}$ & 0.869 & 0.391 & 2520 \\
\hline $\mathrm{Cm}-243 / 244$ & Urine & 71 & 0.010 & 0.00419 & 1 & $\mathrm{dpm} / \mathrm{s}$ & 0.869 & 0.391 & 2520 \\
\hline $\mathrm{Np}-237$ & Urine & 5 & 0.031 & 0.01852 & 1 & $\mathrm{dpm} / \mathrm{s}$ & 0.6484 & 0.391 & 2520 \\
\hline Pu-238 & Urine & 557 & 0.012 & 0.00530 & 1 & $\mathrm{dpm} / \mathrm{s}$ & 0.76 & 0.391 & 2520 \\
\hline $\mathrm{Pu}-239 / 240$ & Urine & 557 & 0.017 & 0.00809 & 1 & $\mathrm{dpm} / \mathrm{s}$ & 0.76 & 0.391 & 2520 \\
\hline Th-228 & Urine & 12 & 0.071 & 0.05392 & 1 & $\mathrm{dpm} / \mathrm{s}$ & 0.765 & 0.386 & 2520 \\
\hline Th-229 & Urine & 12 & 0.038 & 0.02569 & 1 & $\mathrm{dpm} / \mathrm{s}$ & 0.765 & 0.386 & 2520 \\
\hline Th-230 & Urine & 12 & 0.051 & 0.03515 & 1 & $\mathrm{dpm} / \mathrm{s}$ & 0.765 & 0.386 & 2520 \\
\hline Th-232 & Urine & 12 & 0.031 & 0.01958 & 1 & $\mathrm{dpm} / \mathrm{s}$ & 0.765 & 0.386 & 2520 \\
\hline U-233/234 & Urine & 89 & 0.032 & 0.01772 & 1 & $\mathrm{dpm} / \mathrm{s}$ & 0.801 & 0.386 & 2520 \\
\hline$U-235 / 236$ & Urine & 89 & 0.018 & 0.00866 & 1 & $\mathrm{dpm} / \mathrm{s}$ & 0.801 & 0.386 & 2520 \\
\hline U-238 & Urine & 89 & 0.031 & 0.01737 & 1 & $\mathrm{dpm} / \mathrm{s}$ & 0.801 & 0.386 & 2520 \\
\hline Sr-90 & Urine & 218 & 4.650 & 0.72917 & 1 & $\mathrm{dpm} / \mathrm{s}$ & 0.707 & 0.379 & 45 \\
\hline Tritium & Urine & 74 & 0.808 & 0.50502 & $0.01 \mathrm{~L}$ & $\mathrm{dpm} / \mathrm{L}$ & $\mathrm{n} / \mathrm{a}$ & 0.243 & 20 \\
\hline U-236 (ICPMS) & Urine & 8 & 36.408 & 1.2575 & 0.5 & $\mathrm{pg} / \mathrm{s}$ & 0.870 & $\mathrm{n} / \mathrm{a}$ & $\mathrm{n} / \mathrm{a}$ \\
\hline U-238 (ICPMS) $)^{\star \wedge}$ & Urine & 150 & 0.021 & 0.0062 & $0.001 \mathrm{~L}$ & $\mathrm{ug} / \mathrm{s}$ & $\mathrm{n} / \mathrm{a}$ & $\mathrm{n} / \mathrm{a}$ & $\mathrm{n} / \mathrm{a}$ \\
\hline Am-241 & Fecal & 43 & 0.105 & 0.04276 & 0.3333 & $\mathrm{dpm} / \mathrm{s}$ & 0.864 & 0.391 & 960 \\
\hline $\mathrm{Cm}-242$ & Fecal & 2 & 0.043 & 0.00689 & 0.3333 & $\mathrm{dpm} / \mathrm{s}$ & 0.864 & 0.391 & 960 \\
\hline $\mathrm{Cm}-243 / 244$ & Fecal & 2 & 0.048 & 0.00999 & 0.3333 & $\mathrm{dpm} / \mathrm{s}$ & 0.864 & 0.391 & 960 \\
\hline Pu-238 & Fecal & 42 & 0.060 & 0.01582 & 0.3333 & $\mathrm{dpm} / \mathrm{s}$ & 0.827 & 0.391 & 960 \\
\hline Pu-239/240 & Fecal & 42 & 0.096 & 0.03562 & 0.3333 & $\mathrm{dpm} / \mathrm{s}$ & 0.827 & 0.391 & 960 \\
\hline
\end{tabular}

*U-238 (ICPMS) MDA uses a 2:15 dilution factor.

$\wedge$ U-238 (ICPMS) contains both U-238 by ICPMS

and Total Uranium data, by 1 CPMS et

All analytical batches were analyzed with either a reagent blank, matrix blank or both. Blanks are in control when the calculated MDA and blank activity are both less than CRDL (contract required detection limit). In addition, the chemical tracer yields are evaluated against the yield requirements stated in the subject contract. For U238 (ICP-MS) analysis and Tritium analysis, a yield monitor is not available and minimal chemistry is performed. Therefore a yield monitor is not used, and the yield is assumed to be $1(100 \%)$. Overall, the blank data for each analytical process demonstrate the analyses were in control. Processing categories and samples which did not meet contractual requirements are discussed in the Observations section of this report. 
*Unless otherwise noted.

Overall, the LCS data demonstrates the analytical processes were in control. Any LCS outside the limits is discussed in the Observations section of this report.

\section{Duplicate Samples (DUP)}

The duplicate samples were evaluated to determine that the aliquot procedure produces results within the RER limits of 0 to 3 .

\begin{tabular}{|c|c|c|c|c|c|c|c|c|c|}
\hline \multicolumn{10}{|c|}{ Americium-241 } \\
\hline$\#$ & Sample ID & Inst & Run Date & \begin{tabular}{|c|} 
Tracer \\
Yield \\
\end{tabular} & RER & TPU & $\begin{array}{l}\text { Parent } \\
\text { Sample }\end{array}$ & Result & TPU \\
\hline 1 & 1202250865 & 1726 & 05-NOV-10 & 0.703 & 0.828 & 0.0277 . & 265727001 & 0.0497 and 0.0217 & 0.0277 and 0.0194 \\
\hline 2 & 1202251487 & 1707 & 09-NOV-10 & 0.821 & 0.477 & 0.0156 & 265781001 & 0.0156 and -0.00813 & 0.0156 and 0.0472 \\
\hline 3 & 1202257351 & 1721 & $15-\mathrm{NOV}-10$ & 0.851 & 0.0495 & 0.0151 & 266510001 & -0.00463 and -0.00349 & 0.0151 and 0.0174 \\
\hline 4 & 1202292553 & 1687 & $31-\mathrm{DEC}-10$ & 0.823 & 0.249 & 0.0764 & 269159001 & -0.000765 and 0.0187 & 0.0764 and 0.0172 \\
\hline 5 & 1202295770 & 1630 & 08-JAN-11 & 0.961 & 0.11 & 0.0963 & 269414001 & -0.00404 and -0.0169 & 0.0963 and 0.0669 \\
\hline 6 & 1202301857 & 1644 & 31-JAN-11 & 0.795 & 0.65 & 0.0186 & 270160001 & 0.017 and -0.0246 & 0.0186 and 0.0612 \\
\hline 7 & 1202307613 & 1707 & 22-JAN-11 & 0.918 & 0.158 & 0.0159 & 270577001 & 0.0137 and 0.0101 & 0.0159 and 0.0163 \\
\hline 8 & 1202314736 & 1647 & $05-F E B-11$ & 0.872 & 0.0706 & 0.122 & 271226001 & -.00399 and -.0147 & 0.122 and 0.0903 \\
\hline 9 & 1202319478 & 1659 & 10-FEB-11 & 0.956 & 0.0626 & 0.0952 & 271557001 & -0.00195 and 0.00764 & 0.0952 and 0.12 \\
\hline 10 & 1202321667 & 1671 & 14-FEB-11 & 0.973 & 0.225 & 0.0464 & & -0.0246 and 0. & 0.0464 and 0.124 \\
\hline 11 & 1202324645 & 1692 & 18-FEB-11 & 0.856 & 0.247 & 0.331 & 272001001 & 1.6 and 1.72 & 0.331 and 0.356 \\
\hline 12 & 1202329005 & 1623 & $25-F E B-11$ & 0.79 & 0.627 & 1.11 & 272391001 & 5.67 and 4.76 & 1.11 and 0.935 \\
\hline 13 & 1202333377 & 1670 & 02-MAR-11 & 0.881 & 0.767 & 0.0256 & 272666001 & 0.0521 and 0.0277 & 0.0256 and 0.0189 \\
\hline 14 & 1202336456 & 1625 & 08-MAR-11 & 0.729 & 0.147 & 0.0367 & 272893001 & -0.0115 and -0.00173 & 0.0367 and 0.0554 \\
\hline 15 & 1202345364 & 1623 & 19-MAR-11 & 0.694 & 0.877 & 0.0151 & 273714001 & 0.0226 and 0.0483 & 0.0151 and 0.0251 \\
\hline 16 & 1202353302 & 1641 & 29-MAR-11 & 0.829 & 0.426 & 0.0284 & 274310001 & -0.0316 and 0.00431 & 0.0284 and 0.0793 \\
\hline 17 & 1202119811 & 1636 & 26-MAY-10 & 0.777 & 2.08 & 00.0114 & 253072001 & 0.0216 and -0.00295 & 0.0114 and 0.00298 \\
\hline 18 & 1202150092 & 1628 & 07-JUL-10 & 0.82 & 0.528 & 0.0233 & 255420001 & -0.00296 and 0.0109 & 0.0233 and 0.0121 \\
\hline 19 & 1202151892 & 1715 & 07-JUL-10 & 0.863 & 0.498 & 0.0331 & 255478001 & 0.00158 and -0.0164 & 0.0331 and 0.0145 \\
\hline 20 & 1202155654 & 1629 & 13-JUL-10 & 0.62 & 0.866 & 0.0897 & 255826001 & 0.322 and 0.227 & 0.0897 and 0.0631 \\
\hline 21 & 1202158199 & 1719 & 16-JUL-10 & 0.892 & 0.347 & 0.0103 & 256048001 & 0.0119 and 0.017 & 0.0103 and 0.0105 \\
\hline 22 & 1202162244 & 1714 & 22-JUL-10 & 0.857 & 1.56 & 0.0172 & 256414001 & 0.0318 and 0.00347 & 0.0172 and 0.00589 \\
\hline 23 & 1202168048 & 1722 & $30-\pi U L-10$ & 0.79 & 1.51 & 0.012 & 256841001 & 0.0148 and 0.0554 & 0.012 and 0.024 \\
\hline 24 & 1202173014 & 1635 & 05-AUG-10 & 0.997 & 0.207 & 0.0109 & 257280001 & 0.0134 and 0.0104 & 0.0109 and 0.00954 \\
\hline 25 & 1202201073 & 1720 & $01-S E P-10$ & 0.765 & 0.489 & 0.00805 & 259686001 & 0.00396 and -0.00649 & 0.00805 and 0.0198 \\
\hline 26 & 1202204061 & 1702 & 08 -SEP-10 & 0.698 & 0.542 & 0.165 & 259834001 & 0.717 and 0.853 & 0.165 and 0.189 \\
\hline 27 & 1202213425 & 1688 & 21-SEP-10 & 0.916 & 0.125 & 0.0546 & 260573001 & 0.193 and 0.203 & 0.0546 and 0.0582 \\
\hline 28 & 1202215029 & 1714 & 21-SEP-10 & 0.827 & 0.549 & 0.0434 & 260690001 & 0.132 and 0.101 & 0.0434 and 0.0361 \\
\hline 29 & 1202218896 & 1701 & 27-SEP-10 & 0.782 & 0.304 & 0.00975 & 261055001 & 0.00408 and 0.00869 & 0.00975 and 0.0116 \\
\hline 30 & 1202247800 & 1643 & 04-NOV-10 & 0.774 & 01.5 & 0.0201 & 265418001 & -0.0222 and 0.0157 & 0.0201 and 0.0154 \\
\hline
\end{tabular}




\begin{tabular}{|c|c|c|c|c|c|c|c|c|c|}
\hline \multicolumn{10}{|c|}{ Plutonium-238 } \\
\hline \# & Sample ID & Inst & Run Date & \begin{tabular}{|c} 
Tracer \\
Yield
\end{tabular} & RER & TPU & $\begin{array}{l}\text { Parent } \\
\text { Sample }\end{array}$ & Result & TPU \\
\hline 1 & 1202292563 & 1692 & 31-DEC-10 & 0.91 & 1.78 & 0.0026 & 269159001 & -0.00678 and 0 & 0.0026 and 0.00277 \\
\hline 2 & 1202295774 & 1623 & 08-JAN-11 & 0.959 & 1.1 & 0.0103 & 269414001 & 0.0173 and 0.00515 & 0.0103 and 0.00386 \\
\hline 3 & 1202301861 & 1655 & 31-JAN-11 & 0.91 & 0.622 & 0.0121 & 270160001 & 0.0176 and 0.00857 & 0.0121 and 0.00801 \\
\hline 4 & 1202307617 & 1714 & 22-JAN-11 & 0.851 & 1.71 & 0.00674 & 270577001 & 0.00891 and -0.00331 & 0.00674 and 0.00237 \\
\hline 5 & 1202314740 & 1652 & $05-\mathrm{FEB}-11$ & 0.906 & 0.652 & 0.0111 & 271226001 & 0 and 0.00911 & 0.0111 and 0.00848 \\
\hline 6 & 1202319482 & 1664 & 10-FEB-11 & 0.976 & 0.256 & 0.0144 & 271557001 & 0.00454 and 0 & 0.0144 and 0.0104 \\
\hline 7 & 1202321671 & 1676 & 14-FEB-11 & 0.899 & 1.08 & 0.0175 & 271775001 & -0.00177 and 0.0251 & 0.0175 and 0.0177 \\
\hline 8 & 1202324649 & 1685 & 18-FEB-11 & 0.861 & 0.951 & 0.0937 & 272003001 & 0.694 and 0.796 & 0.0937 and 0.0998 \\
\hline 9 & 1202329009 & 1629 & $25-\mathrm{FEB}-11$ & 1.05 & 0.138 & 0.0816 & 272391001 & 0.629 and 0.613 & 0.0816 and 0.0818 \\
\hline 10 & 1202333387 & 1675 & 02-MAR-11 & 0.878 & 0.577 & 0.0253 & 272666001 & 0.00735 and -0.00947 & 0.0253 and 0.0145 \\
\hline 11 & 1202336464 & 1713 & 08-MAR-11 & 00.763 & 0.299 & 0.0244 & 272893001 & -0.00108 and -0.00954 & 0.0244 and 0.0144 \\
\hline 12 & 1202345368 & 1629 & 19-MAR-11 & 00.597 & 0.728 & 0.0169 & 273714001 & -0.0107 and 0.0108 & 0.0169 and 0.0242 \\
\hline 13 & 1202353306 & 1646 & 29-MAR-11 & 0.81 & 0.44 & 0.0194 & 274310001 & -0.0153 and -0.00399 & 0.0194 and 0.0169 \\
\hline 14 & 1202251491 & 1713 & 09-NOV-10 & 0.819 & 0 & 0.00342 & 265781001 & 0 and 0 & 0.00342 and 0.00363 \\
\hline 15 & 1202257355 & 1726 & 15-NOV-10 & 0.756 & 0.439 & 0.00594 & 266510001 & -0.00115 and -0.00459 & 0.00594 and 0.00512 \\
\hline 16 & 1202119815 & 1641 & 26-MAY-10 & 0.475 & 0.507 & 0.0134 & 253072001 & 0.0148 and 0.0261 & 0.0134 and 0.0178 \\
\hline 17 & 1202150096 & 1680 & 07-JUL-10 & 0.735 & 0 & 0.00595 & 255420001 & -0.000973 and -0.000973 & 0.00595 and 0.00542 \\
\hline 18 & 1202151902 & 1726 & 07-JUL-10 & 0.884 & 0.00719 & 0.0049 & 255478001 & -0.00441 and -0.00436 & 0.0049 and 0.00494 \\
\hline 19 & 1202155661 & 1638 & 13-JUL-10 & 0.362 & 0.52 & 0.01 & 255826001 & -.000942 and -.00795 & 0.01 and 0.00903 \\
\hline 20 & 1202158203 & 1724 & 16-JUL-10 & 0.95 & 0.613 & 0.00404 & 256048001 & -0.000271 and -0.00417 & 0.00404 and 0.00491 \\
\hline 21 & 1202162248 & 1709 & 22-JUL-10 & 0.793 & 0.661 & 0.00407 & 256414001 & 0 and -0.00364 & 0.00407 and 0.00371 \\
\hline 22 & 1202173026 & 1639 & 05-AUG-10 & 0.832 & 01.46 & 0.00784 & 257280001 & 0.00907 and -0.00322 & 0.00784 and 0.00311 \\
\hline 23 & 1202201077 & 1726 & 01-SEP-10 & 0.965 & 0.733 & 0.00327 & 259686002 & 0 and 0.00451 & 0.00327 and 0.00521 \\
\hline 24 & 1202204065 & 1710 & 08-SEP-10 & 0.683 & 0.513 & 0.0142 & 259834001 & 0.0178 and 0.03 & 0.0142 and 0.0191 \\
\hline 25 & 1202213436 & 1692 & 21-SEP-10 & 0.921 & 0.424 & 0.00608 & 260573001 & 0.00788 and 0.0126 & 0.00608 and 0.00932 \\
\hline 26 & 1202215033 & 1694 & 21-SEP-10 & 0.682 & 0.702 & 0.00473 & 260690001 & -0.00452 and 0 & 0.00473 and 0.00437 \\
\hline 27 & 1202218900 & 1695 & 27-SEP-10 & 689 & .563 & .0084 & 261055001 & 0.0108 and 0.019 & 0.0084 and 0.0119 \\
\hline 28 & 1202247815 & 1654 & 04-NOV-10 & .502 & 0 & .00592 & 265418001 & 0 and 0 & 0.00592 and 0.00784 \\
\hline 29 & 1202250869 & 1679 & 05-NOV-10 & .464 & 1.35 & .00693 & 265727001 & -0.0124 and 0 & 0.00693 and 0.00603 \\
\hline
\end{tabular}




\begin{tabular}{|c|c|c|c|c|c|c|c|c|c|}
\hline \multicolumn{10}{|c|}{ Plutonium-239/240 } \\
\hline$\#$ & Sample ID & Inst & Run Date & \begin{tabular}{|c|} 
Tracer \\
Yield \\
\end{tabular} & RER & TPU & $\begin{array}{l}\text { Parent } \\
\text { Sample } \\
\end{array}$ & Result & TPU \\
\hline 1 & 1202251491 & 1713 & 09-NOV-10 & 0.819 & 0.703 & 0.014 & 265781001 & -0.0176 and -0.000426 & 0.014 and 0.02 \\
\hline 2 & 1202257355 & 1726 & $15-\mathrm{NOV}-10$ & 0.756 & 0.701 & 0.0139 & 266510001 & 0.0155 and 0.000704 & 0.0139 and 0.0159 \\
\hline 3 & 1202292563 & 1692 & $31-\mathrm{DEC}-10$ & 0.91 & 0.582 & 0.0125 & 269159001 & 0.0083 and -0.00393 & 0.0125 and 0.0169 \\
\hline 4 & 1202295774 & 1623 & 08-JAN-11 & 0.959 & 1.23 & 0.0149 & 269414001 & 0.0137 and -0.00879 & 0.0149 and 0.0107 \\
\hline 5 & 1202301861 & 1655 & 31-JAN-11 & 0.91 & 0.388 & 0.0333 & 270160001 & 0.00702 and -0.00711 & 0.0333 and 0.0148 \\
\hline 6 & 1202307617 & 1714 & $22-J A N-11$ & 0.851 & 0.25 & 0.00965 & 270577001 & -0.00419 and -0.0075 & 0.00965 and 0.00904 \\
\hline 7 & 1202314740 & 1652 & $05-$ FEB-11 & 0.906 & 0.246 & 0.0179 & 271226001 & 0.0312 and 0.0379 & 0.0179 and 0.0206 \\
\hline 8 & 1202319482 & 1664 & $10-F E B-11$ & 0.976 & 0.0698 & 0.0404 & 271557001 & 0.00524 and 0.00161 & 0.0404 and 0.0327 \\
\hline 9 & 1202321671 & 1676 & 14-FEB-11 & 0.899 & 0.765 & 0.0167 & 271775001 & 0.016 and -0.00611 & 0.0167 and 0.0236 \\
\hline 10 & 1202324649 & 1685 & 18-FEB-11 & 0.861 & 1.47 & 0.105 & 272003001 & 0.826 and 1.06 & 0.105 and 0.122 \\
\hline 11 & 1202329009 & 1629 & $25-\mathrm{FEB}-11$ & 1.05 & 0.6 & 0.794 & 272391001 & 11.5 and 12.2 & 0.794 and 0.855 \\
\hline 12 & 1202333387 & 1675 & 02-MAR-11 & 0.878 & 1.22 & 0.0254 & 272666001 & 0.0537 and 0.0166 & 0.0254 and 0.0165 \\
\hline 13 & 1202336464 & 1713 & 08-MAR-11 & 0.763 & 0.421 & 0.0173 & 272893001 & .0198 and .0105 & 0.0173 and 0.0137 \\
\hline 14 & 1202345368 & 1629 & 19-MAR-11 & 0.597 & 0.247 & 0.0163 & 273714001 & -0.00545 and -0.000173 & 0.0163 and 0.0138 \\
\hline 15 & 1202353306 & 1646 & 29-MAR-11 & 0.81 & 0.163 & 0.0171 & 274310001 & 0.0181 and 0.00689 & 0.0171 and 0.0664 \\
\hline 16 & 1202119815 & 1641 & 26-MAY-10 & 0.475 & 0.623 & 0.0263 & 253072001 & -0.00849 and 0.00959 & 0.0263 and 0.0123 \\
\hline 17 & 1202150096 & 1680 & 07-JUL-10 & 0.735 & 0.232 & 0.0212 & 255420001 & 0.0332 and 0.027 & 0.0212 and 0.0163 \\
\hline 18 & 1202151902 & 1726 & 07-JUL-10 & 0.884 & 0.85 & 0.0179 & 255478001 & 0.0239 and 0.00704 & 0.0179 and 0.00856 \\
\hline 19 & 1202155661 & 1638 & 13-JUL-10 & 0.362 & 0.0902 & .0191 & 255826001 & 0.018 and 0.0157 & 0.0191 and 0.0169 \\
\hline 20 & 1202158203 & 1724 & 16-JUL-10 & 0.95 & 0.332 & 0.0119 & 256048001 & 0.00192 and -0.00303 & 0.0119 and 0.00896 \\
\hline 21 & 1202162248 & 1709 & 22-JUL-10 & 0.793 & 1.63 & 0.0134 & 256414001 & 0.012 and 0.0591 & 0.0134 and 0.0256 \\
\hline 22 & 1202173026 & 1639 & 05-AUG-10 & 0.832 & 0.135 & 0.0214 & 257280001 & 0.00253 and -0.00132 & 0.0214 and 0.0189 \\
\hline 23 & 1202201077 & 1726 & 01 -SEP-10 & 0.965 & 0.0722 & 0.0324 & 259686002 & -0.0042 and -0.00733 & 0.0324 and 0.0288 \\
\hline 24 & 1202204065 & 1710 & 08-SEP-10 & 0.683 & 0.627 & 0.14 & 259834001 & 1.14 and 1.27 & 0.14 and 0.153 \\
\hline 25 & 1202213436 & 1692 & 21-SEP-10 & 0.921 & 0.51 & 0.0673 & 260573001 & 0.443 and 0.493 & 0.0673 and 0.0714 \\
\hline 26 & 1202215033 & 1694 & 21-SEP-10 & 0.682 & 0.255 & 0.0355 & 260690001 & -0.000191 and 0.00981 & 0.0355 and 0.0168 \\
\hline 27 & 1202218900 & 1695 & 27-SEP-10 & 0.689 & 0.353 & 0.0216 & 261055001 & -0.0217 and -0.00763 & 0.0216 and 0.0335 \\
\hline 28 & 1202247815 & 1654 & 04-NOV-10 & 0.502 & 0.298 & 0.0444 & 265418001 & 0.000724 and -0.0148 & 0.0444 and 0.0274 \\
\hline 29 & 1202250869 & 1679 & 05-NOV-10 & 0.464 & 1.55 & 0.0282 & 265727001 & 0.0362 and -0.0182 & 0.0282 and 0.021 \\
\hline
\end{tabular}




\section{Sample Summary}

Overall, the chemical yields for the analytical processes were greater than the minimum yields required in the SOW. Those not meeting the yield requirements are further discussed in the Observation section of this report.

\section{OBSERVATIONS}

\section{Urine}

\section{Americium}

Three Americium blanks are denoted as outliers; however, the results are less than the RDL of $0.02 \mathrm{dpm} / \mathrm{sample}$.

Out of two thousand eight hundred and fourteen yields, thirty-eight are denoted as outliers. Ten $(0.36 \%)$ are less than the low of $40 \%$. Fourteen $(0.46 \%)$ are less than the minimum of $20 \%$.

Out of two hundred and eighty-one Am-241 high LCS's, two (0.71\%) are less than $75 \%$, and one is denoted as an outlier. One $(0.36 \%)$ is greater than $125 \%$ and is denoted as an outlier. There is one more high LCS than low LCS due to the sample 1202073259 not having any recovery or yield (in DUSE).

Out of two-hundred and eighty Am-241 Low LCS's, forty-nine (17.50\%) are less than 75\%. Fifty-one (18.21\%) are greater than $125 \%$. One is denoted as an outlier.

Out of fourteen Am-243 Low LCS's, six (42.86\%) are less than $75 \%$. Four $(28.57 \%)$ are greater than $125 \%$.

One Curium-242 blank is denoted as an outlier; however, the result is less than the RDL of $0.02 \mathrm{dpm} / \mathrm{sample}$.

Out of seven hundred and eighteen Curium yields, five are denoted as outliers. Two $(0.28 \%)$ are less than $40 \%$, and three $(0.42 \%)$ are less than the minimum of $20 \%$.

Out of sixty-nine low Curium LCS's, four (5.80\%) are less than 75\%. Twenty-four (34.8\%) are greater than 125\%.

There is one less high Curium LCS than low LCS due to the LCS 1202073259 not having any recovery or yield (in DUSE).

There are two more Curium blanks than LCS's due to the Curium LCS's (1202141328, 1202141329, 1202197792, and 1202197793) were not spiked for the Curium portion of the Americium/Curium batch. The Americium portion was spiked.

For the QC Summary Table, the Urine Americium-Curium numbers are derived from Americium/Curium section of the database results from the combined Americium/Curium batches plus the single batch of Curium only analysis. From the Americium/Curium combined batches: $281 \mathrm{MB}+281$ High LCS +280 Low LCS $=842 \mathrm{QC}$ samples. There are $2802 \mathrm{Am} / \mathrm{Cm}$ yields so $2802-842=1960$ Reported samples. The Curium only batch has $1 \mathrm{MB}+1$ High $\mathrm{LCS}+1 \mathrm{Low}$ LCS $=3 \mathrm{QC}$ samples. There are $12 \mathrm{Cm}$ only yields total. 12 total samples $-3 \mathrm{QC}$ samples $=9 \mathrm{Cm}$ only Reported Samples. Finally, the two sets of numbers ( $1 \mathrm{from} \mathrm{Am/Cm} \mathrm{combined} \mathrm{batches} \mathrm{and} 1$ from the $\mathrm{Cm}$ only batch) were added together to get the final numbers.

Reported Samples $=9 \mathrm{Cm}$ only $+1960 \mathrm{Am} / \mathrm{Cm}$ combined batch $=1969$

$\mathrm{QC}$ Samples $=3 \mathrm{Cm}$ only $+842 \mathrm{Am} / \mathrm{Cm}$ combined batch $=845$ 
Total Samples $=12 \mathrm{Cm}$ only $+2802 \mathrm{Am} / \mathrm{Cm}$ combined batch $=2814$

\section{Neptunium}

The MDA for Neptunium-237 is greater than the RDL of $0.02 \mathrm{dpm} / \mathrm{sample}$; however, the Contract Limit is satisfied per the SOW because $100 \%$ of the results spiked at contractual decision limit were greater than the decision level.

Out of twenty-two Neptunium yields, one (4.55\%) is less than the low of $50 \%$.

Out of five Neptunium Low LCS's, three (60.00\%) are greater than $125 \%$.

\section{Plutonium}

Eight Plutonium-238 blanks are denoted as outliers; however, the results are less than the RDL

Six Plutonium-239/240 blanks are denoted as outliers; however, the results are less than the RDL.

Out of five thousand nine hundred and eighty-nine Plutonium yields, seventy-five (1.25\%) are less than the minimum of $25 \%$. Three hundred and thirty-nine $(5.66 \%)$ were less than the low of $50 \%$. Sixty-two are denoted as outliers.

Out of five hundred and fifty-eight Plutonium high LCS's, six (1.08\%) are less than $75 \%$. One $(0.18 \%)$ is greater than $125 \%$. Five are denoted as outliers. One Plutonium high LCS is in DUSE.

Out of five hundred and fifty-eight Plutonium Low LCS's, eighty (14.34\%) are less than 75\%. One hundred and twenty-five $(22.40 \%)$ are greater than $125 \%$. Two are denoted as outliers. One Plutonium low LCS is in DUSE.

There are two more high level Plutonium LCS than low level. Sample 1202072720 was lost during the prep phase along with the Strontium portion. Sample 1202218915 had a failing high tracer yield resulting from a low LCS recovery.

\section{Strontium}

Two Strontium blanks are denoted as outliers; however, the results are less than the RDL of $10 \mathrm{dpm} / \mathrm{sample}$.

Out of two thousand one hundred and seventy-two Strontium yields, ten $(0.46 \%)$ are less than the minimum of $25 \%$. One hundred and twenty-two (5.62\%) were less than the low yield of 50\%. Eleven are denoted as outliers.

Out of two hundred and nineteen Strontium high LCS's, one (0.46\%) is less than $75 \%$ and is denoted as an outlier. One $(0.46 \%)$ is greater than $125 \%$. One Strontium high LCS is in DUSE.

Out of two hundred and nineteen Strontium low LCS's, two $(0.91 \%)$ are less than $75 \%$. Forty-three $(19.63 \%)$ are greater than $125 \%$. Two are denoted as outliers. One Strontium low LCS is in DUSE.

There is one less low Strontium LCS than high level due to sample 1202072744 being lost (along with the Plutonium) during the prep phase. 


\section{Thorium}

One Thorium-228, and Th-230 MB is greater than the RDL and is denoted as an outlier; however, this is due to a low tracer yield.

Out of fifty-three thorium yields, four (7.55\%) are denoted as outliers and are less than the minimum of $20 \%$. Two $(3.77 \%)$ are less than the low yield of $50 \%$. One is denoted as an outlier.

One Thorium-229 and one Thorium $232 \mathrm{MB}$ is denoted as an outlier; however, the result is less than the RDL of $0.1 \mathrm{dpm} /$ sample.

Out of twelve Thorium Low LCS's, one (8.33\%) is less than $75 \%$ and is denoted as an outlier. This is due to the low tracer recovery documented by DER 912592 (batch 1057630).

\section{Tritium}

There are no observations for Tritium for this year.

\section{Uranium}

One Uranium-235/236 MB is denoted as an outlier; however, the result is less than the RDL of $0.02 \mathrm{dpm} / \mathrm{sample}$.

Out of seven hundred and seven Uranium yields, five (0.71\%) are less than the low of $40 \%$, and four are denoted as outliers. Twenty $(2.83 \%)$ were less than the minimum of $20 \%$.

Out of ninety-one high LCS's, one (1.10\%) is less than $75 \%$ and is denoted as an outlier. Three $(3.30 \%)$ are greater than $125 \%$. Two Uranium high LCS's are in DUSE.

Out of ninety-one Low LCS's, fifteen (16.48\%) are less than $75 \%$. Twenty-five $(27.47 \%)$ are greater than $125 \%$. One is denoted as an outlier. Two Uranium low LCS's are in DUSE.

The MDA's for Uranium-233/234 and Uranium-238 are greater than the RDL of $0.02 \mathrm{dpm} / \mathrm{sample}$ due to elevated background levels; however, the Urnaium-235 MDA is below the RDL.

\section{Uranium-236 by ICPMS}

Out of thirty-three Uranium-233 yields, one (3.03\%) is less than the minimum of $15 \%$ and is denoted as an outlier. This is due to a prep error that resulted in low tracer yield. 


\section{Uranium-238 by ICPMS and Total Uranium}

Three Uranium-238 by ICPMS MBs are denoted as outliers; however, the results are less than the RDL of 0.06 ug/sample.

Two Uranium-238 by ICPMS matrix spikes are greater than the recovery requirements of $75 \%-125 \%$, one is denoted as an outlier. One of the results was greater than five times the spike, and the spike recovery is not applicable. The other result is outside of GEL's requirement; however, the result was within the relative bias as set by ANSI 13:30 (-0.25 to +0.5).

Three Uranium-238 by ICPMS duplicates are denoted as outliers; however, the results of the parent sample and duplicate are less than 5 times the MDA, and the RPDs are less than the requirement of $100 \%$.

Out of one hundred and fifty (113 U-238 by ICPMS +37 T.U.) Uranium-238 by ICPMS and Total Uranium high LCS's, one $(0.66 \%)$ is greater than $125 \%$, and four are denoted as outliers.

Out of one hundred and fifty (113 U-238 by ICPMS +37 T.U.) Uranium-238 by ICPMS and Total Uranium low LCS's, fifteen ( 3 from U-238 by ICPMS+12 from Total Uranium) $(10.00 \%)$ are less than $75 \%$. Thirteen (8.67\%) are greater than $125 \%$, and one is denoted as an outlier.

Note that the N\# on the MDA study is 150 (113 MB from U-238 by ICPMS + 37 MB from T.U.).

Note that the QC Summary Table's Reported Samples changed. There were 1573 samples reported in the LIMS systems as Uranium-238 (by ICPMS) and 386 samples reported as Total Uranium. The total is 1959. The QC Samples also changed. There were 565 QC Samples reported as Uranium-238 (by ICPMS), and 185 QC samples reported as Total Uranium. The total QC sample is 750 .

Fecal

\section{Americium}

One Americium-241 RER is denoted as an outlier; however, the result is less than 3.

One Am-241 duplicate is denoted as an outlier; however, the results of the parent sample and duplicate are less than 5 times the MDA and are less than the requirement of $100 \%$.

Out of two hundred and sixty Americium yields, three (1.15\%) are less than the low of $40 \%$ and are denoted as outliers. There are 256 yields for Am/Cm batch, 160 QC Samples, and 96 Reported samples (256-160=96). Out of the Am/Cm batch, 4 samples were $\mathrm{Cm}$ only samples. So the Reported Samples will be $96 \mathrm{Am} / \mathrm{Cm}$ combined reported samples $+4 \mathrm{Cm}$ only $=100$. The Total Samples is $256+4=260$. The QC sample numbers do not change because the $\mathrm{Cm}$ only samples were prepped in $\mathrm{Am} / \mathrm{Cm}$ combined batch, and the QC numbers have already been accounted for.

Out of forty-three Am-241 low LCS's, three (6.98\%) are less than $75 \%$. Seven (16.28\%) are greater than $125 \%$.

\section{Curium}

There are no variations for Curium-242 MB or duplicate graphs due to samples having the same results. 


\section{Plutonium}

Two Plutonium-238 blanks are denoted as outliers; however, the results are less than the RDL of $0.2 \mathrm{dpm} / \mathrm{sample}$. One Plutonium-239/240 duplicate is greater than $20 \%$ and is denoted as an outlier; however, the RER is less than 3. Out of two hundred and fifty Plutonium yields, fifteen $(6.00 \%)$ are less than the low of $50 \%$. Five are denoted as outliers.

Out of forty-two Plutonium low LCS's, one (2.38\%) is less than $75 \%$. Five (11.90\%) are greater than $125 \%$.

\section{NRIP/DOELAP}

GEL's results are Lab 2 for DOELAP.

The DOELAP results are sent in a separate package labeled DOELAP. 


\section{Incident Reports}

\section{Incident associated with Work Order 250144, April 19, 2010}

The incident involved a client requested data recheck on the following result: Tagword 10C0877 was reported positive for $\mathrm{Pu}-239$. The sample ID is 250144002.

The data was reviewed by the Group Leader, Bob Timm. Hand calculations of the results confirm. The Pu-239/240 region of interest has 66 net counts over the 42 hour counting period. The background is 1 count. A short 16 hour count was performed to confirm the activity that resulted in 30 net counts in 16 hours so the result confirms with a recount. The sample was in a three sample batch with a blank, high LCS and low LCS. The other two samples in the batch did not have activity present. The matrix blank did not have activity. The high LCS had a recovery of $83.5 \%$ and the low LCS had a recovery of $132 \%$. All recoveries and tracer yields were as expected.

This incident is considered closed.

Incident associated with Work Order 250211, April 21, 2010

The incident involved a client requested data recheck on results for four tagwords (10C0134, 10C0294, 10C0598, $10 \mathrm{C} 0897)$ that were reported positive for $\mathrm{Pu}-239$, and $10 \mathrm{C} 0146$ was positive for $\mathrm{Pu}-238$. They were all routine analyses and received about the same time. The GEL sample IDs are 250211001, 250211003, 250211005, 250542007 , and 250211002 respectively.

GEL Laboratories (GEL) reviewed the radiobioassay sample results for 10C0134 (250211001), $10 \mathrm{C} 0146$ (250211002), 10C0294 (250211003), $10 \mathrm{C} 0598$ (250211005), and 10C0667 (250542007). After review by the Group Leader Bob Timm, the following comments were provided regarding these samples: Sample 10C0134 has nine net counts scattered throughout the $\mathrm{Pu}-239$ region of interest (ROI) and has a background of zero counts. Sample 10C0294 has ten net counts scattered throughout the Pu-239 ROI and has a background of zero counts. Sample $10 \mathrm{C} 0598$ has seven net counts scattered throughout the Pu-239 ROI and has a background of one count. Sample $10 \mathrm{C} 0146$ has six net counts scattered throughout the Pu-238 ROI and has a background of zero counts. Samples 10C0134, 10C0294, 10C0598 and 10C0146 were prepared and analyzed within the same batches. If the samples required fewer counts, this would have made these results below the action level. The Method Blank and five other samples in the batch do not show positive detects. The LCS recovery is $97 \%$ and all other quality control criteria are acceptable. Compared to the other samples in the batch, the spectra for the above samples look a little noisier. There appears to be more erroneous counts outside the plutonium ROI than in the other spectra. This may be due to detector noise or something associated with the chemistry utilized with the procedure. Sample $10 \mathrm{C} 0897$ was in a batch containing eight samples. The Method Blank and eight other samples in the batch do not show positive detects. The LCS recovery is $89.7 \%$ and all other quality control criteria are acceptable. For this sample, there are 17 net counts with a zero background. A peak begins to form in the ROI where you would expect for Pu-239. This sample appears to contain Pu-239 activity based on the spectral data.

This incident is considered closed.

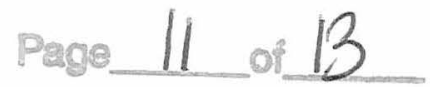




\section{Incident associated with Work Order 254190, June 29, 2010}

The incident involved tagword 10F0447 requested for Neptunium-237 analysis. The analyst Kristi Williams analyzed the batch and has been qualified since May 2010. To investigate if the tracer failure was due to the procedure or reagents, she analyzed synthetic urine samples to verify whether either of these were the source of the error. Ms. Williams prepared and analyzed four LCS to verify the method and per performance. She achieved an average $100 \%$ tracer recovery and a $92 \%$ LCS recovery. This leads GEL to the conclusion that there was an analyst error in performing the original analysis. It was also noted by the Group Leader Bob Timm that a checklist was not available to help assist the analyst with the steps through the process. In resolution, a checklist was created and validated for The Determination of Neptunium in Urine (GL-RAD-B-017).

This corrective action is considered closed.

\section{Incident associated with Work Order 245645, August 04, 2010}

The incident involved a discussion of the possible causes for failing the carbon-14 DOELAP performance test. Because DOELAP accreditation is a condition in the contract SOW, an incident report was requested. No issue was taken with the facts that were provided previously, but a formal report was requested.

Group Leader Robert Timm reviewed the data associated with samples DL1SU0110LB-1 through DL1SU0110LB-6 (Work Order 245945, SDG DLAP0110SUH3C14). No plausible errors could be determined from the data. A description of the samples included that an insoluble material is in the sample provided by DOELAP. GEL suspected that the material may have contained some of the carbon-14 spike. Due to the limited aliquot taken for analysis, with the unknown material the sample, a homogeneous sample was difficult to obtain and this may be the reason for the erroneous results and failures. Laboratory staff attempted to dissolve the material by preserving the samples to a $\mathrm{pH}>2$ with both Nitric Acid and Hydrochloric Acid. Neither acid aided in dissolving the material.

Upon investigation, an additional test on the original DOELAP samples was performed. Three samples were analyzed. One was preserved with Nitric Acid, one with Hydrochloric Acid, and one as received. Each sample was analyzed along with a Matrix Spike performed on the sample. The samples preserved with hydrochloric acid did not analyze well, and results were not obtained. The other samples were consistent with the originally reported results; however, the Matrix Spike showed excellent recovery. This recovery rules out overloading of the carbon-14 trap. The Nitric Acid was also tested for the conversion of Carbon to Carbon dioxide. This follow-up test produced the same results as originally reported. The samples were also analyzed via an oil analysis method utilizing Sulfuric Acid in the beginning, then proceeding as normal. The results were consistent with the originally reported results.

GEL requested a second set of samples from DOELAP. However, the samples were never received. GEL participates in a secondary PE study via the PROCORAD organization. GEL has not had any failures under this PE study. PROCORAD utilizes real urine, while DOELAP prepares their PE samples with synthetic urine. GEL has successfully passed the PROCORAD's PE study.

Upon further investigation, it was determined the problem is not refrigerating the sample upon receipt.

This corrective action is not closed. GEL is awaiting DOELAP sample results for 2011. 


\section{Incident associated with Work Order 256295, August 11, 2010}

The incident involved a lab error made by an analyst that resulted in 8 samples being reported as Failed Analysis for Strontium. Tagwords 10G0777, 10G0796, 10G0003, 10G0084, 10G0120, 10G0780, 10G0797 and 10G0800 were the affected work orders. The error occurred when running Isotopic Plutonium and Strontium sequentially on a single batch of samples. The analyst, Christina Kimball, inadvertently used centrifuge tubes labeled as Strontium to catch her Plutonium elution and vice versa. On the day of the error and before the error was noticed, she took the samples labeled Plutonium and precipitated them as $\mathrm{Pu}$ and then filtered. These were turned into the count room for analysis. In hindsight, these were the Strontium elutions. On the day following the error, she noticed that her samples labeled Strontium had $25 \mathrm{~mL}$ of liquid when they should only have $15 \mathrm{~mL}$. The Group Leader was consulted. The incident was investigated. The Plutonium results were checked, as the samples had already started counting. There was no tracer yield on the samples, so, at that time, it was suspected that the $\mathrm{Pu} \& \mathrm{Sr}$ samples were switched. The samples labeled Strontium were precipitated as Plutonium, filtered saving the liquid residue, counted and verified Plutonium tracer peaks were present. Thus, we were able to recover and report the Plutonium fraction, but the Strontium fraction was lost in analysis due to precipitating and filtering the samples as Plutonium. In resolution, the analyst was reminded to stay focused.

This corrective action is considered closed.

Incident associated with Work Order 257200, August 17, 2010

The incident involved a batch of routine isotopic uranium samples containing work orders 257200 and 257698 , which were reported as failed analysis. The affected tagwords are 10G0190, 10G0285, 10G0310, 10G0406, 10G1033, 10G1034, 10G1036, 10G1037 and 10G1038. The analyst, Christina Kimball, apparently made an error either omitting a chemical, using the wrong chemical, failing to trace \& spike, failure to add Neodymium or reduce Uranium with Titanium Chloride during the final precipitation step, and etc. results in the entire batch having no tracer yields. The reason for the error is the same in all cases- due to the lack of attention to detail. In resolution, a checklist was implemented for the analysts to follow while proceeding through the complex preparation and separation procedures. The checklists are an aid to perform the steps as outlined in the Standard Operating Procedure to ensure all steps are followed as written. The analyst was re-trained and reminded to stay focused.

This corrective action is considered close.

Incident associated with Work Order 261194, October 19, 2010

The incident involved Tagwords 10I0144, 10I0145, 10I0156, 10I0196, 10I0269, 10I0274, 10I0332, 10I0409, and $10 \mathrm{I0641}$ for Plutonium analysis all have failing tracer yields. The highest is $17.656 \%$ for sample $10 \mathrm{I0196}$. However, overall the average is about $5 \%$. No LCS recovery was calculated either due to the failing tracer yields. The prep analyst was consulted and did not notate any errors/issues with the batch. The entire sample was consumed for analysis, and no samples remain for re-preps. The results are reported as Failed Analysis. The strontium portion has already been completed, and all those results are within requirements. Upon further investigation and review, it was discovered through the batch checklist that we have a step that can be omitted when $\mathrm{Am} \& \mathrm{Pu}$ are not required e.g. uranium only analysis. This specific set of samples had only Pu \& Sr. The analyst (our newest one) omitted the Americium rinse step. This results in the $\mathrm{TiCl} 3$ rinse which reduces the $\mathrm{Pu}$ and allows it to elute from the cartridge being added to a HNO3 environment vs. a HCL environment on the cartridge, which may have been responsible for the low yields. In resolution, the group leader discussed this with the analyst. This analyst had performed several $\mathrm{Am}, \mathrm{Pu} \& \mathrm{Sr}$ batches over the past couple of months but had not performed $\mathrm{Pu}$ without Am. A training issue was discovered and was corrected.

This corrective action is considered closed.

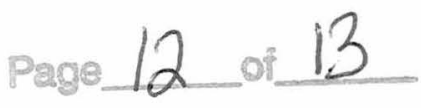




\section{Incident associated with Work Order 268491, January 12, 2011}

This incident involved sample with tagword 10L0551 which was received and logged via normal protocol. The single sample contained 4 tagwords each getting a different in house sample ID. Sr-90 should have been analyzed sequentially with $\mathrm{Am}, \mathrm{Pu}, \mathrm{Cm}$ and $\mathrm{U}$. Analyst I Chrissi Kimball has the duties of batching samples. When batching sample 10L0551, the paperwork was inadvertently not included with the paperwork for $\mathrm{Am}, \mathrm{Pu}, \mathrm{Cm}$ and $\mathrm{U}$ analysis. When preparing the samples, the prep analyst, Julie Williams, did not notice the sample required $\mathrm{Sr}-90$ and proceeded with analysis and did not perform Sr-90 analysis on the sample. The Sr-90 fraction was lost during analysis. In resolution, the Group Leader, Bob Timm, gathered Julie, Chrissi and other analysts who analyze similar type samples and performed on the spot training discussing the error.

This corrective action is considered closed.

\section{Incident associated with Work Order 270079, January 19, 2011}

The incident involved samples with tagwords 11A0700, 10L0475, 11A0222, 11A0341, 11A0484, 11A0500, 11A0501, 11A0539 and 11A0707. The samples are in work order's 270079, 270081 and 270183. An analyst error resulted in 9 isotopic uranium samples, from a single batch, to be reported as Failed Analysis. The analyst failed to catch the Uranium fraction as they confused this analysis which was $\mathrm{Pu} / \mathrm{U}$ with $\mathrm{Am} / \mathrm{Pu}$.

Upon investigation by the Group Leader Bob Timm, it was discovered that the error occurred while performing the column separations for batches 1063614 and 1063616, which were being analyzed sequentially. While preparing the chemical separations, the analyst set up the batches for Americium and Plutonium cartridges instead of the required Plutonium and Uranium cartridges. The error was not identified until the day after the separations took place and all of the waste fractions and the cartridges containing the Uranium fraction had been discarded.

In resolution, Mr. Timm reviewed this occurrence with the preparation analysts of the laboratory. He discussed the importance of a new procedural change for chemical separations. The lab analysts have been instructed to perform and document a witness evaluation just prior to chemical separations and immediately after chemical separations. Prior to the separation, a second analyst will examine the setup for separations and verify on the paperwork that all required analytes are being separated properly. This will be documented on the upper left hand corner of the laboratory batch sheet. At the end of the chemical separations and before discarding any wastes or resin cartridges, a second analyst will examine the retained fractions and verify all required analytes have been prepared. This will be documented by an additional set of initials and date on the batch checklist. Documentation of this training session is on file for each analyst in attendance.

This corrective action is considered closed.

\section{Incident associated with Work Order 272967, March 09, 2011}

The incident involved Tagword 11B0961. There was an issue with an incorrect status assignment of a sample within SDG 272967. Upon investigation, GEL's CST department audited the table that contained the data and was able to determine the sequence of events of the sample status change; however, they did not have a program in place to alert someone when a status change occurs that should not. In resolution, CST has programmed an email notification that will be sent to the Project Manager whenever a sample is status to IS (insufficient sample).

This corrective action is considered closed. 
Incident associated with Work Order 273390, March 31, 2011

The incident involved samples with tagwords 11B0724, 11C0330, 11C0536, and 11C0396. A prep error occurred which resulted in four samples reported as a failed analysis for Plutonium due to low tracer yields. Analyst Dave Johnston prepared the samples. Group leader Bob Timm reviewed the data for any potential error. Mr. Johnston prepared a batch for another client before this batch, and it had a lower average tracer yield. Two other prep analysts are performing well so this does not appear to be a method problem, only the execution of the method by the analyst.

In resolution, Mr. Johnston has been removed from Plutonium in urine analysis until a remedial qualification can be performed.

This corrective action is considered closed.

\section{Corrective Actions}

There is one corrective action at this time pertaining to work order 245645. 



\section{APPENDIX C}

QUALITY CONTROL INTERCOMPARISON PARTICIPATION

$\underline{\text { RESULTS }}$

(Historical File Only) 



\section{SECTION 3 \\ DOELAP/NRIP RESULTS}




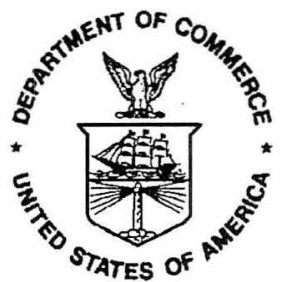

Test Identification:

Test Radionuclides:

Matrix Description:

Test Activity Range:

Reference Time:
U.S. DEPARTMENT OF COMMERCE

National Institute of Standards and Technology

Gaithersburg, MD

REPORT OF TRACEABILITY

General Engineering Laboratories, LLC Charleston, South Caroline

\begin{tabular}{|c|c|c|c|c|c|}
\hline \multirow[t]{2}{*}{ Nuclide } & \multicolumn{2}{|c|}{ NIST Value ${ }^{2,3}$} & \multicolumn{2}{|c|}{ Reported Value $^{4}$} & \multirow{2}{*}{$\begin{array}{l}\text { Difference }^{5} \\
( \pm \% \text { Bias })\end{array}$} \\
\hline & $\begin{array}{c}\text { Massic Activity } \\
\mathrm{Bq} \cdot \mathrm{g}^{-1}\end{array}$ & $\begin{array}{r}\text { Relative Expanded } \\
\text { Uncertainty }(\%, \mathrm{k}=2) \\
\end{array}$ & $\begin{array}{c}\text { Massic Activity } \\
\mathrm{Bq} \cdot \mathrm{g}^{-1}\end{array}$ & $\begin{array}{r}\text { Relative Expanded } \\
\text { Uncertainty }(\%, \mathrm{k}=2)\end{array}$ & \\
\hline${ }^{241} \mathrm{Am}$ & 0.763 & 0.82 & 0.650 & 11.8 & -14.8 \\
\hline${ }^{238} \mathrm{Pu}$ & 0.511 & 0.71 & 0.449 & 19.6 & -12.2 \\
\hline${ }^{240} \mathrm{Pu}$ & 0.785 & 0.79 & 0.722 & 12.5 & -8.11 \\
\hline${ }^{230} \mathrm{Th}$ & 1.036 & 0.61 & 0.924 & 19.7 & -10.8 \\
\hline${ }^{238} \mathrm{U}$ & 0.912 & 0.63 & 0.888 & 12.1 & -2.7 \\
\hline${ }^{234} \mathbf{U}$ & 0.879 & 0.98 & 0.912 & 12.0 & 3.8 \\
\hline${ }^{235} \mathrm{U}$ & 0.042 & 0.80 & 0.041 & 51.8 & -1.9 \\
\hline${ }^{90} \mathrm{Sr}$ & 71.5 & 0.77 & 68.0 & 10.3 & -4.9 \\
\hline${ }^{137} \mathrm{Cs}$ & 73.6 & 0.72 & 69.7 & 16.0 & -5.2 \\
\hline${ }^{60} \mathrm{Co}$ & 37.3 & 0.54 & 35.8 & 22.4 & -3.9 \\
\hline \multicolumn{3}{|c|}{ NR $=$ Not Reported } & & \multicolumn{2}{|c|}{ NA $=$ Not Applicable } \\
\hline \multicolumn{6}{|c|}{ Methods } \\
\hline \multirow{2}{*}{\multicolumn{2}{|c|}{ Activity Measurements }} & \multicolumn{2}{|c|}{ NIST $^{6}$} & \multicolumn{2}{|c|}{ Reporting Laboratory $^{7}$} \\
\hline & & \multicolumn{2}{|c|}{$\begin{array}{c}\text { Alpha- and Beta-Spectrometry } \\
\text { Mass Spectrometry }\end{array}$} & \multicolumn{2}{|c|}{ Alpha, Beta, and Gamma Spectrometry } \\
\hline
\end{tabular}

NRIP-10-SF

${ }^{241} \mathrm{Am},{ }^{238} \mathrm{Pu},{ }^{240} \mathrm{Pu},{ }^{230} \mathrm{Th},{ }^{238} \mathrm{U},{ }^{235} \mathrm{U},{ }^{234} \mathrm{U},{ }^{90} \mathrm{Sr},{ }^{237} \mathrm{~Np},{ }^{60} \mathrm{Co},{ }^{137} \mathrm{Cs}$

Synthetic Feces ${ }^{1}$

$30 \mathrm{mBq} \bullet$ sample $^{-1}$ to $300 \mathrm{mBq} \bullet \mathrm{sample}^{-1}$

12:00 EST, April 1, 2010

Measurement Results

on (per ANSI N42.22 and N13.30)

\begin{tabular}{|c|c|c|c|c|}
\hline \multirow[t]{3}{*}{ Nuclide } & \multicolumn{2}{|c|}{$\mathrm{N} 42.22^{8}$} & \multirow{2}{*}{\multicolumn{2}{|c|}{$\begin{array}{c}\text { N13.30 } \\
\text { Results Acceptable per N13.30 Criteria } \\
\text { (Pass/Fail) }\end{array}$}} \\
\hline & \multirow[t]{2}{*}{$\begin{array}{c}\text { ANSI N42.22 } \\
\text { Traceable }\end{array}$} & \multirow{2}{*}{$\begin{array}{l}\text { Traceability } \\
\text { Limit } \\
\text { (土Percent) }\end{array}$} & & \\
\hline & & & Bias & Precision \\
\hline${ }^{241} \mathrm{Am}$ & Yes & 15 & Pass & Pass \\
\hline${ }^{238} \mathrm{Pu}$ & Yes & 26 & Pass & Pass \\
\hline${ }^{240} \mathrm{Pu}$ & Yes & 17 & Pass & Pass \\
\hline${ }^{230} \mathrm{Th}$ & Yes & 26 & Pass & Pass \\
\hline${ }^{238} \mathrm{U}$ & Yes & 18 & Pass & Pass \\
\hline${ }^{234} U$ & Yes & 19 & Pass & Pass \\
\hline${ }^{235} \mathrm{U}$ & Yes & 76 & Pass & Pass \\
\hline${ }^{90} \mathrm{Sr}$ & Yes & 15 & Pass & Pass \\
\hline${ }^{137} \mathrm{Cs}$ & Yes & 23 & Pass & Pass \\
\hline${ }^{60} \mathrm{Co}$ & Yes & 32 & Pass & Pass \\
\hline
\end{tabular}

Samples Distributed

August 12, 2010

Reporting Data Received

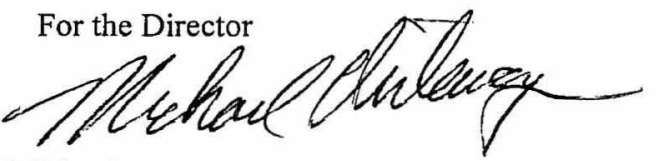

Michael Unterweger,

Group Leader

Radioactivity Group

Physics Laboratory

(Continued) 


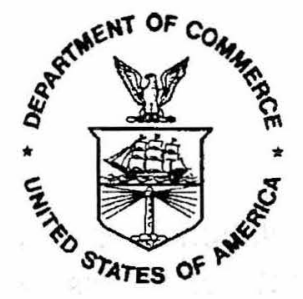

U.S. DEPARTMENT OF COMMERCE

National Institute of Standards and Technology

Gaithersburg, MD

\section{REPORT OF TRACEABILITY}

\section{General Engineering Laboratories, LLC Charleston, South Caroline}

Test Identification:

Test Radionuclides:

Matrix Description:

Test Activity Range:

Reference Time:
NRIP-10-SF

${ }^{241} \mathrm{Am},{ }^{238} \mathrm{Pu},{ }^{240} \mathrm{Pu},{ }^{230} \mathrm{Th},{ }^{238} \mathrm{U},{ }^{235} \mathrm{U},{ }^{234} \mathrm{U},{ }^{90} \mathrm{Sr},{ }^{237} \mathrm{~Np},{ }^{60} \mathrm{Co},{ }^{137} \mathrm{Cs}$

Synthetic Feces ${ }^{l}$

$30 \mathrm{mBq} \cdot$ sample $^{-1}$ to $300 \mathrm{mBq} \cdot \mathrm{sample}^{-1}$

12:00 EST, April 1, 2010

Measurement Results

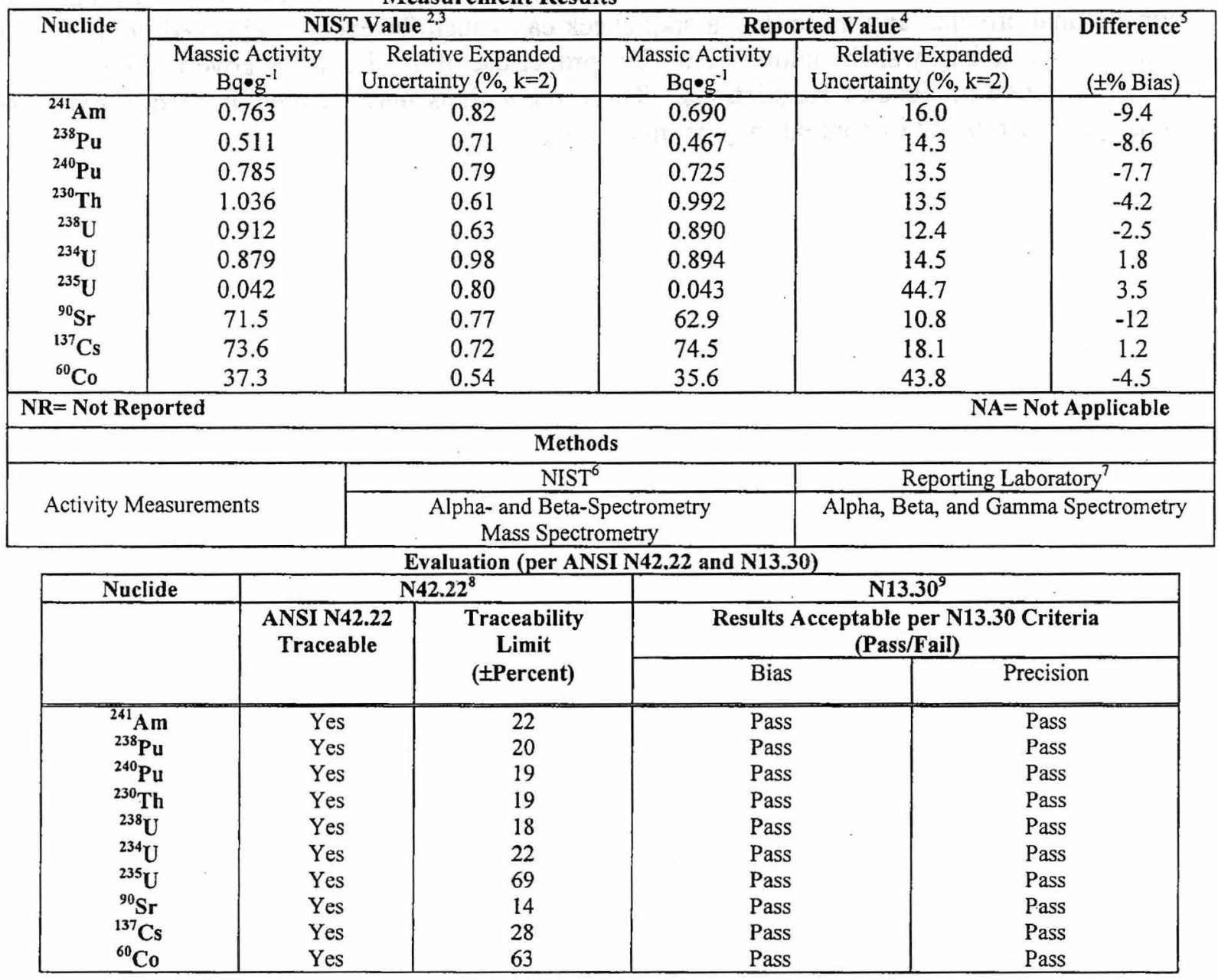

Samples Distributed

Reporting Data Received
August 12, 2010

October 15,2010

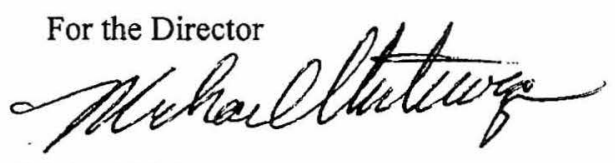

Michael Unterweger,

Group Leader

Radioactivity Group

Physics Laboratory

(Continued) 
As guidance for the proper use of this Report, it should be emphasized that the National Institute of Standards and Technology is concerned only with fostering good measurement capability and consistency with the national measurements system. The assurance of the proper application of that capability to the ultimate consumer products is the responsibility of each manufacturer and of the Federal regulatory agencies.

A continuing traceability program in radioactivity demonstrates, to the degree established by the periodic assays of calibrated radioactivity samples, a continuing competence to maintain the instrument systems and standards necessary for accurate measurement. Such a program cannot, however, endorse each and every measurement nor the final product, any more than a spot check can vouch for every unchecked item. Care should be taken, therefore, not to imply such endorsement. The proper use of this Report is governed by section 200.114 of Title 15 of the Code of Federal Regulations. These regulations may be met if Reports are quoted only in their entirety. Excerpts out of context may be misleading. 


\section{Notes}

(1a) Five test-samples and three (identical matrix) blanks were provided for this test. Each sample consisted of approximately 100 grams of synthetic fecal material contained in a plastic zip-lock bag that was packed in a plastic container.

\section{Composition of the Synthetic Feces}

\begin{tabular}{|c|c|}
\hline Reagent & g/sample \\
\hline Calcium Nitrate & 0.97 \\
\hline Ferric Ammonium Sulfate & 0.04 \\
\hline Magnesium Carbonate & 0.61 \\
\hline Potassium Carbonate & 0.83 \\
\hline Ammonium Dihydrogen Phosphate & 2.1 \\
\hline Sodium Sulfate & 0.37 \\
\hline Ammonium Chloride & 0.04 \\
\hline Zinc Sulfide & 0.01 \\
\hline Stannous Chloride & 0.03 \\
\hline Leucine & 7.1 \\
\hline Lysine & 5.1 \\
\hline Methionine & 0.8 \\
\hline Threonine & 2 \\
\hline Palmitic Acid & 3 \\
\hline Stearic Acid & 2 \\
\hline Cellulose & 4 \\
\hline Gelatin & 5 \\
\hline Oleic Acid (Liquid) & 1 \\
\hline Peanut Oil & 1.5 \\
\hline Water (distilled) & 65 \\
\hline
\end{tabular}

(1b) The test samples were prepared by depositing a known amount of a NIST calibrated "spike". solution (aqueous solution containing known quantities of ${ }^{241} \mathrm{Am}{ }^{241} \mathrm{Am},{ }^{238} \mathrm{Pu},{ }^{240} \mathrm{Pu},{ }^{230} \mathrm{Th},{ }^{238} \mathrm{U},{ }^{235} \mathrm{U},{ }^{234} \mathrm{U},{ }^{90} \mathrm{Sr},{ }^{60} \mathrm{Co},{ }^{57} \mathrm{Co},{ }^{137} \mathrm{Cs},{ }^{210} \mathrm{~Pb},{ }^{210} \mathrm{Po},{ }^{226} \mathrm{Ra}$, and ${ }^{243} \mathrm{Cm}$ to the center of individual ashless paper filters (37 mm diameter). After deposition of this solution, filters were dried overnight. Once dry, each filter was sandwiched between two unspiked filters. Each sandwich was then slipped into a lowdensity polyethylene sleeve (wall density $\sim 0.1 \mathrm{~mm}$ ) and sealed for counting. After confirmation measurement, each spiked filter pack was placed inside of the matrix contained plastic zip-lock bag (1a) for packaging and shipment.

(2a) Solutions of tracers were prepared by gravimetric dilutions of NIST Standard Reference Material SRM's or NIST calibrated solutions. The dilution factors at each step were confirmed by radioactivity measurements.

(2b) The analysis methodology and nomenclature used for the NIST uncertainties are based on uniform guidelines [cf., B.N. Taylor and C. E. Kuyatt, NIST Technical Note 1297 (1994)] and are compatible with those adopted by the principal international metrology standardization bodies. Individual uncertainties have the significance of one standard deviation of the mean, or an approximation thereof. The relativ698nbined uncertainty is the quadratic combination of the standard 
deviation (or standard deviation of the mean where appropriate), or approximation thereof, for the following component uncertainties:

\section{Nuclide (SRM Identification) $\quad$ Uncertainty $(\%, 1 \mathrm{~s})$}

$\begin{array}{llc}\text { a) } & { }^{57} \mathrm{Co}(\text { NIST calibration }) & 1.77 \\ \text { b) } & { }^{60} \mathrm{Co}(4915 \mathrm{~F}) & 0.25 \\ \text { c) } & { }^{137} \mathrm{Cs}(4233 \mathrm{D}) & 0.34 \\ \text { d) } & { }^{90} \mathrm{Sr}(4919 \mathrm{H}) & 0.37 \\ \mathrm{e}) & { }^{210} \mathrm{Po}(4337) & 2.5 \\ \text { f) } & { }^{210} \mathrm{~Pb}(4337) & 2.5 \\ \text { g) } & { }^{226} \mathrm{Ra}(4966) & 0.44 \\ \text { h) } & { }^{234} \mathrm{U}(4321 \mathrm{C}) & 0.49 \\ \text { i) } & { }^{235} \mathrm{U}(4321 \mathrm{C}) & 0.31 \\ \text { j) } & { }^{238} \mathrm{U}(4321 \mathrm{C}) & 0.30 \\ \mathrm{k}) & { }^{238} \mathrm{Pu}(4323 \mathrm{~B}) & 0.34 \\ \text { l) } & { }^{240} \mathrm{Pu}(4338 \mathrm{~A}) & 0.38 \\ \mathrm{~m}) & { }^{241} \mathrm{Am}(4322 \mathrm{~B}) & 0.48 \\ \text { n) } & { }^{243} \mathrm{Cm}(4329) & 0.47 \\ \text { i) } & \text { Gravimetrics (dilutions) } & 0.05\end{array}$

The individual certified uncertainties of standard reference materials are based on the quadratic combination of all sources of uncertainty manifested in the preparation of the material. These uncertainties may result from uncertainties from any or all of the following: alpha-decay emission rate, background, balance calibration, decay corrections, decay-scheme data, extrapolation of alpha-particle-count-rate-versus-energy to zero energy, live time, alpha-particle detection efficiency, alphaemitting impurities, gamma-emitting impurities.

The Relative Expanded Uncertainty is obtained by multiplying the standard uncertainty by a coverage factor of $\mathbf{k}=\mathbf{2}$ and is assumed to provide an uncertainty interval of approximately 95 percent confidence.

(3) Half-lives used

$\begin{array}{lll} & \text { Nuclide } & \text { Half-life } \\ \text { a) } & { }^{57} \mathrm{Co} & 271.79 \pm 0.09 \mathrm{~d} \\ \text { b) } & { }^{60} \mathrm{Co} & 5.2714 \pm 0.0005 \mathrm{y} \\ \text { c) } & { }^{90} \mathrm{Sr} & 28.78 \pm 0.04 \mathrm{y} \\ \text { d) } & { }^{137} \mathrm{Cs} & 30.07+0.03 \mathrm{y} \\ \text { e) } & { }^{210} \mathrm{Po} & 138.376 \pm 0.002 \mathrm{~d} \\ \text { f) } & { }^{210} \mathrm{~Pb} & 22.20 \pm 0.22 \mathrm{y} \\ \text { g) } & { }^{226} \mathrm{Ra} & 1600 \pm 7 \mathrm{y} \\ \text { h) } & { }^{230} \mathrm{Th} & (7.538 \pm 0.030) \times 10^{4} \mathrm{y} \\ \text { h) } & { }^{234} \mathrm{U} & (2.455 \pm 0.006) \times 10^{5} \mathrm{y} \\ \text { i) } & { }^{235} \mathrm{U} & (7.038+0.005) \times 10^{8} \mathrm{y} \\ \text { j) } & { }^{238} \mathrm{U} & (4.468 \pm 0.003) \times 10^{9} \mathrm{y} \\ \text { k) } & { }^{238} \mathrm{Pu} & 87.74 \pm 0.04 \mathrm{y} \\ \text { l) } & { }^{240} \mathrm{Pu} & 6564 \pm 11 \mathrm{y} \\ \text { m) } & { }^{241} \mathrm{Am} & 432.2 \pm 0.5 \mathrm{y} \\ \text { n) } & { }^{243} \mathrm{Cm} & 28.5 \pm 0.2 \mathrm{y}\end{array}$

Note: Half-life data are based on NIST certificates (Note 2b) or Evaluated Nuclear Structure

Data File (ENSDF 2010). Uncertainties quoted at one sigma level.

(4) The laboratory value represents the mean of five replicate measurements. The reported uncertainty was multiplied by a coverage factor of $\mathbf{k}=\mathbf{2}$.

(5) The Difference quoted is the difference between the NIST Value and Reported Value, expressed as a percent relative to the NIST Value.

(6) Test samples were prepared by gravimetric dilutions of NIST calibrated solutions and SRM's. These solutions and SRM's were calibrated using the following activity measurement methodologies:

\section{Nuclide $\quad$ Methodology 639}


$\begin{array}{ll}\text { a) } & { }^{60} \mathrm{Co} \\ \text { b) } & { }^{57} \mathrm{Co} \\ \text { c) } & { }^{90} \mathrm{Sr} \\ \text { d) } & { }^{137} \mathrm{Cs}\end{array}$

e) ${ }^{210} \mathrm{Po}\left({ }^{210} \mathrm{Po}\right)$

f) ${ }^{210} \mathrm{~Pb}$

g) $\quad{ }^{226} \mathrm{Ra}$

h) $\quad{ }^{230} \mathrm{Th}$

i) ${ }^{234} \mathrm{U},{ }^{235} \mathrm{U},{ }^{238} \mathrm{U}$

j) $\quad{ }^{238} \mathrm{Pu}$

k) $\quad{ }^{240} \mathrm{Pu}$

l) $\quad{ }^{241} \mathrm{Am}$

m) $\quad{ }^{243} \mathrm{Cm}$
Pressurized " $4 \pi$ " $\gamma$ ionization chamber " $A$ " calibrated using a cobalt- 60 solution whose activity was determined by " $4 \pi$ "- $(\beta+\gamma)$-coincidence and anti-coincidence counting

Pressurized " $4 \pi$ " $\gamma$ ionization chamber " $A$ " calibrated using a cobalt- 60 solution whose activity was determined by " $4 \pi$ "- $(\beta+\gamma)$-coincidence and anti-coincidence counting

NIST $4 \pi \beta$ liquid-scintillation counting system

Pressurized " $4 \pi$ "- $\gamma$-ionization chamber " $A$ " calibrated using a cesium-137 solution whose activity was determined by " $4 \pi$ "- $(\mathrm{e}+\mathrm{X})-\gamma$-anti-coincidence counting

Pressurized " $4 \pi$ " gamma ionization chamber " $A$ " calibrated using a barium- 133 solution whose number of cesium-137 atoms was determined by isotope-dilution mass spectrometry $4 \pi \alpha \beta$ liquid-scintillation counting system

$4 \pi \alpha \beta$ liquid-scintillation counting system

Pressurized " $4 \pi$ " $\gamma$ ionization chamber " $A$ "

Two $4 \pi \alpha$ liquid scintillation counting systems

Mass spectrometry, silicon surface barrier alpha-detection, and

$4 \pi(\alpha+\beta)$ liquid-scintillation counting systems

NIST " $0.1 \pi$ " $\alpha$ defined-solid-angle scintillation detector

Two $4 \pi \alpha$ liquid scintillation counting systems

Two $4 \pi \alpha$ liquid scintillation counting systems

$4 \pi \alpha$ liquid-scintillation counting system

NIST " $0.8 \pi$ " alpha and " $0.1 \pi$ " alpha defined-solid-angle

counters with scintillation detectors

(7) Summary of the reporting laboratory methodologies.

(8)

ANSI N42.22 defines the acceptance criteria for verification testing by NIST as:

$$
\left|V_{R}-V_{N}\right|<3 * \sqrt{u_{c}^{2}(N)+u_{c}^{2}(R)}
$$

Where: $\quad V_{N}=$ NIST Value;

$\mathrm{V}_{\mathrm{R}}=$ Reported Value;

$\mathrm{u}_{\mathrm{c}}(\mathrm{N})=$ standard combine uncertainty of the NIST value, $\mathrm{V}_{\mathrm{N}}$;

$\mathrm{u}_{\mathrm{c}}(\mathrm{R})=$ standard combine uncertainty of the Laboratory value, $\mathrm{V}_{\mathrm{R}}$; and

$3 * \sqrt{u_{c}^{2}(N)+u_{c}^{2}(R)}=$ Traceability Limit (limit to which measurement traceability may be claimed with $99 \%$ confidence)

ANSI N13.30 defines criteria for acceptable bias between -25 and +50 percent, and acceptable precision between -40 and +40 percent, 1 sigma total propagated uncertainty.

Reference:

ANSI National Standards Institute, ANSI N42.22-1995, "Traceability of Radioactive Sources to the National Institute of Standards and Technology (NIST) and Associated Instrument Quality Control."

ANSI National Standards Institute, ANSI N13.30-1996, "Performance Criteria for Radiobioassay."

Information contacts:

Dr. Kenneth G. W. Inn

(301) $975-5541$

kenneth.inn@nist.gov

Ms. Svetlana Nour

(301) 975-4927 Svetlana.nour@nist.gov 


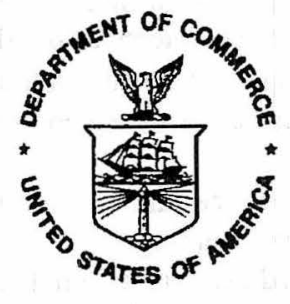

Test Identification:

Test Radionuclides:

Matrix Description:

Test Activity Range:

Reference Time:
U.S. DEPARTMENT OF COMMERCE

National Institute of Standards and Technology

Gaithersburg, MD

\section{REPORT OF TRACEABILITY}

\section{General Engineering Laboratories, LLC Charleston, South Carolina}
NRIP10-SU Set \#
${ }^{57} \mathrm{Co},{ }^{60} \mathrm{Co},{ }^{90} \mathrm{Sr},{ }_{213} \mathrm{Cs},{ }^{210} \mathrm{~Pb},{ }^{210} \mathrm{Po},{ }^{226} \mathrm{Ra},{ }^{230} \mathrm{Th},{ }^{234} \mathrm{U},{ }^{235} \mathrm{U},{ }^{238} \mathrm{U},{ }^{238} \mathrm{Pu}$, Synthetic Urine ${ }^{240} \mathrm{Pu},{ }^{241} \mathrm{Am},{ }^{243} \mathrm{Cm}$, gross alpha, gross beta in acidified water ${ }^{1}$
$30 \mathrm{mBq} \bullet \mathrm{sample}^{-1}$ to $300 \mathrm{mBq} \bullet \mathrm{sample}^{-1}$
12:00 EST, August 1, 2010

Measurement Results

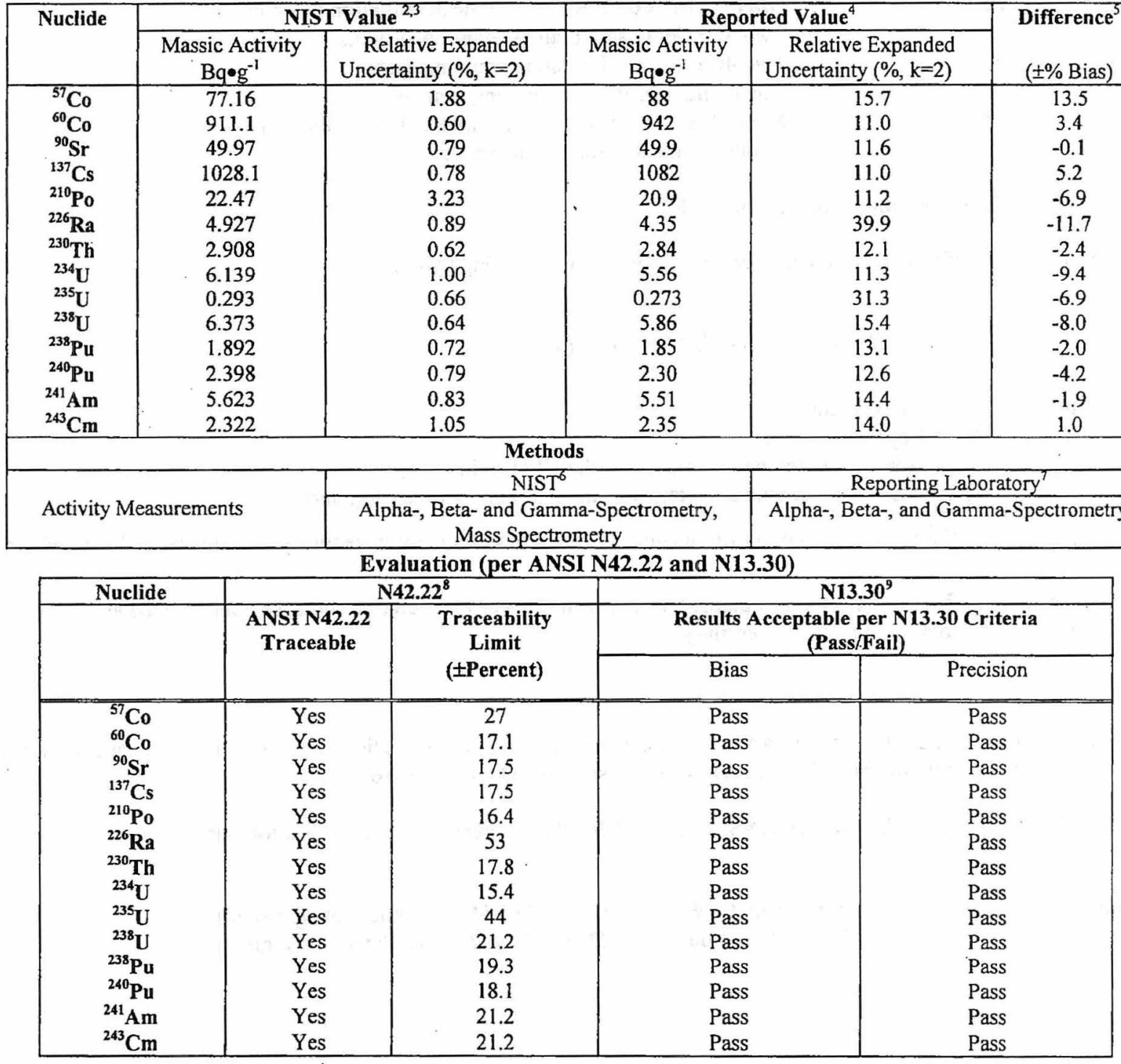

Samples Distributed

Reporting Data Received
July 15,2010

September 14, 2010
For the Director

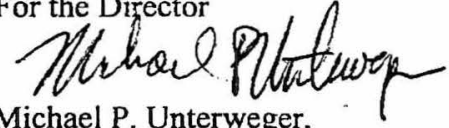

Group Leader

Radioactivity Group

(Continued) 
(1a) Five test-samples and three (identical matrix) blanks were provided for this test. Each sample consisted of approximately 1000 or 100 grams of synthetic urine material contained in a $1-\mathrm{L}$ or $125 \mathrm{~mL}$ size polyethylene bottle.

\section{Composition of the Synthetic Urine}

\begin{tabular}{|l|l|c|}
\hline \multicolumn{2}{|l|}{ Reagent } & $\begin{array}{c}\text { Weight/1L Sample } \\
\text { (g) }\end{array}$ \\
\hline \hline $\mathrm{H}_{2} \mathrm{C}_{2} \mathrm{O}_{4} \cdot 2 \mathrm{H}_{2} \mathrm{O}$ & Oxalic Acid & 0.02 \\
\hline Pepsin & Pepsin & 0.029 \\
\hline $\mathrm{CH}_{3} \mathrm{CHOHCO}_{2} \mathrm{H}$ & Lactic Acid (liquid) & 0.094 \\
\hline $\mathrm{MgSO}_{4} \cdot 7 \mathrm{H}_{2} \mathrm{O}$ & Magnesium Sulfate & 0.46 \\
\hline $\mathrm{C}_{5} \mathrm{H}_{11} \mathrm{O}_{5} \mathrm{CHO}$ & Glucose (dextrose) & 0.48 \\
\hline $\mathrm{Citric}_{\mathrm{Acid}}$ & Citric Acid & 0.54 \\
\hline $\mathrm{CaCl}_{2} \cdot 2 \mathrm{H}_{2} \mathrm{O}$ & Calcium Chloride & 0.63 \\
\hline $\mathrm{C}_{9} \mathrm{H}_{9} \mathrm{NO}_{3}, 98 \%$ & Hippuric Acid & 0.63 \\
\hline $\mathrm{Na}_{2} \mathrm{SiO}_{3} \cdot 9 \mathrm{H}_{2} \mathrm{O}$ & Sodium Silicate & 0.071 \\
\hline $\mathrm{NH}_{4} \mathrm{Cl}_{9}, 99 \%$ & Ammonium Chloride & 1.06 \\
\hline $\mathrm{C}_{4} \mathrm{H}_{9} \mathrm{~N}_{3} \mathrm{O}_{2} \cdot \mathrm{H}_{2} \mathrm{O}$ & Creatine & 1.1 \\
\hline $\mathrm{NaCl}_{9} 99+\%$ & Sodium Chloride & 2.32 \\
\hline $\mathrm{NaH}_{2} \mathrm{PO}_{4} \cdot \mathrm{H}_{2} \mathrm{O}$ & Sodium Dihydrogen Phosphate & 2.73 \\
\hline $\mathrm{KCl}$ & Potassium Chloride & 3.43 \\
\hline $\mathrm{Na}_{2} \mathrm{SO}_{4}$ & Sodium Sulfate & 4.31 \\
\hline $\mathrm{CH}_{4} \mathrm{~N}_{2} \mathrm{O}, 98 \%$ & Urea & 16 \\
\hline $\mathrm{HNO}_{3}$ & Concentrated nitric acid $(50 \mathrm{~mL})$ & 70.7 \\
\hline $\mathrm{H}_{2} \mathrm{O}$ & Water & 950 \\
\hline $\mathrm{Total}_{2} \mathrm{Sample}^{2}$ & & $\mathbf{1 0 5 4 . 6}$ \\
\hline & & \\
\hline
\end{tabular}

(1b) The test samples were prepared by adding a known amount of a NIST calibrated "spike" solution (aqueous solution containing known quantities of ${ }^{57} \mathrm{Co},{ }^{60} \mathrm{Co},{ }^{90} \mathrm{Sr},{ }^{137} \mathrm{Cs},{ }^{210} \mathrm{~Pb},{ }^{210} \mathrm{Po},{ }^{226} \mathrm{Ra},{ }^{230} \mathrm{Th}$, ${ }^{234} \mathrm{U},{ }^{235} \mathrm{U},{ }^{238} \mathrm{U},{ }^{238} \mathrm{Pu},{ }^{240} \mathrm{Pu},{ }^{241} \mathrm{Am},{ }^{243} \mathrm{Cm}$ to the bottle with the urine matrix.

(2a) Solutions of tracers were prepared by gravimetric dilutions of NIST Standard Reference Material SRM's or NIST calibrated solutions. The dilution factors at each step were confirmed by radioactivity measurements.

(2b) The ${ }^{210}$ Po reference date was 12:00 EST, 26 August 2010, the date of measurement reported by the laboratory. 
Note: Half-life data are based mainly on DDEP-Working Group recommended values (see References). Uncertainties are quoted at the one-sigma level.

(4) The laboratory value represents the mean of five replicate measurements. The reported uncertainty was multiplied by a coverage factor of $\mathbf{k}=\mathbf{2}$.

(5) The Difference quoted is the difference between the NIST Value and Reported Value, expressed as a percent relative to the NIST Value.

(6) Test samples were prepared by gravimetric dilutions of NIST calibrated solutions and SRM's. These solutions and SRM's were calibrated using the following activity measurement methodologies:

$\begin{array}{ll}\text { a) } & \frac{\text { Nuclide }}{57} \mathrm{Co} \\ \text { b) } & { }^{60} \mathrm{Co} \\ \text { c) } & { }^{90} \mathrm{Sr} \\ \text { d) } & { }^{137} \mathrm{Cs} \\ & \\ \text { e) } & { }^{210} \mathrm{~Pb} \\ \text { f) } & { }^{230} \mathrm{Th} \\ \text { g) } & { }^{226} \mathrm{Ra} \\ \text { h) } & { }^{234} \mathrm{U},{ }^{235} \mathrm{U},{ }^{238} \mathrm{U} \\ \text { i) } & { }^{238} \mathrm{Pu} \\ \text { j) } & { }^{240} \mathrm{Pu} \\ & \\ \text { k) } & { }^{241} \mathrm{Am} \\ \text { l) } & { }^{243} \mathrm{Cm}\end{array}$

\section{Methodology} Pressurized " $4 \pi$ " $\gamma$ ionization chamber " $A$ " calibrated using a cobalt- 57 solution whose activity was determined by " $4 \pi$ " $-(\beta+\gamma)$ coincidence and anti-coincidence counting Pressurized " $4 \pi$ " $\gamma$ ionization chamber " $A$ " calibrated using a cobalt -60 solution whose activity was determined by " $4 \pi$ "- $(\beta+\gamma)$ coincidence and anti-coincidence counting NIST $4 \pi \beta$ liquid-scintillation counting system Pressurized " $4 \pi$ "- $\gamma$-ionization chamber " $A$ " calibrated using a cesium- 137 solution whose activity was determined by " $4 \pi$ "- $(\mathrm{e}+$ $\mathrm{X})-\gamma$-anti-coincidence counting Pressurized " $4 \pi$ " gamma ionization chamber " $\mathrm{A}$ " calibrated using a barium-133 solution whose number of cesium-137 atoms was determined by isotope-dilution mass spectrometry $4 \pi(\alpha+\beta)$ liquid-scintillation counting systems Two $4 \pi \alpha$ liquid scintillation counting systems Pressurized " $4 \pi$ " $\gamma$ ionization chamber " $A$ " Mass spectrometry, silicon surface barrier alpha-detection, and $4 \pi(\alpha+\beta)$ liquid-scintillation counting systems Two $4 \pi \alpha$ liquid scintillation counting systems NIST $0.1 \pi$ alpha defined solid angle counter with scintillation detector, two $4 \pi \alpha$ liquid scintillation counting systems, and a silicon surface barrier $\alpha$-spectrometry system $4 \pi \alpha$ liquid-scintillation counting system NIST " $0.8 \pi$ " alpha and " $0.1 \pi$ " alpha defined-solid-angle counters with scintillation detectors

(7) Summary of the reporting laboratory methodologies.

(8) ANSI N42.22 defines the acceptance criteria for verification testing by NIST as:

$$
\left|V_{R}-V_{N}\right|<3 * \sqrt{u_{c}^{2}(N)+u_{c}^{2}(R)}
$$

Where: $\quad V_{N}=$ NIST Value;

$\mathrm{V}_{\mathrm{R}}=$ Reported Value;

$\mathrm{u}_{\mathrm{c}}(\mathrm{N})=$ standard combine uncertainty of the NIST value, $\mathrm{V}_{\mathrm{N}}$; $\mathrm{u}_{\mathrm{c}}(\mathrm{R})=$ standard combine uncertainty of the Laboratory value, $\mathrm{V}_{\mathrm{R}}$; and

$$
\begin{aligned}
3 * \sqrt{u_{c}^{2}(N)+u_{c}^{2}(R)} & =\text { Traceability Limit (limit to which measurement traceability may be } \\
& \text { claimed with } 99 \% \text { confidence) }
\end{aligned}
$$

(9) ANSI N13.30 defines criteria for acceptable bias between -25 and +50 percent, and acceptable precision between -40 and +40 percent, 1 sigma total propagated uncertainty. 


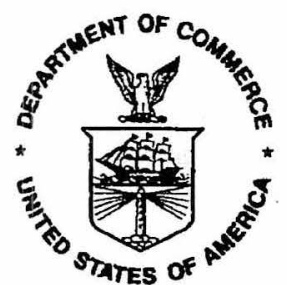

Test Identification:

Test Radionuclides:

Matrix Description:

Test Activity Range:

Reference Time:
U.S. DEPARTMENT OF COMMERCE

National Institute of Standards and Technology

Gaithersburg, MD

\section{REPORT OF TRACEABILITY}

\section{General Engineering Laboratories, LLC Charleston, South Carolina}

NRIP10-SU Set \#2

${ }^{57} \mathrm{Co},{ }^{60} \mathrm{Co},{ }^{90} \mathrm{Sr},{ }^{137} \mathrm{Cs},{ }^{210} \mathrm{~Pb},{ }^{210} \mathrm{Po},{ }^{226} \mathrm{Ra},{ }^{230} \mathrm{Th},{ }^{234} \mathrm{U},{ }^{235} \mathrm{U},{ }^{238} \mathrm{U},{ }^{238} \mathrm{Pu}$, ${ }^{240} \mathrm{Pu},{ }^{241} \mathrm{Am},{ }^{243} \mathrm{Cm}$, gross alpha, gross beta in acidified water

Synthetic Urine

$30 \mathrm{mBq}$ esample ${ }^{-1}$ to $300 \mathrm{mBq} \cdot \mathrm{sample}^{-1}$

12:00 EST, August 1, 2010

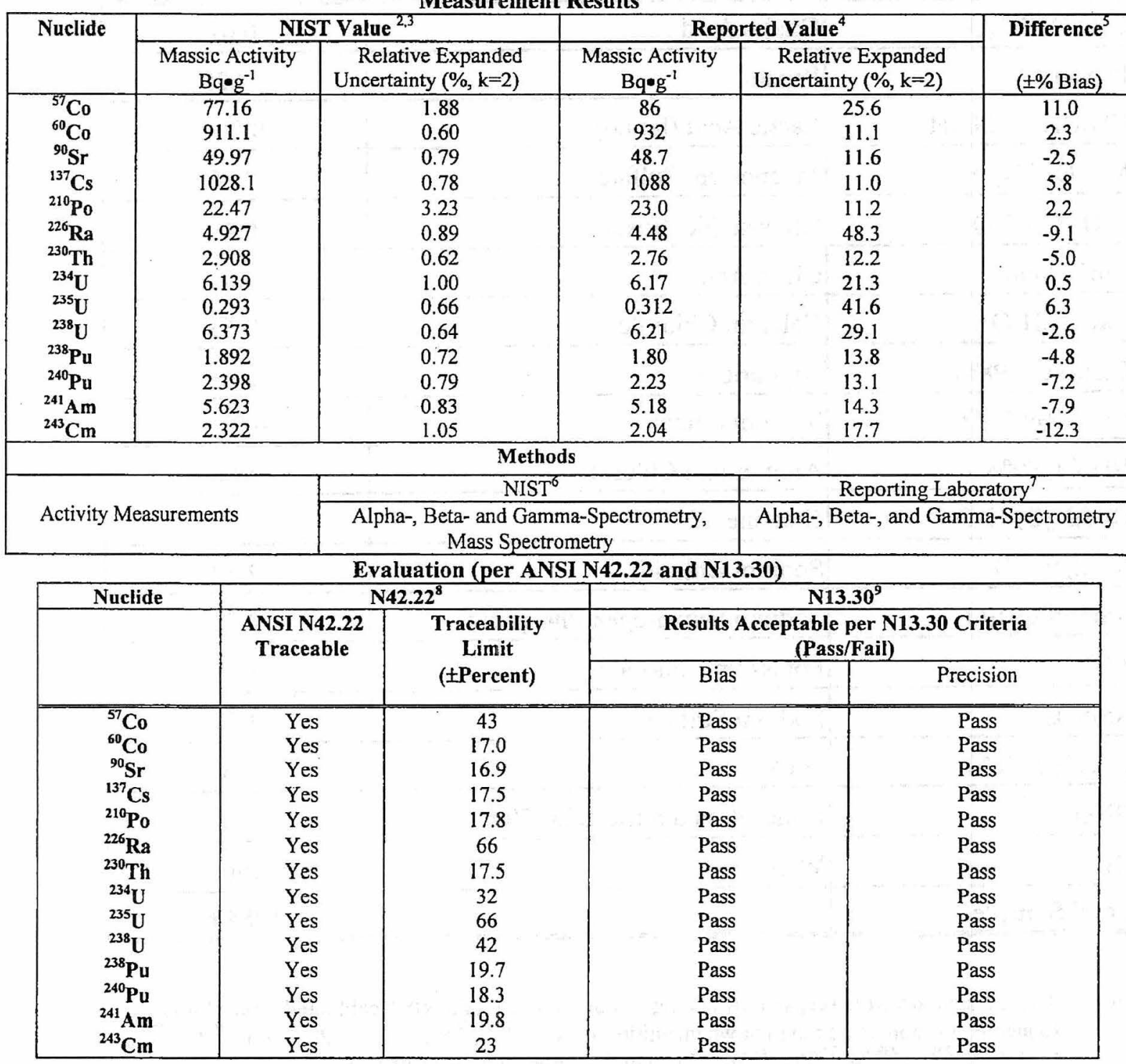

Samples Distributed

July 15,2010

Reporting Data Received September 14, 2010
For the Director

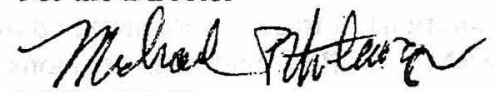

Michael P. Unterweger,

Group Leader

Radioactivity Group

Physical Measurement Laboratory

(Continued) 
(1a) Five test-samples and three (identical matrix) blanks were provided for this test. Each sample consisted of approximately 1000 or 100 grams of synthetic urine material contained in a 1-L or $125 \mathrm{~mL}$ size polyethylene bottle.

\section{Composition of the Synthetic Urine}

\begin{tabular}{|c|c|c|}
\hline & Reagent & $\begin{array}{c}\text { Weight/1L Sample } \\
\text { (g) }\end{array}$ \\
\hline $\mathrm{H}_{2} \mathrm{C}_{2} \mathrm{O}_{4} \cdot 2 \mathrm{H}_{2} \mathrm{O}$ & Oxalic Acid & 0.02 \\
\hline Pepsin & Pepsin & 0.029 \\
\hline $\mathrm{CH}_{3} \mathrm{CHOHCO}_{2} \mathrm{H}$ & Lactic Acid (liquid) & 0.094 \\
\hline $\mathrm{MgSO}_{4} \cdot 7 \mathrm{H}_{2} \mathrm{O}$ & Magnesium Sulfate & 0.46 \\
\hline $\mathrm{C}_{5} \mathrm{H}_{11} \mathrm{O}_{5} \mathrm{CHO}$ & Glucose (dextrose) & 0.48 \\
\hline Citric Acid & Citric Acid & 0.54 \\
\hline $\mathrm{CaCl}_{2} \cdot 2 \mathrm{H}_{2} \mathrm{O}$ & Calcium Chloride & 0.63 \\
\hline $\mathrm{C}_{9} \mathrm{H}_{9} \mathrm{NO}_{3}, 98 \%$ & Hippuric Acid & 0.63 \\
\hline $\mathrm{Na}_{2} \mathrm{SiO}_{3} \cdot 9 \mathrm{H}_{2} \mathrm{O}$ & Sodium Silicate & 0.071 \\
\hline $\mathrm{NH}_{4} \mathrm{Cl}, 99 \%$ & Ammonium Chloride & 1.06 \\
\hline $\mathrm{C}_{4} \mathrm{H}_{9} \mathrm{~N}_{3} \mathrm{O}_{2} \cdot \mathrm{H}_{2} \mathrm{O}$ & Creatine & 1.1 \\
\hline $\mathrm{NaCl}, 99+\%$ & Sodium Chloride & 2.32 \\
\hline $\mathrm{NaH}_{2} \mathrm{PO}_{4} \cdot \mathrm{H}_{2} \mathrm{O}$ & Sodium Dihydrogen Phosphate & 2.73 \\
\hline $\mathrm{KCl}$ & Potassium Chloride & 3.43 \\
\hline $\mathrm{Na}_{2} \mathrm{SO}_{4}$ & Sodium Sulfate & 4.31 \\
\hline $\mathrm{CH}_{4} \mathrm{~N}_{2} \mathrm{O}, 98 \%$ & Urea & 16 \\
\hline $\mathrm{HNO}_{3}$ & Concentrated nitric acid $(50 \mathrm{~mL})$ & 70.7 \\
\hline $\mathrm{H}_{2} \mathrm{O}$ & Water & 950 \\
\hline Total Sample & & 1054.6 \\
\hline
\end{tabular}

(1b) The test samples were prepared by adding a known amount of a NIST calibrated "spike" solution (aqueous solution containing known quantities of ${ }^{57} \mathrm{Co},{ }^{60} \mathrm{Co},{ }^{90} \mathrm{Sr},{ }^{137} \mathrm{Cs},{ }^{210} \mathrm{~Pb},{ }^{210} \mathrm{Po},{ }^{226} \mathrm{Ra},{ }^{230} \mathrm{Th}$, ${ }^{234} \mathrm{U},{ }^{235} \mathrm{U},{ }^{238} \mathrm{U},{ }^{238} \mathrm{Pu},{ }^{240} \mathrm{Pu},{ }^{241} \mathrm{Am},{ }^{243} \mathrm{Cm}$ to the bottle with the urine matrix.

(2a) Solutions of tracers were prepared by gravimetric dilutions of NIST Standard Reference Material SRM's or NIST calibrated solutions. The dilution factors at each step were confirmed by radioactivity measurements.

(2b) The ${ }^{210}$ Po reference date was 12:00 EST, 26 August 2010, the date of measurement reported by the laboratory. 
Note: Half-life data are based mainly on DDEP-Working Group recommended values (see References). Uncertainties are quoted at the one-sigma level.

(4) The laboratory value represents the mean of five replicate measurements. The reported uncertainty was multiplied by a coverage factor of $k=2$.

(5) The Difference quoted is the difference between the NIST Value and Reported Value, expressed as a percent relative to the NIST Value.

(6) Test samples were prepared by gravimetric dilutions of NIST calibrated solutions and SRM's. These solutions and SRM's were calibrated using the following activity measurement methodologies:
a) $\quad \frac{\text { Nuclide }}{{ }^{57} \mathrm{Co}}$
b) $\quad{ }^{60} \mathrm{Co}$
c) ${ }^{90} \mathrm{Sr}$
d) $\quad{ }^{137} \mathrm{Cs}$
e) $\quad{ }^{210} \mathrm{~Pb}$
g) $\quad{ }^{226} \mathrm{Ra}$
h) ${ }^{234} \mathrm{U},{ }^{235} \mathrm{U},{ }^{238} \mathrm{U}$
f) $\quad{ }^{230} \mathrm{Th}$
i) $\quad{ }^{238} \mathrm{Pu}$
Methodology
Pressurized " $4 \pi$ " $\gamma$ ionization chamber " $A$ " calibrated using a cobalt- 57 solution whose activity was determined by " $4 \pi$ "- $(\beta+\gamma)$ - coincidence and anti-coincidence counting Pressurized " $4 \pi$ " $\gamma$ ionization chamber " $A$ " calibrated using a cobalt- 60 solution whose activity was determined by " $4 \pi$ "- $(\beta+\gamma)-$ coincidence and anti-coincidence counting NIST $4 \pi \beta$ liquid-scintillation counting system Pressurized " $4 \pi$ "- $-\gamma$-ionization chamber " $A$ " calibrated using a cesium-137 solution whose activity was determined by " $4 \pi$ "-(e + $X)-\gamma$-anti-coincidence counting Pressurized " $4 \pi$ " gamma ionization chamber " $\mathrm{A}$ " calibrated using a barium-133 solution whose number of cesium-137 atoms was determined by isotope-dilution mass spectrometry $4 \pi(\alpha+\beta)$ liquid-scintillation counting systems Two $4 \pi \alpha$ liquid scintillation counting systems Pressurized " $4 \pi$ " $\gamma$ ionization chamber " $A$ " Mass spectrometry, silicon surface barrier alpha-detection, and $4 \pi(\alpha+\beta)$ liquid-scintillation counting systems Two $4 \pi \alpha$ liquid scintillation counting systems NIST $0.1 \pi$ alpha defined solid angle counter with scintillation detector, two $4 \pi \alpha$ liquid scintillation counting systems, and a silicon surface barrier $\alpha$-spectrometry system
k) $\quad{ }^{241} \mathrm{Am}$ $4 \pi \alpha$ liquid-scintillation counting system NIST " $0.8 \pi$ " alpha and " $0.1 \pi$ " alpha defined-solid-angle counters with scintillation detectors

(7) Summary of the reporting laboratory methodologies.

ANSI N42.22 defines the acceptance criteria for verification testing by NIST as:

$$
\left|V_{R}-V_{N}\right|<3 * \sqrt{u_{c}^{2}(N)+u_{c}^{2}(R)}
$$

$$
\begin{aligned}
& \text { Where: } \quad V_{N}=\text { NIST Value; } \\
& \mathrm{V}_{\mathrm{R}}=\text { Reported Value; } \\
& u_{c}(N)=\text { standard combine uncertainty of the NIST value, } V_{N} \text {; } \\
& \mathrm{u}_{\mathrm{c}}(\mathrm{R})=\text { standard combine uncertainty of the Laboratory value, } \mathrm{V}_{\mathrm{R}} \text {; and } \\
& 3 * \sqrt{u_{c}^{2}(N)+u_{c}^{2}(R)}=\text { Traceability Limit (limit to which measurement traceability may be } \\
& \text { claimed with } 99 \% \text { confidence) }
\end{aligned}
$$

(9) ANSI N13.30 defines criteria for acceptable bias between -25 and +50 percent, and acceptable precision between -40 and +40 percent, 1 sigma total propagated uncertainty. 



\section{DEPARTMENT OF ENERGY LABORATORY ACCREDITATION Program}

\section{Performance Evaluation Results}

\section{Session 13}

Synthetic Urine / Synthetic Fecal 


\section{DEPARTMENT OF ENERGY \\ LABORATORY ACCREDITATION Program}

\section{Performance Evaluation Results}

\section{Laboratory Summary Reports}




\section{DEPARTMENT OF ENERGY}

\section{LABORATORY ACCREDITATION PROGRAM}

\section{Summary Report}

\begin{tabular}{llccc}
\multicolumn{1}{c}{ Laboratory: LAB 2} & & Session: 0110 & \\
\multicolumn{1}{c}{ Matrix: } & SF & & & \\
RESL & & Mean Bias & St. Dev Bias & Pass / \\
LogNo & Radionuclide & $(\mathrm{Br}):$ & Fb) & Fail \\
DL423 & Am-241 & -0.015 & 0.028 & Pass \\
DL423 & Co-60 & 0.072 & 0.067 & Pass \\
DL423 & Cs-137 & 0.045 & 0.052 & Pass \\
DL423 & Pu-238 & -0.046 & 0.039 & Pass \\
DL423 & Pu-239 & -0.059 & 0.055 & Pass \\
DL423 & Sr-90 & -0.077 & 0.035 & Pass \\
DL423 & U-234 & -0.074 & 0.080 & Pass \\
DL423 & U-238 & -0.062 & 0.056 & Pass \\
DL424 & Np-237 & -0.035 & 0.033 & Pass \\
DL424 & Th-228 & -0.067 & 0.039 & Pass \\
DL424 & Th-230 & -0.015 & 0.069 & Pass \\
DL424 & Th-232 & -0.114 & 0.033 & Pass
\end{tabular}

Acceptance Criteria: $\quad-0.25=<\mathrm{Br}<=0.50 \quad \mathrm{Sb}=<0.4$ 


\section{DEPARTMENT OF ENERGY \\ LABORATORY ACCREDITATION PROGRAM \\ Summary Report}

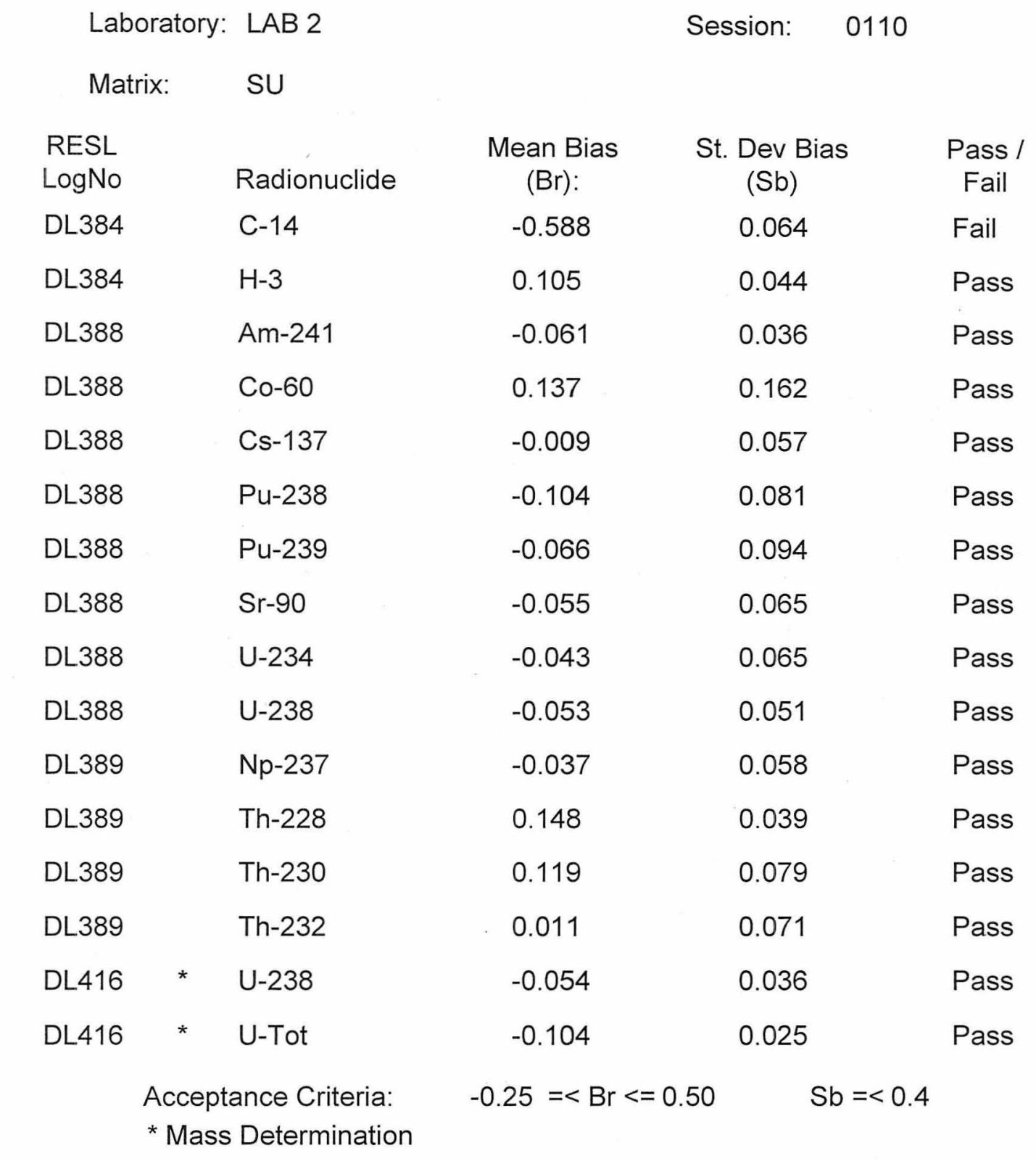

RADIOLOGICAL AND ENVIRONMENTAL SCIENCES LABORATORY 